\title{
ANÁLISE ENERGÉTICA DE DOIS SISTEMAS DE COLHEITA MECANIZADA DE EUCALIPTO
}

\author{
EZER DIAS DE OLIVEIRA JÚNIOR \\ Engenheiro Florestal
}

Orientador: Prof. Dr. FERNANDO SEIXAS

Tese apresentada à Escola Superior de Agricultura "Luiz de Queiroz", Universidade de São Paulo, para obtenção do título de Doutor em Recursos Florestais, com opção em Silvicultura e Manejo Florestal.

P I R A C I C A B A

Estado de São Paulo - Brasil

Março - 2005 


\section{ERRATA}

Oliveira Júnior, E.D. Análise energética de dois sistemas de colheita mecanizada de eucalipto. Piracicaba, 2005. 76p. : il. Tese (Doutorado em Recursos Florestais) - Escola Superior de Agricultura "Luiz de Queiroz", Universidade de São Paulo.

\begin{tabular}{|c|c|c|c|}
\hline Página & Linha & Onde se lê & Leia-se \\
\hline 14 & Figura 1 & Organograma dos fluxos & Fluxograma das entradas \\
\hline 37 & Figura 4 & Organograma do dispêndio & Fluxograma do dispêndio \\
\hline $\begin{array}{c}37 \\
\text { de energia }\end{array}$ & 8 & 3.2.1 Cálculos para conversão em energia & 3.2.1 Cálculos para conversão \\
\hline 37 & 11 & Buscou-se com isso validar & Buscou-se com isso aplicar \\
\hline 44 & Tabela 9 & $2^{\mathrm{a}}$ coluna, $31^{\mathrm{a}}$ linha $\mathrm{MJ}$ & suprimir a unidade. \\
\hline 46 & Tabela 11 & Investimento energético & Entradas energéticas \\
\hline 49 & Tabela 13 & Depreciação energética das máquinas & Potência das máquinas \\
\hline 49 & Tabela 14 & Investimento energético & Entradas energéticas \\
\hline 50 & Tabela 15 & Investimento energético & Entradas energéticas \\
\hline 51 & Tabela 17 & Investimento energético & Entradas energéticas \\
\hline
\end{tabular}


Dados Internacionais de Catalogação na Publicação (CIP) DIVISÃO DE BIBLIOTECA E DOCUMENTAÇĀO - ESALQ/USP

Oliveira Júnior, Ezer Dias de

Análise energética de dois sistemas de colheita mecanizada de eucalipto / Ezer Dias de Oliveira Júnior. - - Piracicaba, 2005.

76 p. : il.

Tese (Doutorado) - - Escola Superior de Agricultura Luiz de Queiroz, 2005.

Bibliografia.

1. Biomassa florestal 2. Colheita mecânica 3. Energia 4. Eucalipto 5. Extração de madeira 6. Manejo florestal 7. Mecanização florestal 8. Recurso energético 9. Transporte rodoviário l. Título

CDD 634.9734

"Permitida a cópia total ou parcial deste documento, desde que citada a fonte -0 autor 
"Em momentos de crise só a imaginação é mais importante que o conhecimento" Albert Einstein

À amada Luciana e Tobias Dedico

À Cleusa e Emanuela

Ofereço

"And we will all need to work together to ensure that we can meet our growing and changing energy needs" Karen de Segundo 


\section{AGRADECIMENTOS}

À Coordenação de Aperfeiçoamento Pessoal de nível Superior - CAPES pela bolsa concedida. Aos professores que acompanharam o desenvolvimento e tiveram a responsabilidade da participação no amadurecimento destas idéias, os quais servem-me de espelho na carreira acadêmica.

Prof. Dr. Fernando Seixas, orientador e exemplo de conduta e caráter a ser seguido,

Prof. Dr. Brito o qual me trata como colega do alto de sua experiência,

Prof. Dr. Maciel meu orientador na Feagri / Unicamp e especialista em biodiesel,

Prof. Dr. Milan que acompanha meu desenvolvimento desde o mestrado,

Prof. Dr. Kleber crítico desde o mestrado e grande colaborador,

Prof. Dr. Fenner que me apresentou à colheita e exploração,

Prof. Dr. Leonardo pela valiosa revisão e sugestões, e pela atual coordenação do Curso,

Prof. Luiz Carlos pela coordenação inicial do curso de pós graduação,

Aos professores com os quais tive a oportunidade de aprender em suas disciplinas, Prof. Dr. João Batista, Prof. Dr. Pogiani.

Aos amigos Everson, Gustavo e Maurício da Cenibra, Ao José De Sene e Cristiano Lopes da Duratex, Ao Amigo Eduardo Possamai da International Paper, Ao Rogério e Lauri da Ripasa e Ao Luiz Sérgio e Gláucio da Votorantim pela recepção e cooperação.

Aos colegas de curso pela troca de idéias e construção crítica do curso de pós, Ana Schilling, Elisa, Lia, Zé Márcio, Luiz Faria, Air Bag, Daniela, Lana. Israel Lima parceiro e amigão. Ao Ricardo pela DT. Ao Garmim, pela contribuição e implementação nos projetos do universo "fora de estrada". 
Ao Jefferson pelo apoio logístico, esclarecimentos e boa vontade em cada um desses dias, competente, dedicado e motociclista.

Aos amigos CB e Paulinha pelo empreendimento Copiadora "Luiz de Queiroz" e sua equipe, pois os maiores beneficiados, somos nós, a ESALQ.

Em especial ao Ricardo Rabatshi pela competência e pelo meu aprendizado obtido na edição final desta Tese.

Aos funcionários do departamento pelo convívio e excelência, Fátima, Margarete, Daniel, Rogério, Higor, Marcelo, Valdir, Evandro, Marialice Metzker Poggiani.

À Silvia Zinsly e Eliana pela revisão às normas de publicação e orientação, ao pessoal da catalogação bibliográfica e demais amigos da biblioteca.

Agradeço aos novos familiares pela compreensão e paciência. Em especial ao Prof. Lucio pela orientação e críticas ao trabalho, D. Rosa pela paciência e convívio, Lucio pela valiosa revisão do "summary", Cidinha por seu exemplo de dedicação, ao Roberto meu suplente nas tardes de sábado.

À minha irmã e minha Mãe, as quais esperam sempre um tempinho meu, pelo apoio, torcida e incentivo.

À minha esposa pela sociedade nesta empreitada, sua visão crítica e rigor me auxiliam no desenvolvimento profissional, seu carinho me abranda no emocional.

À Deus pelo empréstimo valioso concedido (Tobiah = aquele que agrada à Deus). 


\section{SUMÁRIO}

Página

LISTA DE FIGURAS .....................................................................................................ii

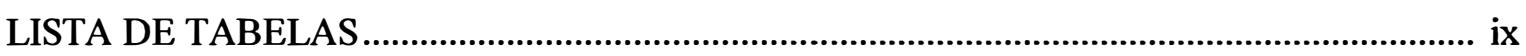

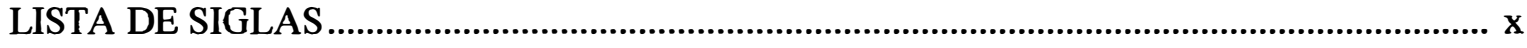

LISTA DE ABREVIATURAS E SÍMBOLOS ................................................................. xi

RESUMO

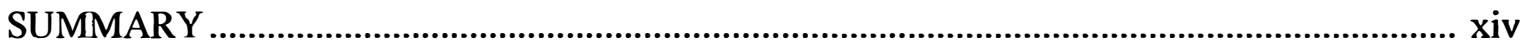

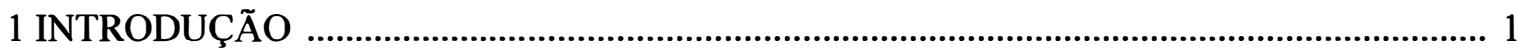

2 REVISÃO DE LITERATURA ………………………................................................. 3

2.1 Importância da biomassa.................................................................................................... 5

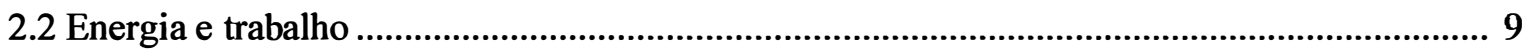

2.3 Eficiência energética....................................................................................................... 11

2.4 Produção de energia renovável ..................................................................................... 12

2.5 Entradas energéticas................................................................................................. 13

2.5.1 Colheita

2.5.2 Preparo do solo ................................................................................................. 18

2.5.3 Produção de mudas ...................................................................................................... 20

2.5.4 Transplante e condução............................................................................................... 21

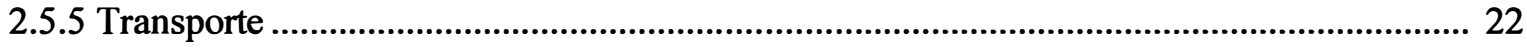

2.6 Conversão energética................................................................................................. 23

2.6.1 Energia direta .................................................................................................... 23

2.6.2 Energia indireta ................................................................................................... 26

2.7 Sistemas mecanizados de colheita e eficiência energética .................................................... 28 


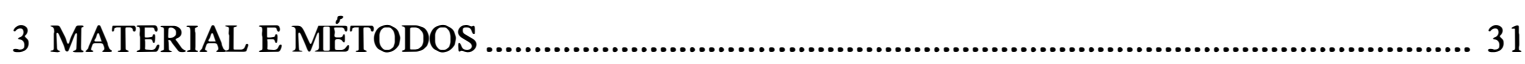

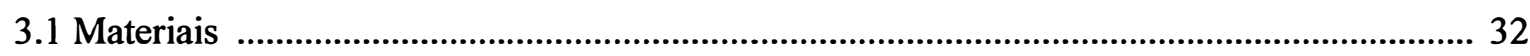

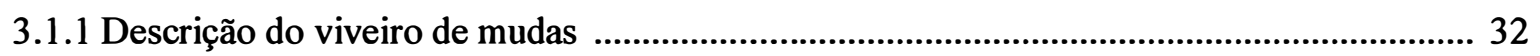

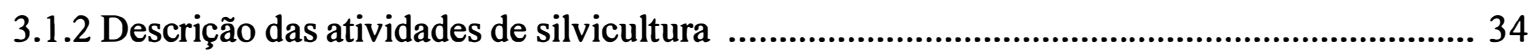

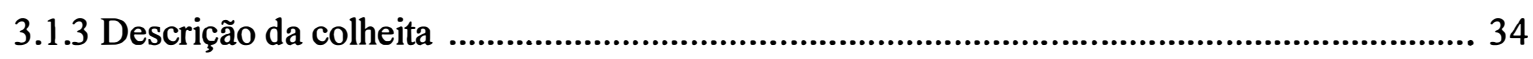

3.1.4 Descrição do transporte principal ..................................................................................... 36

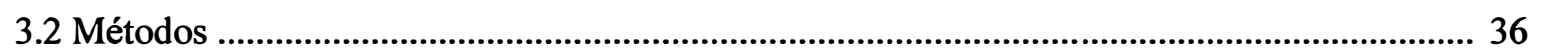

3.2.1 Cálculos para conversão em energia ........................................................................... 37

3.2.1.1 Método matricial ................................................................................................... 38

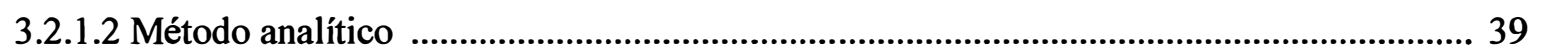

4 RESULTADOS ……………………....................................................................... 43

4.1 Cálculo analítico da atividade do viveiro ......................................................................... 43

4.2 Cálculo analítico das atividades de silvicultura ................................................................. 45

4.3 Cálculo matricial das atividades de silvicultura ..................................................................... 47

4.4 Cálculo analítico da atividade de colheita ......................................................................... 48

4.4.1 Sistema de toras curtas ............................................................................................... 49

4.4.2 Sistema de toras longas ........................................................................................... 50

4.5 Cálculo analítico da atividade de transporte ................................................................... 50

4.6 Cálculo matricial das atividades de colheita e transporte ...................................................... 52

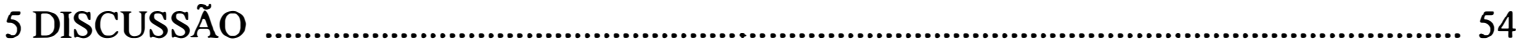

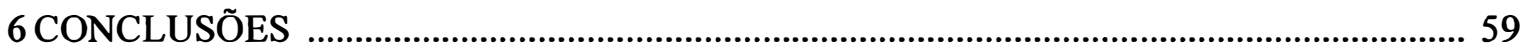

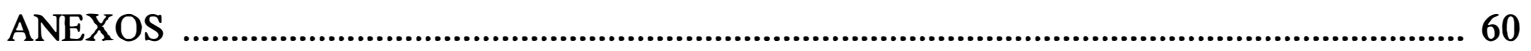

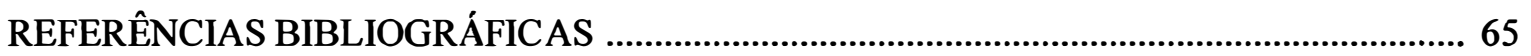

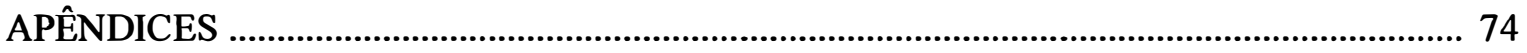




\section{LISTA DE FIGURAS}

Página

1 Organograma dos fluxos de energia na cadeia produtiva .............................................. 14

2 a Máquinas utilizadas na colheita mecanizada no sistema de toras curtas "harvester"............ 35

2 b Máquinas utilizadas na colheita mecanizada no sistema de toras curtas "forwarder" .......... 35

3 a Máquinas utilizadas na colheita mecanizada no sistema de toras longas "feller - buncher". 35

3 b Máquinas utilizadas na colheita mecanizada no sistema de toras longas "clambunk" ......... 35

3 c Máquinas utilizadas na colheita mecanizada no sistema de toras longas garra traçadora ..... 35

4 Organograma do dispêndio energético da operação .......................................................... 37

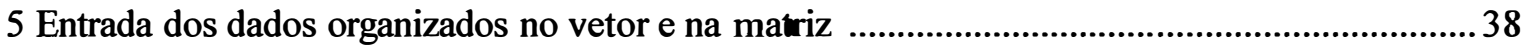

6 Cálculo matricial para as atividades de silvicultura ................................................... 47

7 Cálculo matricial do dispêndio energético nas atividades de colheita e transporte ................ 52 


\section{LISTA DE TABELAS}

Página

1 Potencial técnico de co - geração de energia em diferentes sistemas no Brasil ....................... 7

2 Usinas de energia elétrica que usam madeira como combustível ........................................ 9

3 Participação relativa das atividades florestais nas emissões de $\mathrm{CO}_{2}$ na Finlândia .................. 13

4 Balanço energético na atividade de colheita em função da produção florestal ...................... 15

5 Produtividade energética $\left(G J . h a^{-1}\right)$ da floresta em função do espaçamento aos 2,5 anos ........ 21

6 Classificação do esforço físico diário conforme atividade .................................................. 24

7 Valores médios mundiais de energia para produção e embalagem de nutrientes primários ..... 25

8 Distribuição média do consumo de energia direta por fonte ............................................... 27

9 Investimento energético na atividade de produção de mudas no viveiro .............................. 44

10 Descrição, consumo e desempenho das operações na atividade silvicultural ........................ 45

11 Investimento energético das atividades de silvicultura mecanizada ..................................46

12 Capacidade operacional e consumo das máquinas em cada sistema de colheita .................. 48

13 Depreciação energética das máquinas utilizadas na colheita mecanizada ............................ 49

14 Investimento energético na atividade de colheita no sistema de toras curtas ...................... 49

15 Investimento energético na atividade de colheita no sistema de toras longas ...................... 50

16 Desempenho das operações de transporte rodoviário e de cargas ...................................... 51

17 Investimento energético na carga e no transporte rodoviário ........................................... 51

18 Dispêndio energético final das operações em cada sistema de colheita ............................... 53

19 Súmula dos dispêndios energéticos das operações conforme o método de cálculo.................. 53 


\section{LISTA DE SIGLAS}

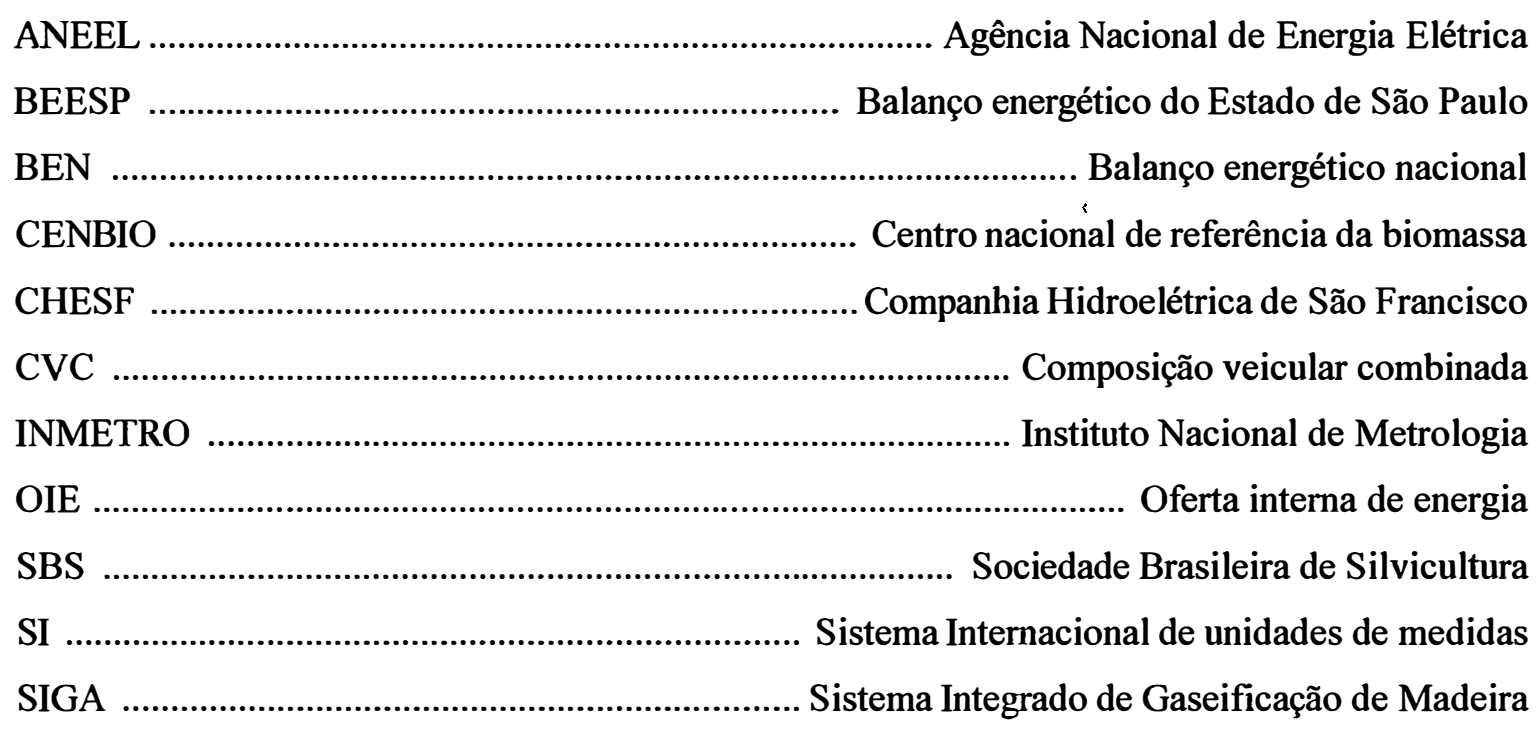




\section{LISTA DE ABREVIATURAS E SÍMBOLOS}

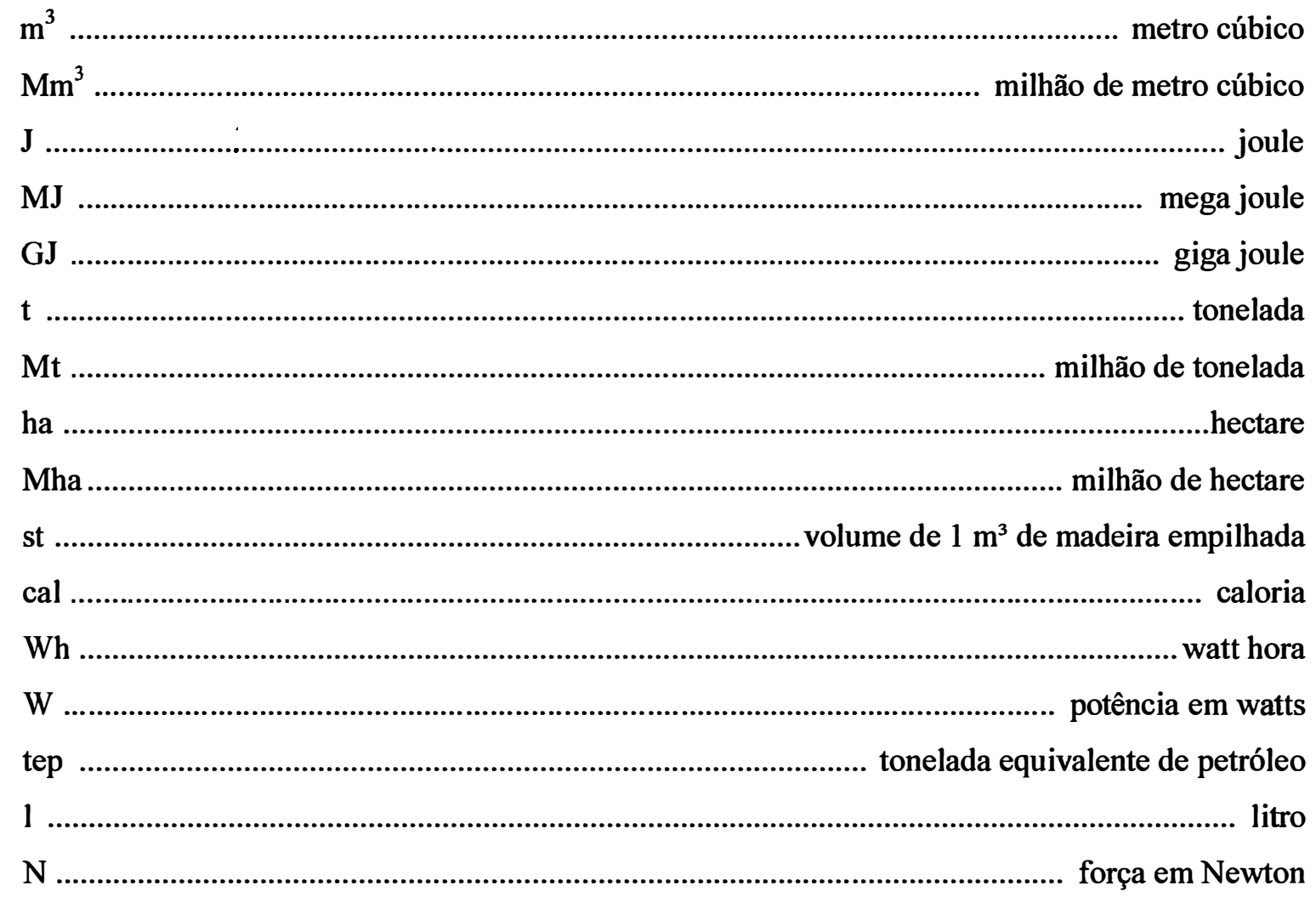




\title{
ANÁLISE ENERGÉTICA DE DOIS SISTEMAS DE COLHEITA MECANIZADA DE EUCALIPTO
}

\author{
Autor: EZER DIAS DE OLIVEIRA JÚNIOR \\ Orientador: Prof. Dr. FERNANDO SEIXAS
}

\section{RESUMO}

A colheita mecanizada é uma atividade com altos investimentos em máquinas, consumo de combustível e de lubrificante, representando dispêndio de energia. No caso da colheita mecanizada deve-se ponderar além da entrada de energia direta do combustível e do lubrificante, também a energia biológica do trabalho humano do operador e a energia indireta agregada pela utilização de máquinas e implementos. A mecanização das operações tem proporcionado aumento da capacidade operacional, no entanto, poucos trabalhos têm quantificado o dispêndio energético nas diversas atividades florestais quanto à utilização de máquinas e ao uso de insumos. A caracterização desse potencial técnico para a produção da madeira, bem como a forma de utilização de energia ao longo da cadeia produtiva, são de grande importância, pois existe grande dependência dos insumos proveniente da matriz fóssil. Nesta análise energética é contemplado o consumo de energia das operações florestais, sendo o enfoque principal a energia investida na atividade de colheita de um plantio florestal de eucalipto através de dois sistemas mecanizados, denominados de "toras curtas" e de "toras longas". Nesta análise foram simuladas as entradas de energia, classificadas e 
quantificadas conforme a fonte, considerando-se as características ponderais das máquinas e consumo de diesel em cada operação. Os cálculos de conversão foram realizados pelos métodos de equações e matrizes e as entradas de energia classificadas, conforme o fluxo, em energia direta e energia indireta. Foram analisadas também as atividades silviculturais e de transporte rodoviário com o objetivo de quantificar a relação de entradas totais de energia e o potencial energético existente na produção da madeira de eucalipto ao final do ciclo de sete anos. Pela análise energética do sistema quantificou-se o dispêndio de $17,99 \mathrm{GJ}^{-} \mathrm{ha}^{-1}$ pela silvicultura, $41,92 \mathrm{MJ} . \mathrm{m}^{-3}$ pelo transporte e na colheita, $36,73 \mathrm{MJ} . \mathrm{m}^{-3}$ no sistema de "toras curtas" e $41,53 \mathrm{MJ} . \mathrm{m}^{-3}$ no sistema de "toras longas". As atividades de colheita e transporte representaram em média $60 \%$ do dispêndio energético total. $\mathrm{O}$ potencial energético existente na madeira produzida ao final do ciclo foi em média 62 vezes maior que a energia investida. 


\title{
ENERGY ANALYSIS OF TWO MECHANIZED \\ SYSTEMS OF HARVESTING EUCALYPTUS
}

\author{
Author: EZER DIAS DE OLIVEIRA JÚNIOR \\ Adviser: Prof. Dr. FERNANDO SEIXAS
}

\section{SUMMARY}

Harvesting is an activity with high investments in machines, lubricant and fuel consumption. The total energy required to operate forestry machines includes not only direct energy of the fuel and the lubricant, but also indirect energy such as associated with manual labor and manufacturing the equipment. The mechanization of the harvesting process has increased the operational capacity, however few studies have focused on the energy consumption in the diverse forest activities regarding machine and inputs utilization in Brazil. This study quantifies the energy consumption in forestry operations, from seedling production to forest ransportation, evaluating in details, two harvesting systems: "cut to length" and "tree length". In this analysis all energy sources involved in the process were simulated, classified and quantified, taking into consideration machine productivity and diesel consumption in each operation. Making use of equation and matrix methods, the energy sources were classified as direct or indirect flow. The silviculture activities and road transportation were also analyzed with the objective of quantifying the relation between the total inputs of energy and the existing energy potential in the production of the eucalyptus wood after a seven year 
cycle. A systematic approach to forestry energy analysis requires all energy inputs of any significance to be included and accurately evaluated. The system energy analysis resulted 17.99GJ.ha ${ }^{-1}$ for silviculture, $41.92 \mathrm{MJ} . \mathrm{m}^{-3}$ for the transport, and 36.73 and 41.53MJ.m ${ }^{-3}$, respectively in the "cut to length" and "tree length" system. Harvesting and transportation accounted for $60 \%$ of the total energy consumption, and the energy yield was 62 times higher than the total invested energy. 


\section{INTRODUÇÃO}

A colheita mecanizada é uma atividade com altos investimentos em máquinas, consumo de combustível e de lubrificante. Essas entradas representam energia utilizada cuja quantidade pode ser estimada contabilizando-as conforme a fonte. No caso da colheita mecanizada deve-se ponderar além da entrada de energia direta do combustível e dos lubrificantes, também a energia biológica do trabalho humano do operador e a energia indireta pela utilização de máquinas e implementos.

A mecanização das operações tem proporcionado aumento da capacidade operacional, no entanto poucos trabalhos têm quantificado o dispêndio energético nas diversas atividades florestais quanto à utilização de máquinas e ao uso de insumos.

$\mathrm{Na}$ busca de ganhos de produção é necessário o controle dos recursos energéticos utilizados, determinando-se os investimentos em cada etapa do processo produtivo e assim identificar as de maior demanda de energia. A avaliação do sistema pode ser feita pela eficiência da intensidade energética ou pela relação entre entradas e saídas.

Pela análise energética do sistema é possível quantificar o acréscimo do dispêndio de energia ao final do ciclo e a energia agregada devido ao dimensionamento dos conjuntos mecanizados nas operações específicas de cada atividade. Esses dados podem subsidiar decisões na redução de custo com combustível pela correta manutenção e operação de máquinas e implementos.

O total de energia necessária para realização da atividade em cada sistema de colheita será diretamente proporcional ao número de operações envolvidas, considerando-se o desempenho e capacidade das máquinas em cada módulo. 
No Brasil, o suprimento de madeira para a indústria de base florestal tem sido feito basicamente por dois sistemas mecanizados de colheita. Um de corte no comprimento ("cut - to - length") denominado "toras curtas", cuja madeira é processada no local de corte, com módulo básico composto pelas máquinas "harvester" e "forwarder". O outro de fustes inteiros ("tree - length"), com a árvore sendo desgalhada e destopada no local de corte e o processamento da madeira sendo feito à margem do carreador, denominado "toras longas", composto por "feller - buncher", "skidder" e garra traçadora.

Tratando-se de sistemas totalmente mecanizados supõe-se que haja superávit entre consumo e produção de energia, mas com diferenças entre os sistemas quanto ao dispêndio de energia nas operações devido ao tipo de máquinas utilizadas nos módulos de colheita. Assim, como em termos econômicos, também em termos energéticos deve haver uma grande participação das operações de colheita em relação ao total das atividades na cadeia produtiva.

O objetivo principal deste rabalho foi analisar o consumo de energia investida nas operações dos sistemas de colheita mecanizada de "toras curtas" e de "toras longas", empregados em diferentes empresas florestais brasileiras e também identificar os fatores de maior influência em cada operação, estabelecer qual a relação do dispêndio energético da atividade de colheita em relação às demais atividades silviculturais e o potencial energético existente na madeira produzida ao final da rotação. 


\section{REVISÃO DE LITERATURA}

O Brasil destaca-se no cenário mundial pela importância da biomassa florestal e suas potencialidades com uma das mais altas taxas de produtividade na silvicultura, atingindo entre 40 e 50 metros cúbicos $\left(\mathrm{m}^{3}\right)$ de madeira por hectare ao ano, mais de 10 vezes superior à observada em países de clima temperado (Stape, 2003).

Atualmente, os plantios de florestas comerciais no Brasil cobrem uma área de 4,8 milhões de hectares. No Estado de São Paulo são 770 mil hectares de plantios (3,1\% da área). Desse montante o eucalipto responde por $79,4 \%$, o pinus, com $20,6 \%$ e outras madeiras com 2\% (Kronka et al., 2003).

Segundo a Sociedade Brasileira de Silvicultura - SBS (2004), o consumo anual de madeira industrial em toras no Brasil foi da ordem de 166,3 $\mathrm{Mm}^{3} \mathrm{em} 2001$. No Estado de São Paulo estima-se um consumo de $11 \mathrm{Mm}^{3}$ de biomassa florestal para fins energéticos, sendo o setor que mais sente a falta de madeira no mercado, pois o setor de celulose e papel, cujo consumo anual é da ordem de $8 \mathrm{Mm}^{3}$, têm fornecimento garantido pelos plantios próprios e contratos com terceiros.

Muitos estudos têm sido realizados sobre a viabilidade da floresta no suprimento de matéria prima para geração de energia em termelétricas, publicados pelo Centro Nacional de Referência da Biomassa - CENBIO (2003). No entanto, nenhum deles trata do dispêndio energético das operações mecanizadas ou os relaciona com a demanda de energia necessária para formar e colher uma floresta comercial de eucalipto.

A análise energética pode ser utilizada como importante ferramenta no planejamento como: i) critério para seleção de máquinas, ii) orientar diretrizes de atividades e operações nos povoamentos, iii) para a distribuição dos custos em sistemas em que alguns insumos têm usos múltiplos, como o caso da casca para energia ou como 
fonte de nutrientes, iv) para comparar diferentes sistemas mecanizados, como, por exemplo, cultivo mínimo e cultivo intensivo, v) para avaliar viabilidade na aplicação de novos insumos, como aplicação de resíduos industriais ou urbanos.

Segundo Ferreira (2000), a análise de energia na década de 70 orientou-se para o estudo da eficiência nos processos de produção, avaliação de tecnologias alternativas de energia primária, estimação das necessidades diretas e indiretas de energia das atividades de produção e do consumo e, principalmente, a diminuição no fornecimento dos insumos naturais que promovem o crescimento econômico.

De acordo com Serra et al. (1979), a mecanização das operações acentuou o uso da energia fóssil, em formas progressivamente sofisticadas, como conseqüência do planejamento e utilização de máquinas, fertilizantes e pesticidas, propiciando aumentos consideráveis na produtividade com o passar do tempo. $\mathrm{O}$ uso de maiores quantidades de insumos foi sendo agregado às práticas agrícolas e florestais, sendo que o retorno nem sempre aumentou na mesma proporção. Como exemplo, Loftness (1984) cita que os EUA, usando tecnologia moderna, investiam $64,8 \mathrm{GJ}^{-\mathrm{ha}^{-1}}$ na cultura do arroz obtendo uma produtividade de $5,8 \mathrm{t} \cdot \mathrm{ha}^{-1}\left(11,2 \mathrm{GJ} . \mathrm{t}^{-1}\right)$, enquanto que com tecnologia tradicional as Filipinas investiam $0,17 \mathrm{GJ} . \mathrm{ha}^{-1}$ com a produtividade de $1,25 \mathrm{t} \cdot \mathrm{ha}^{-1}\left(0,14 \mathrm{GJ} \cdot \mathrm{t}^{-1}\right)$. A razão desse aumento na energia investida no exemplo norte americano é decorrência da utilização de insumos (fertilizantes, agroquímicos) e da mecanização, enquanto que no caso filipino a baixa produtividade está diretamente ligada ao pequeno investimento energético. Assim, devem-se ponderar quais as necessidades de investimento e a extensão de área necessária para suprir o mercado e produzir alimentos.

A quantidade de energia usada nas operações agrícolas depende de vários fatores, não só da energia proveniente do combustível, mas também daquela agregada na fabricação e distribuição das máquinas, do óleo lubrificante e hidráulico, do trabalho humano entre outros (Bridges \& Smith, 1979; Fluck, 1985).

Bridges \& Smith (1979) desenvolveram um esquema de comparação da energia usada pelas diversas operações mecanizadas, onde foi possível utilizar os dados da bibliografia para analisar separadamente cada operação dentro do processo de produção agrícola. Sua avaliação baseou-se no consumo de combustível fóssil, energia devido ao 
trabalho, incluindo-se a energia agregada na fabricação, transporte, manutenção e reparos das máquinas, bem como a agregada nas construções, sementes, fertilizantes e outros insumos usados na operação.

\subsection{Importância da biomassa}

Segundo Stape (2003), a alta produtividade das florestas está diretamente relacionada à eficiência no uso de recursos naturais, como água, nutrientes do solo e exposição à luz, durante o crescimento da planta.

Para Nogueira (2002), o cenário futuro é de que os derivados de petróleo e gás natural continuem desempenhando um papel relevante na matriz energética. Especificamente quanto à demanda desses derivados, o contexto previsível para a indústria brasileira de petróleo nas próximas décadas pode ser considerado positivo e equilibrado. Evidentemente que um exercício de projeção de cenários energéticos com tal amplitude apresenta largas possibilidades de variação. $\mathrm{O}$ autor considera em particular as associadas aos câmbios tecnológicos e aos efeitos das demais fontes energéticas. Não obstante, mesmo frente a incertezas desta ordem e reconhecendo ainda o inevitável caráter não renovável das reservas de petróleo e gás natural, cabe construir uma perspectiva sustentável de longo prazo, onde o desenvolvimento de sistemas combinados com energia renovável seja possível e seguramente oportuno.

Brito (1997) enfatiza a importância da lenha na matriz energética do Brasil, cuja fonte renovável pode suprir a demanda em setores específicos como carvão para as indústrias de ferro-gusa e aço, além da geração de energia elétrica. $\mathrm{O}$ autor considera também necessários investimentos da ordem de US\$ 3,2 bilhões por ano para restabelecer a oferta de madeira e garantir o aumento da eficiência na produção energética.

As atuais tecnologias de conversão da lenha em combustíveis líquidos, sólidos e gasosos de alto valor agregado, têm grande interesse mundial e recebem importante quantia de recursos para suas pesquisas e desenvolvimentos. A gaseificação e a pirólise 
são processos termoquímicos mais eficientes, no entanto a combustão ou queima direta ainda é a forma mais radicional de uso da energia da lenha (Ferreira, 2000).

O setor residencial brasileiro consome $29 \%$ do total de lenha, destinados a coç̧ão dos alimentos nas regiões rurais. Uma família de oito pessoas necessita de aproximadamente $2 \mathrm{~m}^{3}$ de lenha por mês para preparar suas refeições. $O$ setor industrial vem em seguida com cerca de $23 \%$ do consumo. As principais indústrias consumidoras de lenha no país são alimentos e bebidas, cerâmicas e papel e celulose (BEN, 2003).

A substituição da lenha de mata nativa por lenha de reflorestamento vem crescendo a cada ano, sendo o eucalipto a principal árvore cultivada para este fim. $\mathrm{Na}$ produção de lenha para fins comerciais, uma parte da árvore (ponteiros, e galhos finos) é rejeitada constituindo os resíduos florestais. Além disso, algumas indústrias como serrarias e de móveis produzem resíduos industriais como: pontas de toras, costaneiras e serragem em diferentes tamanhos de partículas e densidade, que podem ter aproveitamento energético (CENBIO, 2003).

Segundo Brito (1999), a demanda de energia proveniente da madeira era de 90\% para 1,5 bilhão de pessoas no mundo. Para o Brasil de 1995 a madeira representava 27,4 giga toneladas equivalentes de petróleo - Gtep da matriz energética renovável do País, algo em torno de $23 \%$ do total das fontes renováveis.

De acordo com Kamimura (2001), os Estados de Minas Gerais e São Paulo apresentaram em 2000 o maior e menor consumo de lenha residencial per capita dos Estados estudados, cerca de $4853 \mathrm{MJ} \cdot \mathrm{hab}^{-1}$ e $373 \mathrm{MJ}^{-} \mathrm{hab}^{-1}$ respectivamente, uma diferença de 13 vezes. $\mathrm{O}$ autor argumenta que a lenha residencial no Brasil, na maioria das vezes, tem origem fora do processo econômico, ou seja, ocorre simples catação, mas sua avaliação tem fundamental importância por afetar o planejamento de todo o sistema energético.

Segundo o Balanço Energético Nacional - BEN (2003), a participação da lenha na oferta interna de energia em 2001 foi cerca de $11,5 \%$ da produção de energia primária. Atualmente essa participação gira em torno de $8 \%$, indicando uma menor atenção por parte das políticas energéticas quando se trata da biomassa na matriz renovável. A energia da biomassa no balanço inclui o bagaço de cana, a lenha, o carvão 
vegetal e o álcool. O consumo final de biomassa em 2001 foi de $53 \%$ no setor industrial, sendo que o setor de papel e celulose usou $10 \%$ desse montante, o que representou o segundo maior uso dentro do setor industrial, após o setor de bebidas e alimentos que usou $28 \%$.

O consumo específico de energia proveniente da lenha nas indústrias de celulose e papel é da ordem de $21,8 \mathrm{GJ} . \mathrm{t}^{-1}$ de produto (BEN, 2004). Soma-se a isso a energia de $0,4 \mathrm{GJ}$ da fase silvicultural (Ferreira, 1999) na produção de $4 \mathrm{~m}^{3}$ de madeira para cada tonelada de celulose, e ter-se-á o consumo específico do produto considerando-se todas as etapas da cadeia produtiva. Ou seja, a madeira representa apenas $1,8 \%$ do investimento energético.

A biomassa também tem importância para geração de eletricidade como demonstra a situação de empreendimentos termelétricos no Brasil na Tabela 1, de acordo com dados fornecidos pela Agência Nacional de Energia Elétrica - ANEEL (2003).

Tabela 1. Potencial técnico de co-geração de energia em diferentes sistemas no Brasil

\begin{tabular}{lc}
\hline \multicolumn{1}{c}{ Tipo de Combustível } & Potência (MW) \\
\hline Somente Bagaço de cana & 391 \\
Somente Biomassa & 83 \\
Biomassa e Bagaço de cana & 4,0 \\
Biomassa e Óleo combustível & 8,8 \\
Lenha picada & 5,3 \\
Licor negro & 310 \\
Licor negro e Biomassa & 143 \\
Lixo urbano & 26 \\
Lixo Urbano e Gás natural & 600 \\
Óleo combustível e Biomassa & 70 \\
\multicolumn{1}{c}{ TOTAL } & 1633,6 \\
\hline
\end{tabular}

Fonte: ANEEL (2003).

O bagaço de cana e o licor negro estão entre as fontes mais importantes, nos setores sucroalcooleiro e de papel e celulose respectivamente, além de diversos tipos de sistemas híbridos com combustíveis fósseis. No Plano Decenal de Expansão 2000/2009 o potencial técnico de co-geração nestes dois setores é estimado em $5.750 \mathrm{MW}$, com um potencial de mercado de pouco mais de $2.800 \mathrm{MW}$, em 2009 (BEN, 2004). 
Segundo a Companhia Hidroelétrica de São Francisco - CHESF (2003), foi desenvolvida tecnologia para implementar a participação da madeira na matriz renovável através do programa de gaseificação na Bahia. O Sistema Integrado de Gaseificação de Madeira - SIGA foi desenvolvido em conjunto com Eletrobrás, Shell e Ministério da Ciência e Tecnologia, planejado para produzir energia a partir da madeira de eucalipto numa usina de $32 \mathrm{MW}$.

Todas essas ações devem considerar o balanço energético da produção de madeira em todas as operações envolvidas conforme o sistema de colheita e máquinas utilizadas na atividade florestal, bem como a viabilidade de aproveitamento do resíduo. A manutenção do resíduo implica em aumento de custo para as operações da silvicultura. $\mathrm{O}$ resíduo pode ser vendido ou doado para quem faz dele carvão ou revende a quem o faz. Os trabalhos nessa linha de pesquisa estão bem adiantados na Finlândia.

Segundo Hakkila (2003), a Finlândia tem 20Mha de florestas produtivas com um incremento anual de $80 \mathrm{Mm}^{3}$. A produção per capita de madeira é maior que qualquer outro país da Europa e contabiliza-se o consumo de $15 \mathrm{~m}^{3}$ por pessoa, enquanto que nos demais países o consumo é da ordem de $0,8 \mathrm{~m}^{3}$. Na Finlândia apenas $10 \%$ da madeira são usados como lenha, sendo que a maior parte da energia provém dos resíduos das indústrias de base florestal. Apesar da eficiência tecnológica, uma parte considerável da matéria prima não é aproveitada no produto final e há perdas no processo. Cerca de $40 \%$ da madeira que entra no processo industrial têm potencial de serem usados como combustível e nenhum resíduo é desperdiçado. Do total de madeira produzido, $35 \mathrm{Mm}^{3}$ (46,5\%) são usados na produção de energia. Essa madeira usada como combustível responde por $20 \%$ da energia primária (73TWh) e $11 \%$ da energia elétrica.

Segundo dados da Agência Nacional de Energia Elétrica (ANEEL, 2003), no Brasil existem várias usinas que trabalham com subprodutos da madeira, como exemplificado na Tabela 2 a seguir. 
Tabela 2. Usinas de energia elétrica que usam madeira como combustível

\begin{tabular}{lclll}
\hline \multicolumn{1}{c}{ Usina } & $\begin{array}{c}\text { Potência } \\
(\mathbf{k W})\end{array}$ & \multicolumn{1}{c}{ Proprietário } & \multicolumn{1}{c}{ Município } & Combustível \\
& & & \\
\hline Castanha & 4.000 & Madeireira São Francisco & Canoinhas - SC & Cavacos \\
Pizzato & 2.000 & Pedro Pizzato Ltda & Gal. Carmeiro - PR & Cavacos \\
Rio Pardo & 4.500 & R. Pardo Papelões Ltda & Sta Rosa de Viterbo - SP & Cavacos \\
Ripasa & 15.000 & Ripasa S/A & Limeira-SP & Cavacos \\
Forjasul & 1.800 & Forjasul Ltda & Encruzilhada do Sul - RS & Serragem \\
\hline
\end{tabular}

Fonte: ANEEL (2003).

No Estado de São Paulo a utilização da madeira como fonte renovável tem sido discutida e, ao lado da indústria sucroalcoleira, as indústrias florestais também podem exercer papel fundamental. No entanto, segundo dados de Kronka et al. (2003), dos 25Mha de área do Estado, apenas 770.010 ha (3,1\%) são cultivados com florestas. $\mathrm{O}$ déficit para energia é da ordem de $5,7 \mathrm{Mm}^{3}$ anuais, o que representa a necessidade de plantar mais $287.000 \mathrm{ha}$, aumentar a produtividade das áreas já existentes e favorecer os plantios com fins energéticos onde haja maior concentração populacional, devido ao uso de carvão e de madeira para energia.

\subsection{Energia e trabalho}

Segundo o Balanço Energético do Estado de São Paulo - BEESP (2003), por razões históricas, cada unidade do Sistema Internacional (SI) está associada a alguma forma de energia. Assim, à caloria - cal se associa o calor (proveniente do petróleo, do carvão, da lenha), ao joule - $\mathbf{J}$ se associa a energia mecânica (de origem hidráulica, eólica etc.) ao watt hora - Wh se associa a eletricidade, de forma que qualquer que seja a unidade escolhida para se contabilizar um balanço de energia, surge imediatamente o problema de conversibilidade entre as diversas formas de energia.

Em alguns países, onde o petróleo representa o principal insumo na geração térmica e elétrica é comum o uso da unidade equivalente de petróleo - tep, uma unidade espúria fora do SI, mas que representa a quantidade de petróleo necessária para a realização das tarefas energéticas demandadas. 
No Brasil, onde a Oferta Interna de Energia - OIE é essencialmente hidráulica existem algumas distorções quando comparadas as fontes energéticas com a tep. Nesse caso, $1 \mathrm{kWh}$ de eletricidade corresponderia à quantidade de calor necessária para produzi-la $(13,1 \mathrm{GJ})$ e não ao seu equivalente calórico $(3,6 \mathrm{GJ})$. Além disso, o fator de equivalência para tep foi determinado considerando-se uma eficiência de apenas $27,5 \%$ na transformação do petróleo em energia elétrica, quando a média mundial encontra-se em torno de $35 \%$ a $40 \%$. A unidade quilocaloria (kcal) está associada à energia térmica ou calor, na qual qualquer energético pode ser convertido integralmente através do primeiro princípio da Termodinâmica, o que demonstra a existência de um denominador comum na representação contábil de um balanço envolvendo formas de energia com diferentes "qualidades" (BEESP, 2003).

De acordo com Instituto Nacional de Metrologia - INMETRO (2004), a unidade cal está fora do SI, mas temporariamente aceita, sendo o joule a unidade a ser adotada em todos os sistemas pra indicar as grandezas de trabalho, energia e quantidade de calor.

O fluxo de energia é dado pela razão do trabalho num período de tempo. Assim, a capacidade máxima de trabalho ou nível de potência que um cavalo pode manter é $0,746 \mathrm{~kW}, 10$ vezes maior que o trabalho humano. Um dia de trabalho de uma pessoa equivale à uma hora de trabalho do animal. Utilizando-se 3,8 1 de gasolina num trator por 15 minutos tem-se algo em torno de $8,8 \mathrm{kWh}$, cuja potência é maior que um cavalo trabalhando à sua capacidade máxima por $10 \mathrm{~h}$ ou o equivalente a três semanas de trabalho humano considerando-se 40h semanais (Pimentel \& Pimentel, 1996).

O comparativo da capacidade humana com a do animal, ou com as máquinas, nos dá a idéia de quanto de energia é necessário investir num sistema de produção agrícola ou florestal conforme a tecnologia empregada. $\mathrm{O}$ custo relativo do trabalho humano e do combustível fóssil afeta o custo do produto produzido. Essa comparação é importante e podem ser feitas entre dois ou mais sistemas de produção, conforme o grau de mecanização pretendido, potencializando as entradas de energia com investimentos em máquinas, adubação, irrigação, manejo e processamento. 


\subsection{Eficiência energética}

De acordo com Monteith (1980), o maior volume de madeira requer investimento proporcional de energia para a atividade de colheita utilizando-se sistemas mecanizados mais complexos, mas sem comprometer o balanço quanto às saídas e entradas energéticas. $\mathrm{O}$ balanço de energia para a atividade de colheita está associado ao tipo de máquinas utilizadas e em função da produtividade de madeira.

Segundo Ferreira (1999), um sistema de produção florestal pode ser interpretado do ponto de vista energético como de conversão da energia da radiação solar em energia de produtos, com a utilização de água, gás carbônico e de produtos semi-elaborados, como combustíveis, fertilizantes, pesticidas e sementes. Um dos insumos básicos é o combustível que, analogamente ao grau de mecanização, resulta na quantidade de energia investida na produção de madeira ao final do ciclo.

Pimentel \& Pimentel (1996) afirmaram que a energia solar recebida em regiões temperadas varia de 6,3 a $18,8 \mathrm{MJ} \cdot \mathrm{m}^{-2} \cdot \mathrm{dia}^{-1}$, ou seja, cada $\mathrm{mm}^{2}$ recebe diariamente $1,5 \mathrm{~J}$, o suficiente para aumentar a temperatura de $3,8 \mathrm{ml}$ de água em $1{ }^{\circ} \mathrm{C}$. $\mathrm{O}$ total aproveitado através da fotossíntese é algo em torno de $0,5 \%$ para o milho, $0,4 \%$ para a batata e $0,2 \%$ para o trigo, sendo que não há na bibliografia dados específicos para o eucalipto.

A eficiência de uso da água, se considerada, irá facilitar a conclusão. Lima (1993) afirma que o eucalipto produz de 2 a $3 \mathrm{~g}$ de biomassa por $\mathrm{kg}$ de $\mathrm{H}_{2} \mathrm{O}$ utilizada, enquanto que o milho produz 1,08 ; o feijão 0,50 e o trigo $0,98 \mathrm{~g} \cdot \mathrm{kg}^{-1}$.

De acordo com Goldemberg (1979), a energia absorvida pela biomassa é de $0,02 \%$ do total incidente em solo brasileiro, o equivalente a 60 usinas como a de Itaipu. Segundo o autor estima-se uma fixação de carbono na ordem de $33 \mathrm{Gt}_{\text {.ano }}{ }^{-1}$, considerando-se a energia produzida de 1,29PJ.ano ${ }^{-1}$, o equivalente a 40TW.

De acordo com Serra et al. (1979), a maior dificuldade para a obtenção de um indicador energético de uma dada cultura é a contabilidade da energia indireta contida nas máquinas e nos produtos químicos utilizados como insumos. A energia total contida num sistema de produção pode ser contabilizada de duas maneiras: uma pela análise de processos e outra pela matriz insumo - produto. Nessa última técnica contabiliza-se 
junto às indústrias, lavouras, comércio e outros, quais os bens utilizados como insumo e quais as formas de energia direta que são gastas na fabricação ou montagem de um produto. A eficiência de uso da energia pode ser avaliada de maneiras diretas ou indiretas das quais as mais utilizadas são: energia dos parâmetros, intensidade de energia, relação entre as entradas e saídas.

\subsection{Produção de energia renovável}

O potencial técnico para a produção da energia renovável, bem como a forma de utilização dessa energia ao longo das cadeias produtivas, são de grande importância, pois proporcionam um menor consumo de energia da matriz fóssil e conseqüentemente auxiliam na redução das emissões de carbono na atmosfera (Nogueira, 2002).

Segundo Helzel (1993), a energia necessária para produção agrícola em 1972 considerando-se todos os insumos mais embalagem e transporte, foi cerca de 3,5\% da energia comercial mundial. Desse total, $51 \%$ foram consumidos em operações mecanizadas, $45 \%$ foram investidos em fertilizantes químicos e apenas $2 \%$ na produção pela aplicação de pesticidas.

A estimativa de Börjesson (1996) é que os aumentos futuros na eficiência e no desenvolvimento tecnológico dobrarão as produtividades de energia líquida nas próximas duas décadas. $\mathrm{O}$ autor considerou um cenário de transição até 2015, partindose de um sistema baseado na matriz fóssil para um de biomassa renovável, e estimou o aumento da entrada de energia na produção e no transporte de biomassa em aproximadamente 30 a $45 \%$, tendo a redução da saída de energia líquida em aproximadamente $4 \%$.

Karjalainen \& Asikainen (1996) estudaram as emissões causadas pela utilização de máquinas nas atividades florestais da Finlândia cujos resultados são apresentados na Tabela 3. 
Tabela 3. Participação relativa das atividades florestais nas emissões de $\mathrm{CO}_{2}$ na Finlândia

\begin{tabular}{lc}
\hline \multicolumn{1}{c}{ Atividade florestal } & Participação relativa \\
\hline Transporte rodoviário & $57 \%$ \\
Transporte primário (extração) & $18 \%$ \\
Colheita & $13 \%$ \\
Implantação e manejo & $8 \%$ \\
Transporte de máquinas (frete) & $4 \%$ \\
\hline
\end{tabular}

Fonte: Karjalainen \& Asikainen (1996).

Ainda segundo os autores anteriormente citados, os efeitos das emissões equivalem, em termos de $\mathrm{CO}_{2}$, a $1,31 \mathrm{Mt}$ e $0,67 \mathrm{Mt}$ em 20 e 100 anos respectivamente. No entanto, essas emissões são pequenas se comparadas aos $30.300 \mathrm{Mt}$ de $\mathrm{CO}_{2}$ fixados na madeira colhida.

Scholz et al. (1998) analisaram o balanço energético na produção de combustíveis sólidos provenientes da produção agrícola e florestal em função da tecnologia empregada. Os resultados mostraram que as entradas são relativamente menores que as saídas de energia, pois cada unidade de energia investida pode retornar de 7 a 30 unidades na colheita, podendo atingir 50 unidades extras se considerados os sub produtos. A energia colhida foi termicamente livre de emissão adicional de $\mathrm{CO}_{2}$.

\subsection{Entradas energéticas}

Campos et al. (1998), classificaram as entradas possíveis de energia em dois fluxos, sendo um externo que corresponde à energia injetada e outro interno ou energia convertida dentro do sistema. $\mathrm{O}$ fluxo externo divide-se em:

- Energia direta: energia elétrica, energia biológica (trabalho humano ou animal, sementes, mudas e biomassa) e energia fóssil (combustíveis, lubrificantes, adubos, corretivos, pesticidas, pneus). 
- Energia indireta: energia agregada em bens de produção como imóveis e maquinário, denominada depreciação energética.

O fluxo interno divide-se em:

- Primário: energia contida nas fibras e resíduos

- Secundário: energia de transformação dentro do processo de produção

O fluxograma da Figura 1 resume o conceito proposto pelos autores.

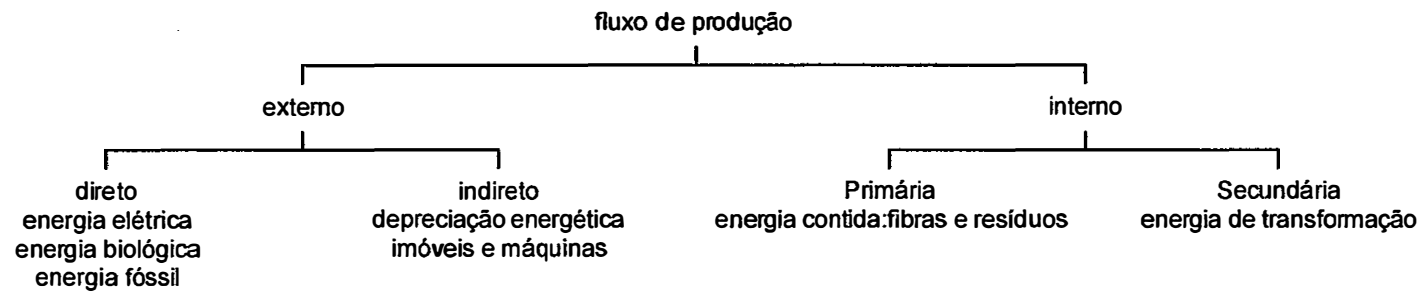

Figura 1 - Organograma dos fluxos de energia na cadeia produtiva

\subsubsection{Colheita}

Segundo Mattsson (1979), o consumo total de energia para se produzir florestas nas condições suecas aumentou em média de $70 \mathrm{MJ} . \mathrm{m}^{-3}$ em 1956 para $180 \mathrm{MJ}^{-3} \mathrm{~m}^{-3} \mathrm{em}$ 1972 devido à mecanização das operações. O autor comparou dois sistemas variando-se o grau de mecanização. Como resultado, contabilizou o dispêndio de $123,8 \mathrm{MJ}^{-\mathrm{m}^{-3}}$ no mecanizado e $58,3 \mathrm{MJ} \cdot \mathrm{m}^{-3}$ no semi - mecanizado. O consumo de combustível representou entre 5 a $10 \%$ dos custos totais de colheita de madeira.

A energia de produção e de consumo na colheita da madeira foi organizada em tabelas por Monteith (1980), para diversas condições e tipos de florestas dos EUA, com dados de 1977 (Tabela 4). O grau de tecnologia empregada na ocasião foi comparado com o dispêndio energético das operações revelando relação diretamente proporcional. 
Tabela 4. Balanço energético na atividade de colheita em função da produção florestal

\begin{tabular}{|c|c|c|c|c|c|c|c|c|c|}
\hline \multirow{2}{*}{$\begin{array}{c}\text { Produção } \\
\text { Investimentos }\end{array}$} & \multirow[b]{2}{*}{ un } & \multicolumn{2}{|c|}{$100 \mathrm{~m}^{3} \cdot \mathrm{ha}^{-1}$} & \multicolumn{2}{|c|}{$200 \mathrm{~m}^{3} \cdot \mathrm{ha}^{-1}$} & \multicolumn{2}{|c|}{$300 \mathrm{~m}^{3} \cdot \mathrm{ha}^{-1}$} & \multicolumn{2}{|c|}{$400 \mathrm{~m}^{3} \cdot \mathrm{ha}^{-1}$} \\
\hline & & un.ha ${ }^{-1}$ & MJ.ha' $^{-1}$ & un.ha $\mathrm{a}^{-1}$ & MJ.ha' & un.ha ${ }^{-1}$ & MJ.ha'1 & un.ha ${ }^{-1}$ & MJ.ha'-1 \\
\hline Trabalho & $\mathrm{h}$ & 34 & & 77 & & 100 & & 113 & \\
\hline Máquinas & $\mathrm{kg}$ & 11 & 829 & 31 & 2336 & 54 & 4069 & 73 & 5500 \\
\hline Ferramentas & $\mathrm{kg}$ & 0,19 & 14 & 0,55 & 41 & 0,94 & 71 & 1,28 & 96 \\
\hline Combustível & 1 & 167 & 7074 & 511 & 21394 & 840 & 35539 & 1143 & 48558 \\
\hline Subtotal & & & 7917 & & 23726 & & 39679 & & 54154 \\
\hline Madeira leve & $\mathbf{t}$ & 1300 & 23 & 3690 & 65 & 6380 & 112 & 8680 & \\
\hline Madeira dura & $\mathrm{t}$ & 16740 & 322 & 47420 & 913 & 82020 & 1578 & 111590 & 2147 \\
\hline Subtotal & $\mathrm{t}$ & 18040 & 345 & 51110 & 977 & 88400 & 1690 & 120270 & 2300 \\
\hline Saídas / entradas & & & 0,18 & & 0,17 & & 0,18 & & 0,18 \\
\hline Trabalho $\left(\mathrm{MJ} \cdot \mathrm{h}^{-1}\right)$ & & & 42,5 & & 53,1 & & 70,8 & & 85,2 \\
\hline
\end{tabular}

Fonte: Monteith (1980).

un.ha ${ }^{-1}=$ unidades por hectare

Nessas tabelas de balanço de energia constam dados que refletem as condições de relevo, eficiências operacionais e volume de resíduos particulares à realidade americana na década de 70. A energia investida de trabalho foi proporcional às horas de trabalho, mantendo-se constante a relação de entrada e saída de energia, indicando que foi necessário maior investimento energético para se obter maior produção de madeira, sem alterar o balanço final da atividade.

Serra et al. (1979) estudaram várias culturas no Brasil e, baseando-se em dados médios fornecidos pelas principais empresas do setor de produção de celulose e papel no Estado de São Paulo, verificaram que a energia investida na formação do povoamento de eucalipto com ciclos de 21 anos e colheitas a cada 7 anos, foi de 2,22GJ.ha ${ }^{-1}$.ano ${ }^{-1}$. Da energia investida na cultura, a implantação consumiu $60 \%$ e as conduções de rebrota $20 \%$ cada. A produtividade de madeira (massa seca) considerada foi de 11,8 tha $^{1}$.ano ${ }^{-1}$, o que representou um dispêndio de energia médio de $0,19 \mathrm{GJ} . \mathrm{t}^{-1}$ para a produção de madeira. 
Ferreira (1999) determinou o valor de $46,7 \mathrm{GJ} \cdot \mathrm{ha}^{-1}$ investidos da implantação à colheita, o equivalente a $0,2 \mathrm{GJ} . \mathrm{t}^{-1}$ resultando uma produção energética de $7.866 \mathrm{GJ} . \mathrm{t}^{-1}$ para o E.paniculata e $12.692 \mathrm{GJ} . \mathrm{t}^{-1}$ para o E.grandis.

Börjesson (1996) estudou a eficiência de produção para diferentes culturas agrícolas na Suécia, comparando-se sistemas baseados na matriz fóssil com aqueles baseados em biomassa renovável. Todos os cálculos das entradas de energia na produção de biomassa consideraram o ciclo total de combustíveis, incluindo-se as de fontes primárias necessárias para agregar energia a um determinado insumo, seja no aço usado nas máquinas ou no fertilizante. Assim, o autor exemplificou que para se produzir uma tonelada de aço são necessárias estas parcelas do total de energia: $15 \%$ do óleo combustível, $5 \%$ do gás natural, $60 \%$ do carvão e $20 \%$ da eletricidade. De modo geral, o autor afirma que nos atuais sistemas energéticos baseados na matriz fóssil, a energia usada na produção de óleo diesel, óleo combustível, gás natural e carvão corresponde à cerca de $10 \%$ do conteúdo energético do insumo produzido. Então, se considerados insumos indiretos os corretivos, fertilizantes e pesticidas, deve-se proceder ao cálculo da energia incorporada nesses insumos no que diz respeito à produção, embalagem e transporte. $\mathrm{O}$ autor verificou que a produtividade da energia líquida na produção de floresta de curta rotação de Salix spp foi de 160 a 170GJ.ha ${ }^{-1}$.ano ${ }^{-1}$. A entrada de energia por unidade de biomassa produzida foi mais baixa para os resíduos de Salix, o equivalente a 4 ou $5 \%$ da energia de saída.

Athanassiadis et al. (2002) calcularam para as condições suecas, a partir do consumo de combustível, que as entradas energéticas pela colheita de madeira foram de $82 \mathrm{MJ}^{-3} \mathrm{~m}^{-3}$. Desse total, $11 \%$ eram devidos à energia gasta no estágio de extração e refino do combustível. Os autores consideraram que $40 \%$ do investimento energético na atividade de colheita eram devidos ao uso de combustível fóssil.

Berg \& Lindholm (2004) inventariaram o uso da energia em operações florestais na Suécia entre 1996 e 1997, incluindo-se a produção de mudas, silvicultura, colheita e transporte principal até a indústria. $\mathrm{O}$ uso da energia foi de 150 a $200 \mathrm{MJ}^{-3} \mathrm{~m}^{-3}$ de madeira dependendo da região do país. Esse inventário demonstrou que o dispêndio energético do transporte principal foi maior que o verificado pelos autores na 
bibliografia em trabalhos anteriores. No contraste a isso, o dispêndio na colheita foi menor se comparada à década passada, possivelmente devido à melhor tecnologia e manejo.

Hetz (1992) buscou uma correlação entre tamanho das máquinas e o custo energético das operações mecanizadas na agricultura. Foram calculados as intensidades energéticas e os custos horários. Os resultados mostraram que os maiores custos de energia corresponderam à operação de preparo do solo e da colheita. Os menores custos corresponderam à operação de aplicação de fertilizantes. Os custos horários de energia foram dependentes do tamanho da máquina, mas os custos por área ou da massa processada foram independentes.

Bridges \& Smith (1979) também verificaram que o tamanho e a potência da máquina não influenciaram na demanda de energia na operação, não havendo relação entre tamanho de máquina com consumo de energia, a não ser por aquela agregada na fabricação e manutenção, mas de forma não significativa. Os autores compararam os dispêndios energéticos de duas colhedoras de cereais nas mesmas condições, sendo uma com potência de $52,2 \mathrm{~kW}$ e plataforma de $3,96 \mathrm{~m}$ de largura e outra de $74,6 \mathrm{~kW}$ e $4,38 \mathrm{~m}$, ambas operando a $4,38 \mathrm{~km} \cdot \mathrm{h}^{-1}$ a uma eficiência de campo de $70 \%$. As entradas de energia foram classificadas como: a) da fabricação, transporte e manutenções; b) combustível e c) trabalho humano. Os resultados foram $637,7 \mathrm{MJ}^{-h^{-1}}$ utilizando-se a colhedora de $52,2 \mathrm{~kW}$ de potência e $635,2 \mathrm{MJ}^{-h^{-1}}{ }^{-1}$ utilizando-se a colhedora de $74,6 \mathrm{~kW}$.

Para as atividades do setor florestal brasileiro foram verificados trabalhos de menor magnitude, alguns dos quais não tratam das operações de colheita e apenas contabilizam a silvicultura em três ciclos de rotação e operações semi mecanizadas, cuja produção de madeira foi de 11,8 t.ha $^{-1}$ (Serra et al., 1978 e Serra et al., 1979).

Damen (2001) estimou para as condições brasileiras, o dispêndio energético com base no diesel gasto por hectare nas atividades de silvicultura e por tonelada de madeira na atividade de colheita, simulando os dados, com valores de 1996, voltados à produção de eucalipto para o setor de celulose e papel. As entradas de energia para o módulo de colheita mecanizada, com feller, skidder e traçador, foram aproximadamente 
$123 \mathrm{MJ} . \mathrm{t}^{-1}$. O autor considerou o custo de colheita em US\$8.11 por tonelada seca de madeira, calculando-se custo energético de US\$1.08.GJ ${ }^{-1}$.

\subsubsection{Preparo do solo}

Segundo Lanças (2002), o preparo do solo é uma das operações de maior consumo de energia na silvicultura. Dentre as formas de se minimizar a energia estão: a utilização de técnicas de sistemas de cultivo mínimo ou reduzido, de operações conjugadas e melhoria na eficiência das operações com menores perdas de tempo em atividades. Além da avaliação do desempenho das máquinas, buscando-se minimizar os custos energéticos, é importante também a análise dos impactos causados pelo tamanho das máquinas. $\mathrm{O}$ autor, no entanto, não cita a ordem de grandeza dessa maximização dos resultados operacionais. A constatação matemática que o autor enfatizou refere-se ao aumento da capacidade operacional, pois sendo produto da largura da faixa de trabalho pela velocidade, a utilização de conjuntos maiores resulta numa maior eficiência, numa análise simplificada de minimizar custos operacionais e racionalizar o consumo energético das operações.

Gonçalves (2004) afirma que a mecanização e automação das práticas silviculturais é uma tendência crescente, visando a melhoria da qualidade e aumento da capacidade operacional cuja demanda está cada vez mais específica às práticas e às condições ambientais. $\mathrm{O}$ autor observa que tem sido comum o uso de tratores de maior potência aptos a operar nas condições severas do manejo de resíduos vegetais mais lenhosos. $\mathrm{O}$ autor alerta para a deficiente manutenção periódica dos implementos de preparo do solo comumente observada na prática, a qual ocasiona desperdício de insumos, diminuição do desempenho operacional e aumento do consumo de energia.

A eficiência de aproveitamento da potência de um trator é bem conhecida, existindo perdas na ordem de $17 \%$ no sistema de transmissão e de $23 \%$ na interface solo / pneu (Milan \& Molin, 2002). É evidente que no trator existem recursos técnicos que aumentam essa eficiência, dentre elas tração nos quatro rodados e uso de esteiras ao 
invés de pneus. Mas, os estudos são pouco avançados com relação a sua eficiência energética.

Uma estimativa de maior exatidão, melhor que o simples dado de consumo de combustível, é o desempenho do implemento analisado independentemente do trator que o traciona, como apresentado na equação 1 (Maciel, 2000).

$$
P=F^{*} V
$$

$\mathrm{P}=$ potencia requerida $(\mathrm{kW})$

$\mathrm{F}=$ força necessária $(\mathrm{kN})$

$\mathrm{V}=$ velocidade de operação $\left(\mathrm{m} . \mathrm{s}^{-1}\right)$

A potência necessária na barra de tração pode ser calculada reescrevendo-se a equação 1 , anteriormente citada, como na equação 2 a seguir.

$$
P_{B T}=\frac{F_{T} \cdot V_{D}}{3600}
$$

$\mathrm{P}_{\mathrm{BT}}=$ potência na barra de tração $(\mathrm{kW})$

$\mathrm{F}_{\mathrm{T}}=$ força de tração $(\mathrm{kN})$

$\mathrm{V}_{\mathrm{D}}=$ velocidade de deslocamento $\left(\mathrm{km} \cdot \mathrm{h}^{-1}\right)$

Bentivenha (2001) verificou que na operação de escarificação, sulcos rasos, com até $0,2 \mathrm{~m}$, tiveram menor gasto de energia sem haver diferenças na produção da floresta ao final do ciclo, sendo apenas detectadas diferenças até os 24 meses pós plantio. De acordo com Gonçalves et al. (2002), o crescimento inicial estimulado por maior volume de solo mobilizado pode ser considerável se analisado pela menor demanda de operações no controle das plantas invasoras.

Sasaki (2000) estudou a diferença para a profundidade efetiva de trabalho e a área de solo mobilizado, verificando que a haste reta - inclinada apresentou os melhores resultados quanto a demanda por força de tração e desempenho operacional. As ponteiras com asa exigiram cerca de $20 \%$ a mais de força de tração, $22 \%$ menos resistência específica operacional e mobilizaram $20 \%$ mais solo do que as ponteiras sem 
asa. Com o aumento da profundidade de trabalho, de 20 para $40 \mathrm{~cm}$, houve incremento da força de tração, da potência na barra de tração e da patinagem.

Milan \& Molin (2002), afirmam que na estimativa da ASAE para o cálculo de potência necessária para um determinado implemento existem variações de até $50 \%$. Ribeiro \& Ramos Jr (1995), verificaram que a mudança no sistema de engate do implemento do $3^{\circ}$ ponto para o de arraste resultou em melhora na qualidade da operação quanto à profundidade do preparo e permitiu a utilização de trator de menor potência de $95,6$ para $66,2 \mathrm{~kW}$ (130 para $90 \mathrm{HP})$.

\subsubsection{Produção de mudas}

Seixas (1991) estudou o investimento energético na atividade de colheita manual de sementes de eucalipto, e verificou como maior dispêndio a operação de coleta envolvendo escaladas em árvores matrizes e pré beneficiamento, alternando-se tempos de descanso. O consumo energético médio nessa atividade foi de $34 \mathrm{~kJ} \cdot \mathrm{min}^{-1} \mathrm{e}$ contabilizou a produção de $5 \mathrm{~kg}$ de sementes num dia de trabalho, cujo tempo efetivo foi 5,8h. A atividade foi considerada super pesada com intensidade energética de 2,37MJ. $\mathrm{kg}^{-1}$ da semente colhida.

A energia embutida na muda, além da agregada pela colheita da semente, envolve também a do sistema de produção e tecnologia empregada no viveiro, tais como infra-estrutura, tipo de propagação (semente ou estacas), adubações, tempo de permanência das mudas e distância de transporte.

Suiter Filho et al. (1982) determinaram o valor médio de $87,2 \mathrm{MJ} \mathrm{ha}^{-1}$ na produção de mudas de eucalipto, considerando-se apenas o consumo de combustível nas operações dos seguintes equipamentos: moto - bomba para irrigação, pulverizador costal motorizado, trator de esteira para retirada de terra do barranco e caminhões para transportes diversos.

Damen (2001) utilizou em seus cálculos de consumo de energia na produção de mudas de eucalipto no Brasil o mesmo valor de $300 \mathrm{MJ}^{-h^{-1}} \mathrm{ano}^{-1}$ da produção de sementes nas culturas agrícolas da Europa considerado por Biewinga (1996). 


\subsubsection{Transplante e condução}

Suiter Filho et al. (1982) computaram os dados de consumo de energia na implantação de floresta de eucalipto para produção de carvão vegetal e concluíram que o balanço de energia era positivo e as operações de transplante e condução do plantio tiveram um consumo médio de $4.138 \mathrm{MJ}^{-} \mathrm{ha}^{-1}$, cerca de $8 \%$ do total da atividade.

Segundo Helsel (1993), os pesticidas representam um grande dispêndio energético na fase de condução de uma cultura, pois mesmo aplicados em pequena quantidade em termos absolutos, relativamente há mais energia agregada por esse insumo do que em qualquer outro. Em média os pesticidas requerem de 4 a 5 vezes mais energia por unidade de massa para serem produzidos, se comparado aos fertilizantes nitrogenados.

$\mathrm{O}$ balanço de energia na fase de silvicultura pode ser otimizado se considerada a produtividade energética do povoamento florestal a qual está em função do espaçamento e da espécie plantada (Tabela 5). O poder calorífico dos resíduos pode ser contabilizado, devendo-se levar em conta a composição do material remanescente do sistema de colheita adotado. Na Tabela 5 verifica-se que o maior potencial de produção energética foi do Eucalyptus urophylla no espaçamento de 2,0 x 1,5m com cerca de 321,6GJ.ha ${ }^{-1}$.ano ${ }^{-1}$ (Brito et al.,1979; Brito, 1983).

Tabela 5. Produtividade energética (GJ.ha $\left.{ }^{-1}\right)$ da floresta em função do espaçamento aos 2,5 anos

\begin{tabular}{lcccccccc}
\hline \multicolumn{1}{c}{ Espécie } & Espaçamento & Lenho & Casca & Subtotal & Galhos & Folhas & Subtotal & Total \\
\hline E. saligna & $1,0 \times 1,5 \mathrm{~m}$ & 206 & 30 & 235 & 32 & 96 & 128 & 363 \\
E. urophylla & $1,0 \times 1,5 \mathrm{~m}$ & 323 & 40 & 362 & 51 & 70 & 120 & 483 \\
E. grandis & $1,0 \times 1,5 \mathrm{~m}$ & 132 & 30 & 261 & 18 & 70 & 88 & 349 \\
E. saligna & $2,0 \times 1,5 \mathrm{~m}$ & 170 & 32 & 202 & 44 & 96 & 140 & 342 \\
E. urophylla & $2,0 \times 1,5 \mathrm{~m}$ & 464 & 63 & 527 & 138 & 129 & 267 & 794 \\
E. grandis & $2,0 \times 1,5 \mathrm{~m}$ & 261 & 39 & 299 & 37 & 106 & 143 & 442 \\
E. saligna & $3,0 \times 1,5 \mathrm{~m}$ & 217 & 34 & 251 & 40 & 92 & 132 & 384 \\
E. urophylla & $3,0 \times 1,5 \mathrm{~m}$ & 292 & 45 & 337 & 111 & 95 & 206 & 543 \\
E. grandis & $3,0 \times 1,5 \mathrm{~m}$ & 315 & 46 & 360 & 86 & 109 & 195 & 556 \\
\hline
\end{tabular}

Fonte: adaptado de Brito (1983). 
Börjesson (1996) estimou o consumo médio dos combustíveis fósseis de acordo com a demanda tecnológica e o custo energético da produção de biomassa para os anos de 1996 e 2015. O resultado da produtividade energética líquida em 1996 para a floresta de Salix foi de 172 GJ.ha ${ }^{-1}$.ano ${ }^{-1}$, cerca de 21 vezes a energia investida. Na estimativa para o ano de 2015 essa produtividade aumentaria para $322 \mathrm{GJ} \mathrm{ha}^{-1}$.ano ${ }^{-1}$, cerca de 36 mais que o investido na fase silvicultural. Pela análise de sensibilidade, $o$ autor concluiu que a produtividade energética líquida é diretamente proporcional aos ganhos de produtividade da floresta e indiferente ao investimento energético nos insumos. Nesses últimos, a alteração em $50 \%$ da entrada de energia alterou apenas de 3 a $4 \%$ da produtividade energética líquida da cultura.

\subsubsection{Transporte}

Quanto à energia gasta no transporte a Saab - Scania (1998) define o aproveitamento do combustível em veículos de transporte como sendo expresso pelo produto entre a carga útil transportada e a distância percorrida pelo consumo de combustível, cuja unidade mais usual é t.km.1 ${ }^{-1}$.

Börjesson (1996) estudou as distâncias de transporte viável para diversas culturas, sendo que os cavacos de madeira de Salix podem ser transportados por caminhão por até 250 quilômetros, antes que a energia do transporte seja igual à energia da produção dos cavacos. As distâncias correspondentes para o trator, o trem e o barco (transporte litoral) foram aproximadamente 100,500 e 1000 quilômetros, respectivamente.

Damen (2001) em seu estudo de caso considerou a distância média de ransporte em $21,4 \mathrm{~km}$ assumindo-se as mesmas características de pavimentos de estradas do setor sucroalcoleiro. A energia gasta foi calculada a partir de dados médios da

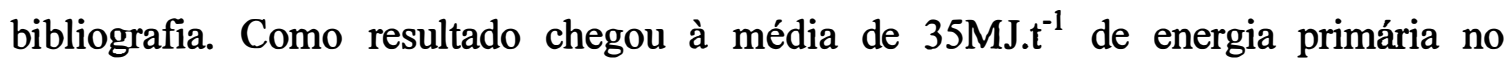
transporte, equivalente a $1,0 \mathrm{GJ} . \mathrm{ha}^{-1}$ se considerada a produtividade da floresta. 


\subsection{Conversão energética}

Serra et al. (1979) afirmam que para apresentar a matriz energética é necessário determinar o conteúdo energético de vários componentes tais como: mão de obra, tratores, máquinas, implementos, combustível, fertilizantes, agroquímicos, mudas e óleos lubrificantes. Vários métodos de análise energética têm sido propostos e todos convergem para a agregação de energia contabilizando-se as entradas e saídas de energia de acordo com as fontes dependendo do objetivo da análise (Pimentel \& Pimentel, 1996).

Fluck (1985) substituiu a análise estatística pela agregação total de energia sendo necessário haver exatidão nas entradas energéticas a serem consideradas.

\subsubsection{Energia Direta}

a) Mão de obra

Segundo Campos et al. (1998), o trabalho pode ser considerado como fonte de energia biológica se consideradas as horas empregadas em cada atividade. De acordo com Serra et al. (1978) o consumo energético do trabalho humano tem proximidade com os valores energéticos de máquinas e implementos que o substituem, algo em torno de $2,2 \mathrm{MJ} \cdot \mathrm{h}^{-1}$.

Ulbanere (1988) convencionou não contabilizar a energia do trabalho humano nem a energia das entradas às forças de trabalho, pois no caso de processos produtivos em sistemas mecanizados essa parcela não é significativa na análise energética. Evidente que é importante considerá-la em processos nos quais a força humana e a de animais sejam bastante utilizadas, ou ainda quando se for traçar comparativos entre processos em países desenvolvidos com aqueles em desenvolvimento. Ainda segundo o autor, o fator limitante nas relações trabalhistas é o salário e não a energia.

Sartori \& Basta (1999) adotaram o valor de $1,3 \mathrm{MJ} \cdot \mathrm{h}^{-1}$ para o trabalho humano por ser o mais próximo para a realidade no setor sucroalcoleiro. 
De acordo com Seixas (1991), a energia gasta para se realizar uma tarefa é denominada energia de wabalho (work joule) e pode ser estimada medindo-se o consumo de oxigênio $\left(\mathrm{O}_{2}\right)$. Cada litro de $\mathrm{O}_{2}$ consumido pelo corpo é equivalente a 20,1 J. A medição é feita pela diferença do teor de $\mathrm{O}_{2}$ do ar atmosférico e do exalado, multiplicado pelo volume de ar exalado. $\mathrm{O}$ grau de esforço físico está em função da energia gasta, do número de músculos envolvidos e a proporção solicitada de modo estático. As atividades podem ser classificadas pela carga de trabalho como mostrado na Tabela 6.

Tabela 6. Classificação do esforço físico diário conforme atividades florestais

\begin{tabular}{lcl}
\hline Carga de trabalho & Energia (MJ) & Exemplo de atividades \\
\hline Leve & Até 4,18 & Atividades no viveiro \\
Moderado & 4,18 a 6,68 & Operador de máquinas, plantio manual. \\
Pesado & 6,68 a 8,36 & Corte com motosserra ou machado, capina. \\
Extra pesado & Maior 8,36 & Escalar árvores, carregar toras. \\
\hline
\end{tabular}

Fonte: Seixas (1991).

b) Insumos: energia direta via corretivos e fertilizantes

A energia agregada aos fertilizantes é função da demanda de energia exigida na produção, embalagem, transporte e aplicação. Na Tabela 7 são apresentados valores médios para a energia requerida para cada um desses segmentos. A maior demanda para produção de nutrientes em relação ao total recai sobre o nitrogênio $(\mathrm{N})$, cerca de $90 \%$, e de $50 \%$ para $\mathrm{P}_{2} \mathrm{O}_{5}$ e $\mathrm{K}_{2} \mathrm{O}$ (Bruno, 1985). 
Tabela 7. Valores médios mundiais de energia para produção e embalagem de nutrientes primários

\begin{tabular}{lccc}
\hline & \multicolumn{2}{c}{ Demanda de energia por nutriente } & $\left(\mathbf{G J . t}^{-1}\right)$ \\
Segmento & $\mathrm{N}$ & $\mathrm{P}_{2} \mathrm{O}_{5}$ & $\mathrm{~K}_{2} \mathrm{O}$ \\
\hline Produção & 69,4 & 7,7 & 6,4 \\
Embalagem & $\mathbf{8 , 6}$ & 9,8 & 7,3 \\
Total & $\mathbf{7 8 , 1}$ & 17,5 & 13,7 \\
\hline
\end{tabular}

Fonte: Bruno (1985).

Conforme citado por Bruno (1985), a indústria nacional tem promovido melhorias na eficiência de produção. Destacam-se como itens mais importantes o transporte e a eficiência agronômica dos fertilizantes. Os gastos de energia no item transporte do fertilizante normalmente apresentam-se elevados em função do óleo diesel como combustível, podendo ser iguais aos de produção devido à localização das indústrias em todo o País. Assim, a uma maior eficiência energética está associado um menor consumo específico (CE) de insumos energéticos, aqui denominado "consumo específico de energia" definido na equação 3 como:

$$
C E e=\frac{E_{\text {Consumida }}}{P_{\text {utill }}}
$$

$\mathrm{CEe}=$ consumo específico de energia $\left(\mathrm{MJ} . \mathrm{kg}^{-1}, \mathrm{MJ} . \mathrm{I}^{-1}, \mathrm{MJ} . \mathrm{R} \$^{-1}\right)$

$\mathrm{E}_{\text {consumida }}=$ Energia consumida (MJ)

$P_{\text {útil }}=$ Produto útil $(\mathrm{kg}, \mathrm{l}, \mathrm{R} \$)$

Serra et al. (1979) consideraram os fertilizantes na matriz energética brasileira como semelhantes aos da economia norte americana, onde, de modo geral, computaram o gasto energético médio de $307 \mathrm{MJ} . \mathrm{kg}^{-1}$ para o insumo.

Pimentel (1980) considerou que a energia para produzir o ingrediente ativo do herbicida 2,4-D é de $101,6 \mathrm{MJ} \cdot \mathrm{kg}^{-1}$ e do inseticida Diuron 270MJ. $\mathrm{kg}^{-1}$. Quando consideradas as etapas de produção, de formulação, de embalagem e de transporte, o 
consumo específico médio de energia para herbicidas passa a ser de $349 \mathrm{MJ} . \mathrm{kg}^{-1}$ e para inseticidas passa a ser de 312MJ.kg-1 . Segundo Mello (2000) a formulação, a embalagem e o transporte correspondem a $1 / 3$ do total do gasto energético no processo.

\subsubsection{Energia indireta}

A quantia de energia consumida na fabricação de máquinas e implementos consiste na energia usada na extração, transporte e refino de minérios e a energia usada nos processos de fabricação, manutenção e reparos (Doering, 1980 e Fluck, 1985).

Segundo Doering (1980), a contabilidade da energia contida na maquinaria pode apresentar muitas fontes de variação de origem natural e antrópica como eficiência operacional, horas de utilização no ano, variações edafoclimáticas, manejo adotado. $\mathrm{O}$ autor classifica o cálculo de energia agregada na maquinaria em três categorias, sendo:

a) Energia contida no material utilizado na fabricação das peças das máquinas.

b) Energia utilizada na manufatura da máquina e seus componentes.

c) Energia contida e utilizada na fabricação, reparo e manutenção de peças e materiais ao longo da vida útil.

Pela estimativa do autor anteriormente citado, o consumo de energia primária para fabricar e operar um trator tem diversas fontes, como mostra a Tabela 8 a seguir. Nas operações agrícolas a energia agregada na maquinaria é $77 \%$ da energia direta usada na fabricação e montagem. 
Tabela 8. Distribuição média do consumo de energia direta por fonte

\begin{tabular}{lc}
\hline \multicolumn{1}{c}{ Fonte de energia direta } & Participação (\%) \\
\hline Derivados de petróleo & 68 \\
Energia elétrica & 16 \\
Gás natural & 12 \\
GLP & 3 \\
Outras & 1 \\
\hline
\end{tabular}

Fonte: Adaptado de Doering (1980).

Fluck (1985) sugere que a medição pode ser feita multiplicando-se os custos da máquina pelo consumo energético ao longo da vida útil. Essa técnica tem sido utilizada para determinar o custo energético de reparos e manutenções das máquinas agrícolas. $\mathrm{O}$ autor propôs dois modelos descritos como "modelo de custo e reparos na vida útil" e "modelo dos custos de fabricação". O primeiro é baseado no custo acumulado de reparos e manutenções ao longo da vida útil para cada tipo de máquina e o segundo na comparação de dados econômicos da indústria de tratores.

Doering (1980), Pimentel (1980) e Herendreen (1981) consideraram o total da energia agregada na fabricação e reparos para um trator de 97,5kW (130HP) em cerca de 418GJ. De acordo com Mello (2000), se considerado o preço de venda de um trator semelhante no Brasil e transformado esse valor em energia, o valor energético seria de 348GJ. O autor considera esta diferença $20 \%$ inferior possível devido àquelas estimativas terem sido feitas em 1980, quando a relação energia / PIB era menor que na época de seu trabalho.

Segundo BEN (2000), o consumo de energia na produção de ratores é da ordem de $60 \mathrm{GJ} \cdot \mathrm{kg}^{-1}$ enquanto que edificações como prédios e oficinas são respectivamente de $11,34 \mathrm{GJ}$ e $7,14 \mathrm{GJ}$ por metro quadrado. 


\subsection{Sistemas mecanizados de colheita e eficiência energética}

De acordo com Machado (2002), o sistema de colheita florestal pode ser definido como um conjunto de atividades para o fornecimento constante de madeira à fabrica, variando em função do relevo, do padrão e produção da floresta, sortimento e uso final da madeira e das máquinas e equipamentos disponíveis. Os sistemas podem ser classificados quanto à forma da madeira manipulada na fase de extração, do local de processamento e do grau de mecanização. Ainda segundo o autor, há várias máquinas disponíveis no mercado para as diversas operações de colheita, tendo - se como principais módulos totalmente mecanizados o "harvester" e "forwarder" para o sistema de toras curtas e o "feller - buncher", "skidder" e processador para o sistema de toras longas.

Ainda segundo Machado (2002), "harvester" ou colhedora pode executar, simultaneamente, as operações de derrubada, desgalhamento, traçamento, descascamento e empilhamento da madeira. É composta por máquina base de pneus ou esteira, uma lança hidráulica e um cabeçote. $O$ "feller-buncher" ou trator florestal cortador - acumulador consiste de um trator de pneus ou esteira com cabeçote que realiza o corte e o empilhamento de árvores. $\mathrm{O}$ "forwarder" é uma máquina projetada para ser utilizada no sistema de toras curtas, executando a extração da madeira. Possui um chassi articulado com tração tipo $4 \times 4,6 \times 6$ ou $8 \times 8$, e grua hidráulica usada no carregamento e descarregamento. $\mathrm{O}$ "skidder" é uma máquina projetada para trabalhar no sistema de toras longas, executando o arraste de feixes de fustes. É composto por máquina base de pneus ou esteira equipada com garra ou guincho. $\mathrm{O}$ "clambunk skidder" também é uma máquina destinada ao arraste de feixes de fustes, no entanto diferencia-se por ter uma grua de carregamento que coloca toras ou fustes sobre uma garra invertida. $\mathrm{O}$ arraste é feito como nos demais "skidders". O processador florestal é responsável pelo traçamento ou toragem da madeira no comprimento desejado. É composto por máquina base de pneus ou esteiras e um cabeçote com serra de acionamento hidráulico. 
Seixas (1997) comparou os efeitos causados sobre a brotação do eucalipto pelas máquinas utilizadas no sistema mecanizado de colheita. No comparativo entre o módulo mecanizado, composto por "feller - buncher" e "skidder" e o módulo semi mecanizado composto por motosserra e extração com caminhão, o sistema mecanizado causou maior impacto. Em levantamento semelhante comparou o sistema de toras curtas ("harvester" e "forwarder") com o de toras longas ("feller - buncher" e "skidder"), concluindo sobre a vantagem do "harvester" sobre os demais equipamentos.

Segundo Seixas \& Oliveira Junior (2001), no Brasil predominam dois sistemas utilizados na colheita florestal, cujos módulos foram desenvolvidos em função dos tipos de máquinas e manipulação da madeira, o sistema escandinavo "cut - to - lenght" (toras curtas) e o sistema norte americano "tree - lenght" (toras longas), tendo verificado que ambos os módulos de colheita podem provocar distúrbios ao solo dependendo das condições de umidade e do relevo. Os autores alertam para evitar a generalização do conceito de que o módulo "feller - buncher" e "skidder" cause mais danos que o "harvester" e "forwarder" em termos de compactação.

Segundo Cardoso (2004), a Veracel busca a redução de 35\% nos custos de colheita modificando o módulo mecanizado do sistema de "toras curtas" para o de "toras longas", mas somente será implementada se mantiver ou reduzir os níveis de impactos em relação ao atual processo. Os principais impactos considerados são a exportação de nutrientes, o teor de matéria orgânica no solo e a eficiência energética das operações, medido este último pelo consumo de combustíveis e lubrificantes em relação ao volume de madeira produzido $\left(1 . \mathrm{m}^{-3}\right)$.

A interface da colheita mecanizada com novos plantios busca a otimização dos recursos com a diminuição do consumo de energia (diesel, gasolina e óleo lubrificante) e diminuição da emissão de $\mathrm{CO}_{2}$ como forma de adequação aos processos de certificação, tais como; ISO 9001 (qualidade), ISO 14001 (ambiente), OHSAS 18001 (segurança e saúde ocupacional), CERFOR e FSC (manejo florestal) e Normas de Gestão Social (Cardoso, 2004 e Vojciechovski et al., 2004). 
Vojciechovski et al. (2004), citam alguns indicadores utilizados nas empresas Masisa e Terranova, denominando-os de "indicadores ambientais de eco - eficiência" aplicados nas atividades de silvicultura e colheita, como forma de medição e controle do desempenho ambiental para essa adequação, são eles: consumo de energia $(\mathrm{kWh})$, consumo de água $\left(\mathrm{m}^{3}\right)$, rejeitos sólidos $(\mathrm{t})$ e emissão de $\mathrm{CO}_{2}(\mathrm{t})$.

Nota-se a preocupação de avaliar de algum modo a energia dispendida nas operações e relacioná-la como medida do desempenho ambiental nas atividades florestais. No entanto os trabalhos não têm focado para o impacto do dispêndio de energia das operações em cada sistema mecanizado utilizado na colheita de eucalipto.

De acordo com Makkonen (1989) embora o "skidder" apresente menor custo de operação, existem vantagens na utilização do "forwarder" quanto aos distúrbios no solo justamente pela diferença de operação, enquanto o primeiro arrasta a madeira o segundo carrega, minimizando o recalque do solo, conseqüentemente apresentando menor consumo de combustível e a possibilidade de se estender o período de trabalho em condições de solo com maior teor de água, situação na qual o tráfego do "skidder" estaria comprometida.

Soma-se a isso a possibilidade de aumentar a capacidade de carga do "forwarder" com caixas de carga expansíveis, aumentando-se a distância econômica de transporte primário da madeira e aumento da estabilidade da máquina pela redução do centro de gravidade. $\mathrm{O}$ aumento de carga relatado no estudo feito com "forwarder" timberjack 1410D equipado com dispositivo de carga variável "ALS - active load space" foi de $7 \%$ para toras destinadas à serraria e de $23 \%$ para madeira destinada à celulose, além de permitir velocidade média de deslocamento 5 a $10 \%$ maior, dependendo das condições do terreno (Seixas, 2003). 


\section{MATERIAL E MÉTODOS}

Foram montadas planilhas para o cálculo do dispêndio de energia das operações mecanizadas na atividade de colheita em dois sistemas, "toras curtas" e "toras longas", e analisadas conforme a demanda de energia para a sua realização, considerando-se uma floresta de eucalipto padrão do setor de celulose e papel, com atividades mecanizadas e produção de $300 \mathrm{~m}^{3} \cdot \mathrm{ha}^{-1}$ de madeira ao final de sete anos.

Os dados de capacidade operacional, consumo de combustível e insumos representam o desempenho de vinte e sete máquinas, que juntas trabalharam 88.384 horas, colhendo 7.268.729 metros cúbicos de madeira os quais foram coletados em visitas e consultas às empresas Cenibra, Duratex, Ripasa e Votorantim no ano de 2003 e 2004, na região Sudeste compreendendo os Estados de São Paulo e Minas Gerais, na qual encontram-se as áreas de plantio das empresas estudadas.

A primeira etapa trata da caracterização dos procedimentos adotados para a atividade de formação da floresta, considerando-se as atividades de viveiro na formação da muda, de preparo do solo e plantio, de condução da floresta (Anexo A). Para as atividades de silvicultura foram utilizados dados coletados em visita a Ripasa com relação ao parque florestal de Ibiti apresentado no Anexo B. Na segunda etapa o mesmo foi feito sobre a forma representativa das atividades e operações para colher um hectare de eucalipto (Anexos C, D e E).

Os dados médios considerados de cada empresa referem-se aos anos de $2003 \mathrm{e}$ 2004, contabilizando a média geral da produtividade das máquinas que compõem os módulos mecanizados nas regiões e desempenhos nos diversos tipos de relevo, mas com padrão de floresta semelhante $\left(0,18 \mathrm{~m}^{3}\right.$ árvore $\left.^{-1}\right)$. As máquinas foram agrupadas de acordo com a potência, massa e sistema de colheita obtendo-se a média geral do 
desempenho em cada módulo para evitar comparações de capacidade operacional entre as marcas comerciais ou de produtividade entre empresas.

\subsection{Materiais}

A energia direta considerada foi classificada como: a biológica do trabalho humano, a energia do combustível e a energia dos corretivos e agroquímicos. Foi considerada energia indireta a depreciação energética das máquinas, implementos e edificações. Dependendo da atividade algumas entradas foram detalhadas, como foi o caso do viveiro de mudas, onde a depreciação da infra - estrutura foi importante para a análise da energia agregada nas mudas.

Tratores e máquinas foram considerados como produtos manufaturados, que tiveram um consumo de energia para serem construídos, e ao contabilizá-los foram consideradas as horas gastas e a massa do trator utilizado na operação. Assim, pode-se considerá-los como depreciação da energia indireta gasta.

\subsubsection{Descrição do viveiro de mudas}

O detalhamento das operações do viveiro de mudas foi necessário por não haver na bibliografia dados sobre do consumo específico de energia da atividade de produção de mudas. Serra et. al., (1979) não detalharam o processo de produção de mudas, mas enfatizaram a necessidade de se fazê-lo para o setor florestal.

Os cálculos analíticos do consumo energético da produção de mudas foram organizados em planilha conforme exemplo dado no Agrianual (2004) e considerado o viveiro com capacidade média de 20 milhões de mudas anuais no sistema de linha de montagem conforme citado por Zani Filho et al. (1989).

Na produção das mudas foram compilados os dados de Agrianual (2004), Lopes (2004) e de Zani Filho et al. (1989) considerando-se as quantidades de insumos e de estrutura física para se produzir um milheiro de mudas no período médio de 90 dias e vida útil dos componentes de 5 anos, cujos detalhes são descritos a seguir. 
a) Estrutura física: casa de germinação com $2,8 \mathrm{~m}$ de pé direito usando-se tela plástica $30 \%$ de sombra, mesas com telas metálicas a $0,80 \mathrm{~m}$ de altura do solo de $1,60 \mathrm{x}$ $1,10 \mathrm{~m}$, com capacidade para 1240 mudas e lotação de $25 \%$ total de 310 plantas por mesa (Lopes, 2004).

b) Irrigação: feitas automaticamente com auxílio de aspersores de PVC na vazão de 2,0 1.min $\mathrm{mira}^{-1}$ atingir lâmina diária média de $10 \mathrm{~mm}$, pelo bombeamento com motor elétrico fracionário bifásico de $2,2 \mathrm{~kW}(3 \mathrm{CV})$ e massa $24,9 \mathrm{~kg}$. Tempo de funcionamento de $2 \mathrm{~h}$ por dia, 227 dias no ano totalizando consumo de $1 \mathrm{MW}$ de energia elétrica (Zani Filho et al., 1989).

c) Insumos: tubetes de propileno com volume de $55 \mathrm{~cm}^{3}$ em bandejas $60 \times 40 \mathrm{~cm}$ (176 tubetes) na fase de germinação e telas metálicas na fase de desenvolvimento. $\mathrm{O}$ substrato é composto por mistura de casca de pinus, turfa e vermiculita. A adubação de base é feita usando-se fertilizante de liberação lenta Osmocote formulação $10.15 .10 \mathrm{e}$ dose $4 \mathrm{~kg} \cdot \mathrm{m}^{-3}$ (3,3kg.milheiro $\left.{ }^{-1}\right)$. Para adubação de cobertura usou-se fertirrigação na última lâmina de $2 \mathrm{~mm}$ nestas doses e formulações respectivamente: aos 85 dias após a semeadura 3,0g. $\mathrm{l}^{-1}$ de nitrato de cálcio, 1,0g. $\mathrm{l}^{-1}$ de sulfato de amônia, 1,0g. $\mathrm{l}^{-1}$ de nitrato de potássio e $1,2 \mathrm{~g} .1^{-1}$ de sulfato de magnésio. Aos 100 dias após a semeadura foram aplicados 0,69g..$^{-1}$ de $\mathrm{K}_{2} \mathrm{O}$ e 0,42g..$^{-1}$ de cálcio (Lopes, 2004).

Foram consideradas as seguintes concentrações dos nutrientes nestas formulações:

- Cloreto de potássio:

$61 \%$ de $\mathrm{K}_{2} \mathrm{O}$ e

$13 \%$ de $\mathrm{P}_{2} \mathrm{O}_{5}$.

- Nitrato de cálcio:

$14 \%$ de $\mathrm{Ne}$

$19 \%$ de Ca.

- Sulfato de amônio:

$19 \%$ de $\mathrm{Ne}$

$23 \%$ de $\mathrm{S}$.

- Sulfato de magnésio:

$10 \%$ de $\mathrm{Mg}$ e

$14 \%$ de $\mathrm{S}$. 


\subsubsection{Descrição das atividades de Silvicultura}

As atividades silviculturais foram agrupadas em três importantes categorias, sendo: a) preparo do solo, b) transplante e c) manejo e condução da floresta até os 7 anos de idade. $\mathrm{O}$ detalhamento das operações é descrito a seguir.

a) Preparo do solo: A operação é mecanizada com trator de pneus (TP) no preparo e correção do solo, compreendendo também as operações manuais de controle de pragas com utilização de dosador e auxílio de trator com carreta, utilizada para reabastecimento de corretivos.

b) Transplante: considerou-se a operação mecanizada de transplante com utilização do implemento transplantador de linha simples acoplado ao trator de pneus, auxiliado por conjunto trator mais carreta, no reabastecimento das mudas.

c) Manejo: foram consideradas as operações mecanizadas na manutenção de aceiros, na capina química e na adubação de cobertura ao longo dos anos até o corte.

\subsubsection{Descrição da colheita}

O sistema de toras curtas considerado é composto por módulo de "harvester" máquina base Volvo (19,5t de massa e potência de $160 \mathrm{~kW})$ e "forwarder" máquina base Timberjack 1210B (19,5 t e 160kW). No sistema de toras longas o módulo tem como máquinas "feller - buncher" Timberjack 608L (27,2t e 180kW), "clambunk - skidder" Timberjack $1710(19,5 \mathrm{t}$ e $160 \mathrm{~kW})$ e Garra traçadora Timberjack 608B $(27,1 \mathrm{t}$ e $180 \mathrm{~kW})$.

O módulo típico no sistema de toras curtas é composto pelas máquinas ilustradas na Figura 2. O "harvester" corta e processa cada árvore individualmente dentro da área, deixando o resíduo e as toras distribuídos em faixas. $\mathrm{O}$ "forwarder" faz a extração das toras empilhando-as na margem do carreador. 


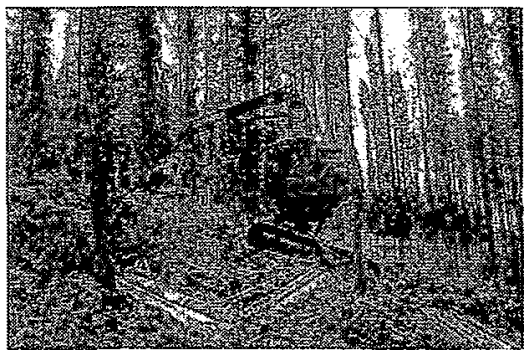

(a) "harvester"

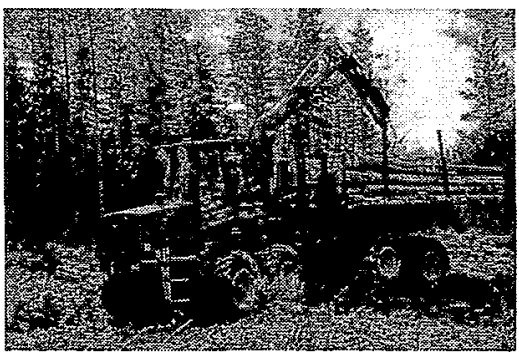

(b) "forwarder"

Figura 2 - Máquinas utilizadas na colheita mecanizada no sistema de toras curtas, (a) "harvester" e (b) "forwarder"

O módulo típico no sistema de toras longas é composto pelas máquinas ilustradas na Figura 3. A seqüência das operações é iniciada pelo "feller - buncher" que corta e acumula, em seu cabeçote de corte, as árvores e em seguida as deposita em feixes ao longo da área. $\mathrm{O}$ arraste desses feixes é feito pelo "clambunk - skidder" até a margem do carreador onde são processadas pela garra traçadora empilhando as toras ao longo dos carreadores.

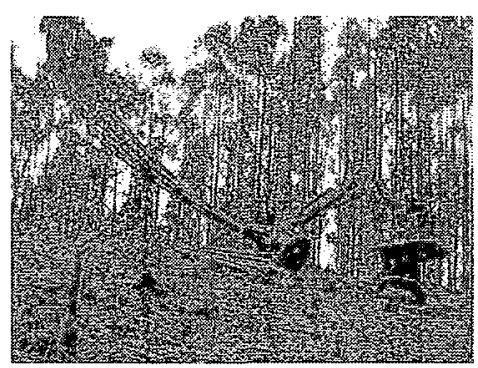

(a) "feller - buncher"

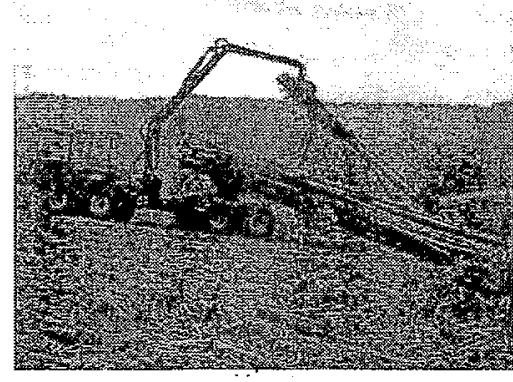

(b) "clambunk"

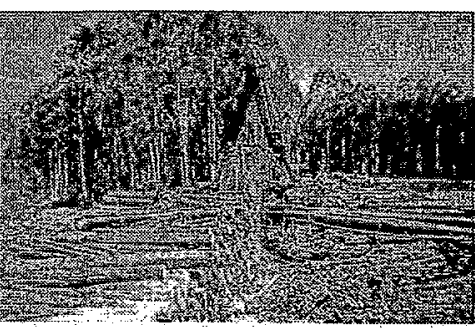

(c) garra traçadora

Figura 3 - Máquinas utilizadas na colheita mecanizada no sistema de toras longas, (a) "feller - buncher", (b) "clambunk" e (c) garra traçadora 


\subsubsection{Descrição do transporte principal}

Nesta atividade foram consideradas as operações de carregamento e descarregamento, respectivamente no campo e na fábrica com carregadores de $27,1 \mathrm{t}$ de massa e $180 \mathrm{~kW}$ de potência. $\mathrm{O}$ transporte rodoviário foi realizado com composição veicular combinada (CVC) denominada bitrem, composto por caminhão trator e dois semi - reboques acoplados, com sete eixos no total $(22,0 \mathrm{t}$ de tara e $300 \mathrm{~kW}$ de potência). $\mathrm{O}$ desempenho e a capacidade foram calculados para uma distância média de $120 \mathrm{~km}$ e peso bruto total combinado - PBTC de $57 \mathrm{t}$. O ponto de carregamento são nas estradas ou carreadores principais e os desempenhos foram estimados a partir dos dados de Seixas \& Oliveira Junior (2004).

\subsection{Métodos}

Nesta análise as entradas de energia foram classificadas e quantificadas, conforme a fonte, considerando-se as características das máquinas, desempenho operacional por operação, com máquinas e com mão de obra, além do consumo de combustível e insumos utilizados em cada atividade do empreendimento florestal conforme esquematizado no organograma da Figura 4. 


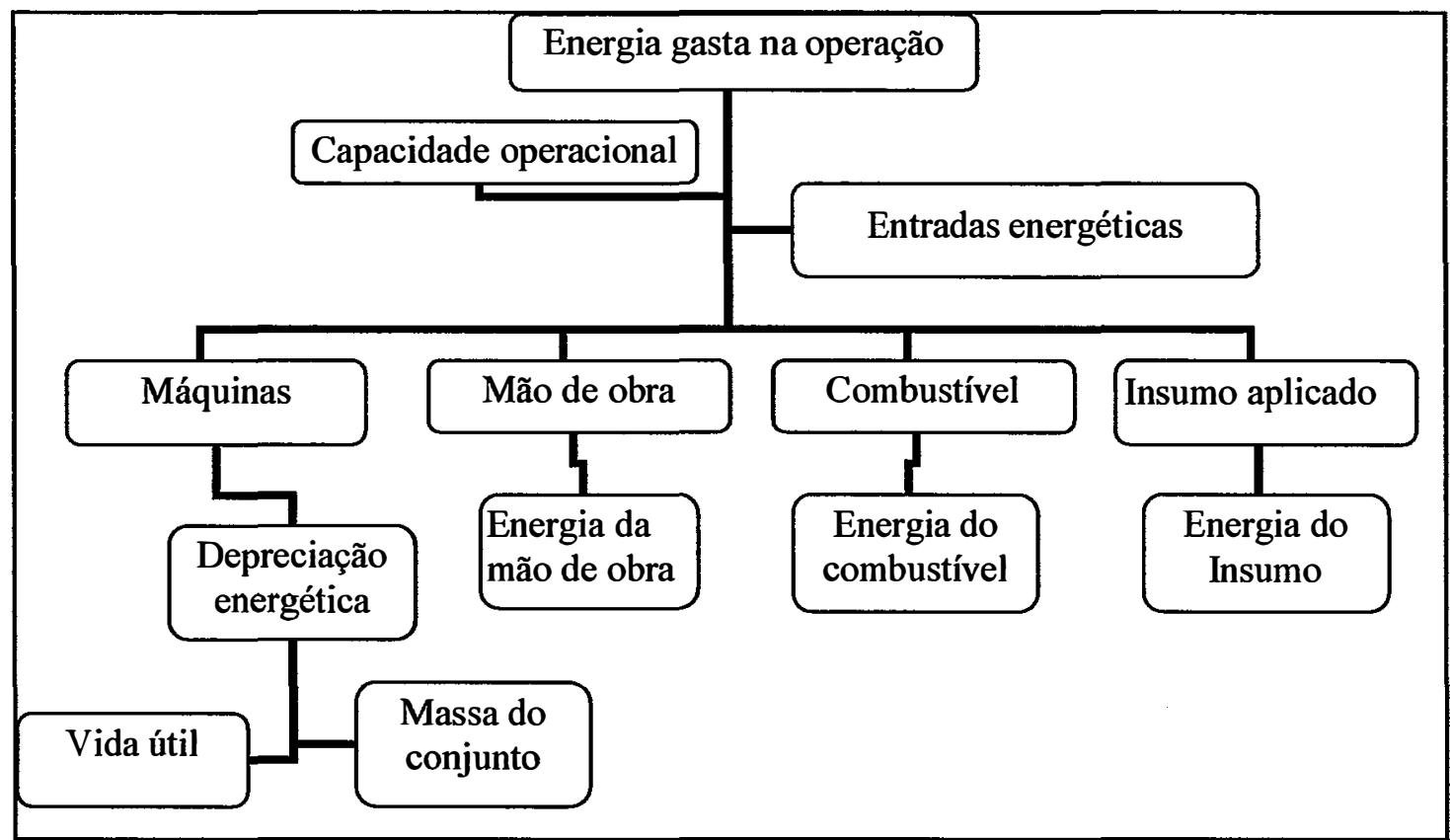

Figura 4 - Organograma do dispêndio energético da operação

Os cálculos de conversão foram classificados conforme o fluxo das entradas de energia externa em energia direta e energia indireta. A atividade de silvicultura do eucalipto foi considerada para calcular a energia total investida na cultura. Para as atividades de implantação e manejo foram consideradas além de operações mecanizadas, também algumas manuais, sendo os dados expressos em unidades de energia por hectare e as operações de colheita e transporte expressos em unidades de energia por metro cúbico de madeira.

\subsubsection{Cálculos para conversão em energia}

As conversões energéticas foram feitas por dois métodos matemáticos (equações e matrizes) conforme a metodologia utilizada por Sartori \& Basta (1999). Buscou-se com isso validar para o setor florestal, a eficácia da metodologia recomendada pelos autores. 


\subsubsection{Método matricial}

Para o cálculo matricial, as entradas de energia foram organizadas no vetor denominado "vetor entradas", que corresponde às intensidades energéticas de cada fluxo de energia. Já o tempo operacional (h.ha $\left.{ }^{-1}\right)$ e consumo de combustível $\left(1 . \mathrm{ha}^{-1}\right)$ e de outros insumos (l.ha ${ }^{-1}$; kg.ha ${ }^{-1}$ ou un.ha $\left.{ }^{-1}\right)$ foram organizados na matriz, denominada "matriz consumo". Multiplicando-se o vetor de entradas energéticas pela matriz consumo tem-se como resultado um vetor com os valores do dispêndio energético em cada atividade, podendo ser expressos em unidades de energia por metro cúbico ou por hectare (J.m ${ }^{-3}$ ou J.ha $^{-1}$ ). O exemplo da Figura 5 mostra como foram organizados os dados do vetor entradas e da matriz consumo.

Vetor entradas $\cdot$ Matriz consumo $=$ Vetor resposta mão de obra máquinas diesel herbicida formicida base cobertura mudas

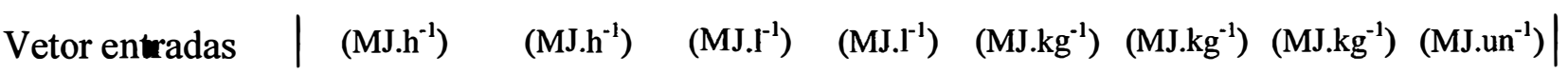
preparo transplante manejo

Mão de obra Máquinas

Diesel

Herbicida

Formicida

Adubo base

Adubo cobertura

Mudas

\begin{tabular}{|c|c|c|}
\hline$\left(h \cdot h^{-1}\right)$ & $\left(\mathrm{h} \cdot \mathrm{ha}^{-1}\right)$ & (h.ha $\left.{ }^{-1}\right)$ \\
\hline$\left(h \cdot h^{-1}\right)$ & $\left(\mathrm{h} \cdot \mathrm{ha}^{-1}\right)$ & $\left(h \cdot h^{-1}\right)$ \\
\hline$\left(1 . h a^{-1}\right)$ & $\left(1 . h a^{-1}\right)$ & $\left(1 . \mathrm{ha}^{-1}\right)$ \\
\hline$\left(1 . h^{-1}\right)$ & $\left(1 . \mathrm{ha}^{-1}\right)$ & $\left(1 . \mathrm{ha}^{-1}\right)$ \\
\hline$\left(\mathrm{kg} \cdot \mathrm{ha}^{-1}\right)$ & $\left(\mathrm{kg} \cdot \mathrm{ha}^{-1}\right)$ & $\left(\right.$ kg.ha $\left.{ }^{-1}\right)$ \\
\hline$\left(\mathrm{kg} \cdot \mathrm{ha}^{-1}\right)$ & $\left(\mathrm{kg} \cdot \mathrm{ha}^{-1}\right)$ & $\left(\right.$ kg.ha $\left.{ }^{-1}\right)$ \\
\hline$\left(\mathrm{kg} \cdot \mathrm{ha}^{-1}\right)$ & $\left(\mathrm{kg} \cdot \mathrm{ha}^{-1}\right)$ & $\left(\mathrm{kg} \cdot \mathrm{ha}^{-1}\right)$ \\
\hline$\left(\right.$ un.ha $a^{-1}$ ) & (un.hat ${ }^{-1}$ ) & \\
\hline
\end{tabular}

Vetor resposta $\left|\left(M^{M} . \mathrm{ha}^{-1}\right) \quad\left(\mathrm{MJ}^{-} \mathrm{ha}^{-1}\right) \quad\left(\mathrm{MJ}^{-} \mathrm{ha}^{-1}\right)\right|$

Total silvicultura $\left|\left(\mathrm{MJ}_{\mathrm{ha}}{ }^{-1}\right)\right|$

Figura 5 - Entrada dos dados organizados no vetor e na matriz 


\subsubsection{Método analítico}

Para o método analítico as equações de cálculo são apresentadas nos tópicos a seguir. Em cada situação utilizaram-se os dados de intensidade energética citados.

\section{Trabalho humano}

O trabalho humano foi considerado na sua forma física em termos de energia gasta em cada tipo de operação, utilizando-se valores médios dos trabalhos feitos por diversos autores (Serra et al., 1978; Serra et al., 1979; Seixas, 1991; Sartori \& Basta, 1999). A intensidade energética média do trabalho humano considerado foi de $2,2 \mathrm{MJ}^{-1}{ }^{-1}$ calculado pela equação 4 da seguinte maneira:

$$
E_{m o}=\frac{I E_{m o}}{C O_{m o}}
$$

$E_{m o}=$ entrada energética com mão-de-obra (MJ.ha $\left.{ }^{-1}\right)$

$\mathrm{IE}_{\mathrm{mo}}=$ intensidade energética do trabalho humano $\left(\mathrm{MJ.h}^{-1}\right)$

$\mathrm{CO}_{\mathrm{mo}}=$ capacidade de campo operacional $\left(\mathrm{ha} \cdot \mathrm{h}^{-1}\right)$ ou $\left(\mathrm{m}^{3} \cdot \mathrm{h}^{-1}\right)$

\section{Máquinas e equipamentos}

Foram caracterizadas as máquinas, os implementos, o número de horas trabalhadas, a potência, o consumo de combustível e de lubrificante. $\mathrm{O}$ cálculo do consumo de energia da operação foi feito através da equação 5 .

$$
E_{m a}=\frac{I E_{m a}}{C O_{m a}}
$$

$\mathrm{E}_{\mathrm{ma}}=$ entrada energética com máquinas $\left(\mathrm{MJ} \cdot \mathrm{ha}^{-1}\right)$ ou $\left(\mathrm{MJ} \cdot \mathrm{m}^{-3}\right)$.

$\mathrm{IE}_{\mathrm{ma}}=$ intensidade energética das máquinas $\left(\mathrm{MJ} \cdot \mathrm{h}^{-1}\right)$.

$\mathrm{CO}_{\mathrm{ma}}=$ capacidade de campo operacional $\left(\mathrm{ha} \cdot \mathrm{h}^{-1}\right)$ ou $\left(\mathrm{m}^{3} \cdot \mathrm{h}^{-1}\right)$. 
As entradas de energia para o cálculo de depreciação energética das máquinas foram assim denominadas; energia contida na matéria prima usada $\left(\mathrm{E}_{\text {contida }}\right)$, energia agregada na fabricação $\left(E_{\text {fabric }}\right)$, energia agregada por reparos e manutenções $\left(E_{R M}\right)$ e coeficiente de ajuste pela vida útil da máquina $\left(\mathrm{E}_{\text {ajuste }}\right)$. Os dados de desempenho operacional, capacidade produtiva, eficiências, bem como consumo de combustível obtidos em cada empresa foram agrupados em médias e feitos os cálculos de depreciação energética conforme proposto por Doering (1980) na equação 6.

$$
I E_{m a}=(E f+E m+E r) \cdot m \cdot 0,333 \cdot R M \cdot V u_{0,82}
$$

$\mathrm{IE}_{\mathrm{ma}}=$ intensidade energética para as máquinas $\left(\mathrm{MJ} \cdot \mathrm{h}^{-1}\right)$.

Ef $=$ valor do consumo energético utilizado para fabricação (MJ.kg $\left.{ }^{-1}\right)$.

Ema $=$ valor energético do material utilizado $\left(\mathrm{MJ}_{\mathrm{kg}} \mathrm{kg}^{-1}\right)$.

$\mathrm{Er} \quad=$ energia gasta com reparos e manutenção $\left(\mathrm{MJ}^{\mathrm{kg}} \mathrm{g}^{-1}\right)$.

$\mathrm{m} \quad=\operatorname{massa}(\mathrm{kg})$.

$\mathrm{Vu}_{0,82}=82 \%$ de vida útil (h)

RM = coeficiente de correção para reparos e manutenções

\section{Insumos}

Fertilizantes e corretivos: as entradas energéticas foram calculadas pela equação 7 e separados de acordo com sua fonte, tendo-se os nitrogenados, fosfatados e potássicos. Foram utilizadas as estimativas energéticas para os fertilizantes de acordo com a metodologia de Engelstad (1985). Para o calcário foi utilizado dado de Serra et al. (1979) e o método desenvolvido por Macedônio \& Picchioni (1985). Os valores adotados são resumidos a seguir: 
1. Nitrogênio (N) 105,0MJ.kg-1

2. Fósforo $\left(\mathrm{P}_{2} \mathrm{O}_{5}\right) \quad 13,0 \mathrm{MJ} \cdot \mathrm{kg}^{-1}$

3. Potássio $\left(\mathrm{K}_{2} \mathrm{O}\right) \quad 6,7 \mathrm{MJ}^{-k^{-1}}$

4. Calcário $\quad 1,7 \mathrm{MJ} \cdot \mathrm{kg}^{-1}$

$$
E_{f e r t}=I E_{f e r t} \cdot D_{i}
$$

$E_{\text {fert }}=$ entrada energética para os fertilizantes (MJ.ha $\left.{ }^{-1}\right)$.

$\mathrm{IE}_{\text {fert }}=$ Intensidade energética dos fertilizantes $\left(\mathrm{MJ}_{\mathrm{kg}}{ }^{-1}\right)$

D = Dose ou Quantidade aplicada (kg.ha $\left.{ }^{-1}\right)$

$\mathrm{i}=$ tipo de fertilizante ou corretivo

Defensivos: foi considerado o produto aplicado em cada etapa da produção, utilizando-se metodologia adotada por Serra et al. (1979) e Pimentel (1980). O cálculo dessa entrada foi feito pela equação 8.

1. herbicida $420,0 \mathrm{MJ} \cdot \mathrm{kg}^{-1}$

2. inseticida $365,0 \mathrm{MJ} \cdot \mathrm{kg}^{-1}$

3. formicida $194,0 \mathrm{MJ} \cdot \mathrm{kg}^{-1}$

4. fungicida $308,0 \mathrm{MJ} \cdot \mathrm{kg}^{-1}$

$$
E_{d e f}=I E_{d e f} \cdot D_{i}
$$

$E_{\text {def }}=$ Entrada energética para os defensivos (MJ.ha $\left.{ }^{-1}\right)$.

$\mathrm{IE}_{\text {def }}=$ Intensidade energética dos defensivos $\left(\mathrm{MJ}_{\mathrm{kg}}{ }^{-1}\right)$.

$\mathrm{D}=$ Dose (ingrediente ativo) do produto utilizado $\left(\mathrm{kg} \cdot \mathrm{ha}^{-1}\right)$.

$\mathrm{i}=$ tipo de defensivo 
Combustivel: a entrada de energia devido ao consumo de combustível foi calculada pela equação 9 , conforme o tipo e desempenho da máquina em cada operação.

$$
E_{\text {comb }}=I E_{\text {comb }} \cdot C \cdot C O
$$

$\mathrm{E}_{\text {comb }}=$ Entrada energética do combustível (MJ.ha ${ }^{-1}$ ).

$\mathrm{IE}_{\text {comb }}=$ Intensidade energética do combustível utilizado $\left(\mathrm{MJ}^{-1} \mathrm{I}^{-1}\right)$.

$\mathrm{C}=$ combustível consumido $\left(1 . \mathrm{m}^{-3}\right)$.

$\mathrm{CO}=$ Capacidade operacional $\left(\right.$ ha. $\left.\mathrm{h}^{-1}\right)$ ou $\left(\mathrm{m}^{3} \cdot \mathrm{h}^{-1}\right)$.

Mudas: Foram feitas avaliações do viveiro calculando-se o valor agregado de energia nas mudas de acordo com a quantidade de insumos usados para se produzir um milheiro. A energia agregada pelas mudas na atividade de transplante foi calculada pela equação 10.

$$
E_{m u}=I E_{m u} \cdot d
$$

$E_{m u}=$ Entrada energética das mudas (MJ.ha $\left.{ }^{-1}\right)$

$\mathrm{IE}_{\mathrm{mu}}=$ Intensidade energética das mudas (MJ.muda ${ }^{-1}$ ).

$\mathrm{d}=$ densidade do plantio (mudas.ha ${ }^{-1}$ ) 


\section{RESULTADOS}

A análise descritiva do consumo de energia nas operações em cada atividade é apresentada a seguir. Inicia-se pela atividade de mudas no viveiro, depois a atividade de silvicultura, a colheita mecanizada, enfatizando-se os sistemas tora curta e tora longa, e, finalmente, a atividade de transporte rodoviário. Os resultados referem-se ao dispêndio energético nas atividades para se produzir, conduzir, colher e transportar um hectare de eucalipto.

\subsection{Cálculo analítico da atividade do viveiro}

A energia agregada nas mudas devido à atividade do viveiro na produção de mudas e os dados de consumo energético das operações e insumos são apresentados na Tabela 9.

Para a produção de um milheiro de mudas de eucalipto nesta simulação foram necessários $772 \mathrm{MJ}$, ou seja, $0,772 \mathrm{MJ}$ por muda. Os insumos tiveram a participação de $94,2 \%$ do dispêndio energético, mão de obra e máquinas os 5,8\% restantes. O principal componente de insumos foi o adubo nitrogenado (36,4\%), mas a energia indireta agregada nas mesas de aço (Tabela 9) também teve grande participação (26,2\%). 
Tabela 9. Investimento energético na atividade de produção de mudas no viveiro

\begin{tabular}{|c|c|c|c|c|c|c|c|c|}
\hline \multicolumn{2}{|l|}{ Fluxos } & \multicolumn{4}{|c|}{ Consumo de insumos por milheiro } & \multicolumn{3}{|c|}{ Energia } \\
\hline Insumos & (un.mir ${ }^{-1}$ ) & preparo & semeadura & manutenção & expedição & & $\left(\right.$ MJ.mil $\left.{ }^{-1}\right)$ & $(\%)$ \\
\hline Sementes & $\mathrm{kg}$ & 0,01 & & & & & 0,024 & 0,0 \\
\hline Osmocote & $\mathrm{kg}$ & 2,2 & & & & & 37,0 & 4,8 \\
\hline Micronutrientes & $\mathrm{kg}$ & 0,3 & & & & & 14,2 & 1,8 \\
\hline Nitrogenados & kg & 3,3 & 0,33 & & & & 280,8 & 36,4 \\
\hline Fosfatados & $\mathrm{kg}$ & 0,2 & 0,22 & 0,15 & 0,25 & & 2,8 & 0,4 \\
\hline Potássicos & $\mathrm{kg}$ & 3,3 & 0,22 & 0,15 & 0,04 & 0,26 & 36,5 & 4,7 \\
\hline Cálcio & $\mathrm{kg}$ & 1,0 & 1,0 & 1,7 & 0,02 & 0,06 & 8,9 & 1,2 \\
\hline Herbicida & 1 & 0,003 & & 0,01 & & & 5,5 & 0,7 \\
\hline Inseticida & $\mathrm{kg}$ & 0,03 & & 0,03 & & & 21,9 & 2,8 \\
\hline Formicida & $\mathrm{kg}$ & & & 0,001 & & & 0,2 & 0,0 \\
\hline Fungicidas & $\mathrm{kg}$ & & & 0,02 & 0,02 & & 12,3 & 1,6 \\
\hline Diesel & 1 & 0,3 & & & & & 11,4 & 1,5 \\
\hline Mesas de aço & $\mathrm{kg}$ & 3,2 & & & & & 202,4 & 26,2 \\
\hline Vermiculita & $\mathrm{kg}$ & 14 & & & & & 0,6 & 0,1 \\
\hline Sombrite & $\mathrm{kg}$ & 1,43 & & & & & 13,6 & 1,8 \\
\hline Plástico & $\mathrm{kg}$ & 7,14 & & & & & 67,9 & 8,8 \\
\hline Tubetes & $\mathrm{kg}$ & 0,79 & & & & & 7,5 & 1,0 \\
\hline Bandeja & $\mathrm{kg}$ & 0,32 & & & & & 3,1 & 0,4 \\
\hline Eletricidade & $\mathrm{kWh}$ & 0,05 & & & & & 0,6 & 0,1 \\
\hline Substrato & $\mathrm{kg}$ & 20,0 & 1,0 & & & & 0,5 & 0,1 \\
\hline Subtotal & & & & & & & 727,4 & 94,2 \\
\hline \multicolumn{9}{|l|}{ Mão de obra } \\
\hline Simples & $\mathrm{h}$ & 0,16 & 0,24 & 0,24 & 0,5 & & 2,5 & 0,3 \\
\hline Qualificada & h & 0,01 & 0,01 & 0,01 & 0,01 & & 0,1 & 0,0 \\
\hline Subtotal & & & & & & & 2,6 & 0,3 \\
\hline \multicolumn{9}{|l|}{ Máquinas } \\
\hline Trator + carreta & $\mathbf{h}$ & 0,01 & 0,01 & 0,01 & 0,01 & & 0,2 & 0,0 \\
\hline Caminhão & h & 0,06 & & & 0,1 & & 4,1 & 0,5 \\
\hline Bomba/irrigação & h & 1,67 & 1,67 & 1,67 & 1,0 & & 37,7 & 4,9 \\
\hline Subtotal & & & & & & & 42,0 & 5,4 \\
\hline TOTAL & MJ & & & & & & 772,0 & 100 \\
\hline
\end{tabular}

un.mil ${ }^{-1}=$ unidades por milheiro de mudas $\quad \mathrm{MJ}_{\mathrm{mil}}{ }^{-1}=$ mega joule por milheiro 


\subsection{Cálculo analítico das atividades de Silvicultura}

Os dados utilizados para os cálculos analítico e matricial de dispêndio energético das operações em cada atividade são apresentados na Tabela 10 a seguir, conforme a característica de cada operação, desempenho e consumo de insumos.

Tabela 10. Descrição, consumo e desempenho das operações na atividade silvicultural

\begin{tabular}{|c|c|c|c|c|c|c|c|c|}
\hline Atividade & Operaçōes & Máquinas & $\begin{array}{l}\text { TOmo } \\
(\text { (h.h.hat })\end{array}$ & $\begin{array}{l}\text { TOmaq } \\
\left(\text { h.hat }^{-1}\right)\end{array}$ & $\begin{array}{l}\text { Diesel } \\
\left(1 . \mathrm{ha}^{-1}\right)\end{array}$ & produto & $\begin{array}{l}\text { insumos } \\
\left(\text { un.hat }^{-1}\right)\end{array}$ & (un) \\
\hline & controle de formigas & TP $58 \mathrm{~kW}+$ carreta & 0,5 & 0,5 & 4,0 & & & \\
\hline & & dosador & 8,0 & & & formicida & 4 & $\mathrm{~kg}$ \\
\hline & subsolagem & TP $120 \mathrm{~kW}+$ escarificador & 1,20 & 1,2 & 16,8 & & & \\
\hline \multirow[t]{5}{*}{ Preparo solo } & adubação & & & & & 06:30:06 & 340 & $\mathrm{~kg}$ \\
\hline & aplicação herbicida & & & & & herbicida & 2 & 1 \\
\hline & subtotal & & 9,7 & 1,7 & 20,8 & & & \\
\hline & transplantio mecaniz & TP $100 \mathrm{~kW}+$ mansplantadora & 8,0 & 8,0 & 96,0 & & & \\
\hline & & TP $58 \mathrm{~kW}+$ carreta & 0,5 & 0,5 & 4,0 & mudas & 1667 & un \\
\hline \multirow[t]{7}{*}{ Transplante } & combate formiga & dosador & 8,0 & & & formicida & 4 & $\mathrm{~kg}$ \\
\hline & & $\mathrm{TP} 58 \mathrm{~kW}+$ carreta & 0,5 & 0,5 & 4,0 & & & \\
\hline & irrigação & TP 58kW + carreta & 0,2 & 0,2 & 1,6 & água & 1667 & 1 \\
\hline & transplantio 30dias & chucho & 8,0 & & & mudas & 333 & un \\
\hline & & TP $58 \mathrm{~kW}+$ carreta & 0,5 & 0,5 & 4,0 & & & \\
\hline & subtotal & & 25,7 & 9,7 & 109,6 & total mudas & 2000 & un \\
\hline & aceiros & TP $120 \mathrm{~kW}$ & 0,5 & 0,5 & 7,0 & & & \\
\hline \multirow[t]{5}{*}{ Manejo } & capina quimica & TP $100 \mathrm{~kW}$ & 1,2 & 1,2 & 14,4 & herbicida & 2 & 1 \\
\hline & adubação cobertura & $\mathrm{TP} 100 \mathrm{~kW}$ & 1,2 & 1,2 & 14,4 & $10: 00: 10$ & 240 & $\mathrm{~kg}$ \\
\hline & combate formiga & dosador & 8,0 & & & formicida & 2 & $\mathrm{~kg}$ \\
\hline & subtotal & & 10,9 & 2,9 & 35,8 & & & \\
\hline & Total & & 46,3 & 14,3 & 166,2 & & & \\
\hline
\end{tabular}

Fonte: Ripasa S/A (2003).

TOmo $=$ Tempo operacional com mão de obra

Produtividade $=50 \mathrm{~m}^{3} \cdot \mathrm{ha}^{-1} \cdot$ ano $^{-1}$

TOmaq $=$ Tempo operacional com máquinas

$\mathrm{TP}=$ trator de pneus 
Na Tabela 11 são apresentados os dispêndios energéticos para as operações dentro da atividade de silvicultura adotando-se plantio mecanizado. As entradas de energia foram classificadas em energia da mão de obra (Emo), das máquinas (Ema), do combustível (Ecomb) e dos insumos (Einsumo) de acordo com os consumos de cada item por hectare.

Tabela 11. Investimento energético das atividades de silvicultura mecanizada

\begin{tabular}{|c|c|c|c|c|c|c|}
\hline Atividades & $\begin{array}{c}\mathbf{E}_{\mathrm{mo}} \\
\left(\mathrm{MJ.ha}^{-1}\right)\end{array}$ & $\begin{array}{c}\mathbf{E}_{\mathrm{ma}} \\
\left({\left.\mathrm{MJ} . h a^{-1}\right)}^{-1}\right.\end{array}$ & $\begin{array}{c}\mathbf{E}_{\text {comb }} \\
\left(\mathbf{M J} \mathbf{h a}^{-1}\right)\end{array}$ & $\begin{array}{c}\mathbf{E}_{\text {insumo }} \\
\left({\left.\mathbf{M J} . h a^{-1}\right)}^{-1}\right)\end{array}$ & $\begin{array}{c}\text { TOTAL } \\
\left(\text { MJ.ha }^{-1}\right)\end{array}$ & $(\%)$ \\
\hline Preparo do solo & 21,3 & 20,9 & 791,0 & 5180,9 & 6014,1 & 33,4 \\
\hline Transplante & 56,5 & 118,8 & 4154,4 & 2321,7 & 6651,4 & 37,0 \\
\hline Manejo e cultivo & 24,0 & 35,6 & 1361,4 & 3909,2 & 5330,2 & 29,6 \\
\hline Total & 101,9 & 175,3 & 6306,8 & 11411,7 & 17995,6 & 100 \\
\hline \multicolumn{7}{|c|}{$\mathrm{E}_{\mathrm{mo}}=$ entradas energéticas pela mão de obra } \\
\hline \multicolumn{7}{|c|}{$\mathrm{E}_{\mathrm{ma}}=$ entradas energéticas pelas máquinas } \\
\hline \multicolumn{7}{|c|}{$\mathrm{E}_{\mathrm{comb}}=$ entradas energéticas pelo uso de diesel } \\
\hline
\end{tabular}

O resultado final de $17.995,6 \mathrm{MJ} \cdot \mathrm{ha}^{-1}$ representou um investimento médio de 2570,8MJ.ha ${ }^{-1} \cdot$ ano $^{-1}$ na fase silvicultural. O maior investimento energético foi na atividade de transplante, devido a baixa produtividade do conjunto trator mais transplantatora e a de menor investimento foi a atividade de manejo e cultivo.

Se consideradas as formas de energia média investida na atividade de silvicultura, verificou-se que a mão de obra representou a menor participação no dispêndio de energia, $0,6 \%$ do total, a depreciação energética das máquinas $1,0 \%$, 0 combustível cerca de $35,0 \%$ e os insumos (fertilizantes, herbicidas e formicidas), a grande parte, com $63,4 \%$. Considerando-se o valor das mudas como item insumo, estas representaram $60,6 \%$ do consumo energético na atividade de transplante. 


\subsection{Cálculo matricial das atividades de silvicultura}

A Figura 6 mostra o resultado do cálculo pelo método matricial na atividade de silvicultura conforme as formas de energia.

\begin{tabular}{|c|c|c|c|c|c|c|c|c|}
\hline \multirow{3}{*}{ Vetor entrada } & mão de obra & máquinas & diesel & herbicida & formicida & base & cobertura & \multirow[t]{2}{*}{ mudas } \\
\hline & & & & & & & & \\
\hline & 2,2 & 12,2 & 38 & 420 & 194 & 10,6 & 11,17 & 0,77 \\
\hline \multicolumn{9}{|l|}{ Matriz consumo } \\
\hline Mão de obra & 9,7 & 25,7 & 10,9 & & & & & \\
\hline Máquinas & 1,7 & 9,7 & 2,9 & & & & & \\
\hline Diesel & 20,8 & 109,6 & 35,8 & & & & & \\
\hline Herbicida & 2,0 & 0 & 2,0 & & & & & \\
\hline Formicida & 4,0 & 4,0 & 2,0 & & & & & \\
\hline Adubo base & 340 & 0 & 0 & & & & & \\
\hline Adubo cobertura & 0 & 0 & 240 & & & & & \\
\hline Mudas & 0 & 2000 & 0 & & & & & \\
\hline & preparo & transplante & manejo & & & & & \\
\hline $\begin{array}{l}\text { Vetor resposta } \\
\qquad\left(\mathrm{MJ} \mathrm{ha}^{-1}\right)\end{array}$ & 6053 & 6660 & 5329 & & & & & \\
\hline $\begin{array}{c}\text { Total silvicultura } \\
\left(\mathrm{MJ}^{-h^{-1}}\right)^{-}\end{array}$ & 18042 & & & & & & & \\
\hline
\end{tabular}

Figura 6 - Cálculo matricial para as atividades de silvicultura

Pelo método do cálculo matricial o total de energia investido na atividade silvicultura foi de 18.042MJ.ha ${ }^{-1}$, cerca de 2.577MJ.ha ${ }^{-1}$.ano ${ }^{-1}$. Considerando-se uma produção final de $300 \mathrm{~m}^{3} \cdot \mathrm{ha}^{-1}$ de madeira, o dispêndio de energia equivale a $60,14 \mathrm{MJ} . \mathrm{m}^{-3}$. 


\subsection{Cálculo analítico da atividade de colheita}

Os resultados da capacidade operacional das máquinas são apresentados na Tabela 12 considerando-se esses valores para os dois métodos de cálculo. Os valores representam a média de produtividade das máquinas a partir dos dados coletados nas empresas, levando-se em consideração o mesmo padrão da floresta e volume médio por árvore de $0,18 \mathrm{~m}^{3}$ considerando-se as diferentes marcas e modelos de máquinas pesquisadas.

Tabela 12. Capacidade operacional e consumo das máquinas em cada sistema de colheita

\begin{tabular}{cllcc}
\hline Sistema & \multicolumn{1}{c}{ Operação } & \multicolumn{1}{c}{ Máquina } & $\mathbf{C O}\left(\mathbf{m}^{\mathbf{3}} \cdot \mathbf{h}^{-1}\right)$ & Diesel $\left(\mathbf{l} \cdot \mathbf{h}^{-1}\right)$ \\
\hline Toras curtas & Corte e processo & "Harvester" & 35,36 & 17,85 \\
& Extração & "Forwarder" & 42,76 & 17,10 \\
\multirow{2}{*}{ Toras longas } & Corte & "Feller - buncher" & 86,22 & 32,78 \\
& Extração & "Clambunk - skidder" & 78,44 & 24,42 \\
& Processo & Garra traçadora & 44,00 & 14,52 \\
\hline
\end{tabular}

$\mathrm{CO}=$ Capacidade Operacional

As máquinas utilizadas em cada sistema de colheita foram depreciadas em termos de energia agregada, contabilizando-se a matéria prima usada, a energia consumida na fabricação, com reparos e manutenções ao longo da vida útil. Foram considerados nos cálculos a massa e potência das máquinas e seu uso anual, conforme metodologia proposta por Doering (1980) e descrita pela equação 5. O resultado desses cálculos é apresentado na Tabela 13 a seguir, tendo-se a energia agregada por hora de utilização dessas máquinas.

Os resultados mostram que as máquinas de maior potência apresentaram maior valor de energia agregada por hora, principalmente em função da maior massa. Essa 
diferença nos dados de depreciação energética foi considerada nas entradas de energia utilizadas em ambos os tipos de cálculos.

Tabela 13. Depreciação energética das máquinas utilizadas na colheita mecanizada

\begin{tabular}{|c|c|c|c|c|c|c|c|c|c|}
\hline Máquina & $\begin{array}{c}\text { Massa } \\
\text { (t) } \\
\end{array}$ & $\begin{array}{c}\text { Potência } \\
(\mathrm{kW})\end{array}$ & $\begin{array}{l}\text { V.útil } \\
\text { (anos) } \\
\end{array}$ & $\begin{array}{c}\text { Uso } \\
\left(\text { h.ano }^{-1}\right) \\
\end{array}$ & $\begin{array}{r}\mathrm{E}_{\text {contida }} \\
\left(\mathrm{MJ} \cdot \mathrm{h}^{-1}\right) \\
\end{array}$ & $\begin{array}{c}\mathrm{E}_{\text {fabric }} \\
\left(\mathrm{MJ} \cdot \mathrm{h}^{-1}\right) \\
\end{array}$ & $\begin{array}{c}\mathrm{E}_{\mathrm{RM}} \\
\left(\mathrm{MJ} \cdot \mathrm{h}^{-1}\right) \\
\end{array}$ & $\begin{array}{c}\text { ajuste } \\
\left(\mathrm{MJ} \cdot \mathrm{h}^{-1}\right) \\
\end{array}$ & 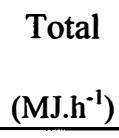 \\
\hline "Harvester" & 19,5 & 160 & 5 & 6000 & 32,7 & 9,5 & 10,4 & 34,6 & 45,0 \\
\hline "Forwarder" & 19,5 & 160 & 5 & 6000 & 32,7 & 9,5 & 10,4 & 34,6 & 45,0 \\
\hline "Feller" & 27,2 & 180 & 5 & 6000 & 45,5 & 13,2 & 14,5 & 48,2 & 62,7 \\
\hline "Clambunk" & 19,5 & 160 & 5 & 6000 & 32,7 & 9,5 & 10,4 & 34,6 & 45,0 \\
\hline Garra & 27,1 & 180 & 5 & 6000 & 44,8 & 13,2 & 14,3 & 47,6 & 61,9 \\
\hline Carregador & 27,1 & 180 & 5 & 4000 & 33,6 & 8,0 & 10,3 & 34,1 & 46,4 \\
\hline Caminhão & 22,0 & 300 & 8 & 4000 & 34,0 & 8,2 & 6,5 & 34,6 & 41,1 \\
\hline
\end{tabular}

\subsubsection{Sistema de toras curtas}

O consumo energético no sistema de colheita mecanizada de toras curtas é apresentado na Tabela 14. Foram consideradas as capacidades de operação das máquinas conforme o módulo de operações caracterizado no item 3.1.2.

Tabela 14. Investimento energético na atividade de colheita no sistema de toras curtas

\begin{tabular}{llcccc}
\hline Operação & Máquina & $\begin{array}{c}\text { Emo } \\
\left(\mathbf{M J} . m^{-3}\right)\end{array}$ & $\begin{array}{c}\text { Ema } \\
\left(\mathbf{M J . m}^{-3}\right)\end{array}$ & $\begin{array}{c}\text { Ecomb } \\
\left(\mathbf{M J . m}{ }^{-3}\right)\end{array}$ & $\begin{array}{c}\text { Total } \\
\left(\mathbf{M J . m}^{-3}\right)\end{array}$ \\
\hline Corte e processo & "Harvester" & $\mathbf{0 , 0 6}$ & 1,27 & 19,13 & 20,47 \\
Extração & "Forwarder" & $\mathbf{0 , 0 5}$ & 1,05 & 15,16 & 16,26 \\
\multicolumn{1}{c}{ Total } & & $\mathbf{0 , 1 1}$ & $\mathbf{2 , 3 3}$ & $\mathbf{3 4 , 2 9}$ & $\mathbf{3 6 , 7 3}$
\end{tabular}

Emo $=$ entradas energéticas pela mão de obra $\quad$ Ema $=$ entradas energéticas pelas máquinas Ecomb $=$ entradas energéticas pelo uso de diesel 
Nesta atividade foi necessário o investimento energético de 36,73MJ para se colher um metro cúbico de madeira. Desse total a energia agregada pela mão de obra (Emo) representou apenas 0,3\%, enquanto que pelas máquinas (Ema) $6,3 \%$ e pelo combustível (Ecomb) $93,4 \%$. Se considerada a produção de $300 \mathrm{~m}^{3} \cdot \mathrm{ha}^{-1}$, isto representou um consumo energético de 11.020MJ.ha ${ }^{-1}$.

\subsubsection{Sistema de toras longas}

Na Tabela 15 é apresentado o resultado do consumo energético no sistema de colheita mecanizada toras longas.

Tabela 15. Investimento energético na atividade de colheita no sistema de toras longas

\begin{tabular}{lccccc}
\hline Operação & Máquina & $\begin{array}{c}\text { Emo } \\
\left.(\mathbf{M J . m})^{-3}\right)\end{array}$ & $\begin{array}{c}\text { Ema } \\
\left(\mathbf{M J . m}^{-3}\right)\end{array}$ & $\begin{array}{c}\text { Ecomb } \\
\left.(\mathbf{M J . m})^{-3}\right)\end{array}$ & $\begin{array}{c}\text { Total } \\
\left(\mathbf{M J . m}^{-3}\right)\end{array}$ \\
\hline Corte & "Feller - buncher" & $\mathbf{0 , 0 3}$ & $\mathbf{0 , 7 3}$ & 14,41 & 15,16 \\
Extração & "Clambunk - skidder" & $\mathbf{0 , 0 3}$ & 0,57 & 11,80 & 12,40 \\
Processo & Garra traçadora & $\mathbf{0 , 0 5}$ & 1,41 & 12,51 & 13,97 \\
Total & & $\mathbf{0 , 1 0}$ & $\mathbf{2 , 7 1}$ & $\mathbf{3 8 , 7 2}$ & $\mathbf{4 1 , 5 3}$
\end{tabular}

$E m o=\overline{\text { entradas energéticas pela mão de obra } \quad \text { Ema }=\text { entradas energéticas pelas máquinas }}$ Ecomb $=$ entradas energéticas pelo uso de diesel

O investimento energético no sistema tora longa foi de $41,53 \mathrm{MJ}^{-3} \mathrm{~m}^{-3}$. A distribuição relativa da energia agregada de acordo com o fluxo externo, teve a participação de $0,2 \%, 6,5 \%$ e $93,2 \%$ para mão de obra, máquinas e combustível respectivamente. Considerando-se a produção de $300 \mathrm{~m}^{3} \cdot \mathrm{ha}^{-1}$, isto representou um dispêndio energético total de $12.460 \mathrm{MJ} \cdot \mathrm{ha}^{-1}$.

\subsection{Cálculo analítico da atividade de transporte}

Os dados para os cálculos desta atividade são apresentados na Tabela 16. 
Tabela 16. Desempenho das operações de transporte rodoviário e de cargas

\begin{tabular}{lccc}
\hline Operação & Máquina & $\mathbf{C O}\left(\mathrm{m}^{3} \cdot \mathbf{h}^{-1}\right)$ & Diesel $\left(\mathbf{l} \cdot \mathbf{h}^{-1}\right)$ \\
\hline Carga / descarga & Garra estacionária & 57,2 & 18,50 \\
Transporte principal & Veículo Bitrem 255kW & 6,9 & 6,48 \\
\hline
\end{tabular}

Fonte: Seixas \& Oliveira Junior (2004).

$\mathrm{CO}=$ Capacidade Operacional

O investimento energético na atividade de transporte modal rodoviário considerando-se a composição veicular combinada - CVC, denominado Bitrem é apresentado na Tabela 17.

Tabela 17. Investimento energético na carga e no transporte rodoviário

\begin{tabular}{|c|c|c|c|c|c|}
\hline Operação & Máquina & $\begin{array}{c}\mathbf{E}_{\mathrm{mo}} \\
\left(\mathbf{M J} \cdot \mathrm{m}^{-3}\right)\end{array}$ & $\begin{array}{c}\mathbf{E}_{\mathrm{ma}} \\
\left(\mathbf{M J} . \mathrm{m}^{-3}\right)\end{array}$ & $\begin{array}{c}\mathbf{E}_{\text {comb }} \\
\left(\mathbf{M J J} \cdot \mathbf{m}^{-3}\right)\end{array}$ & $\begin{array}{c}\text { Total } \\
\left(\text { MJ.m }{ }^{-3}\right)\end{array}$ \\
\hline Carga / descarga & Carregador & 0,04 & 0,81 & 12,26 & 13,11 \\
\hline Deslocamento & Veículo Bitrem & 0,32 & 5,95 & 35,65 & 41,92 \\
\hline TOTAL & & $\mathbf{0 , 3 6}$ & 6,77 & 47,91 & 55,03 \\
\hline
\end{tabular}

A atividade de transporte apresentou o valor de 55,03MJ.m ${ }^{-3}$, sendo $76,2 \%$ devido ao deslocamento até a fábrica e $23,8 \%$ devido ao carregamento e descarregamento. A distribuição da energia agregada conforme o fluxo foi de $0,6 \%$ pela mão de obra $\left(\mathrm{E}_{\mathrm{mo}}\right), 12,3 \%$ pelas máquinas $\left(\mathrm{E}_{\mathrm{ma}}\right)$ e $87,1 \%$ pelo combustível $\left(\mathrm{E}_{\text {comb }}\right)$. Representou $16.509 \mathrm{MJ} \cdot \mathrm{ha}^{-1}$ se considerada a mesma produção da floresta citada na atividade de colheita.

Dessa forma o total de energia consumida somando-se a atividade de colheita e transporte pelo método de equações foi de $91,76 \mathrm{MJ} \cdot \mathrm{m}^{-3}$ para o sistema de toras curtas e de $96,56 \mathrm{MJ} . \mathrm{m}^{-3}$, para o sistema de toras longas. 


\subsection{Cálculo matricial das atividades de colheita e transporte}

As entradas da matriz e do vetor consumo são mostradas na Figura 7. $\mathrm{O}$ vetor resposta indica o dispêndio energético por tipo de máquina usada e para se obter o valor final de cada módulo é feito a soma desses valores conforme a máquina utilizada na operação. O mesmo é apresentado para a atividade de ransporte considerando-se as operações de carregamento e descarregamento como sendo uma única de carga. Os valores expressam o dispêndio de energia para se manipular um metro cúbico de madeira.

\begin{tabular}{|c|c|c|c|c|c|c|c|c|c|}
\hline \multicolumn{10}{|c|}{ Entradas de energia do fluxo externo } \\
\hline \multirow[t]{2}{*}{ Vetor entrada } & $\begin{array}{l}\text { mão de obra } \\
\left(\mathrm{MJ} \cdot \mathrm{h}^{-1}\right)\end{array}$ & $\begin{array}{l}\text { harvester } \\
\left(\mathrm{MJ} \cdot \mathrm{h}^{-1}\right)\end{array}$ & $\begin{array}{l}\text { forwarder } \\
\left(\mathrm{MJ}^{-1} \mathrm{~h}^{-1}\right)\end{array}$ & $\begin{array}{c}\text { feller } \\
\left(\mathrm{MJ} \cdot \mathrm{h}^{-1}\right)\end{array}$ & $\begin{array}{l}\text { clambunk } \\
\left(\mathrm{MJ} \cdot \mathrm{h}^{-1}\right)\end{array}$ & $\begin{array}{l}\text { traçador } \\
\left(\mathrm{MJ} \cdot \mathrm{h}^{-1}\right)\end{array}$ & $\begin{array}{c}\text { carga } \\
\left(\mathrm{MJ} \cdot \mathrm{h}^{-1}\right)\end{array}$ & $\begin{array}{c}\text { transporte } \\
\left(\mathrm{MJ} \cdot \mathrm{h}^{-1}\right)\end{array}$ & $\begin{array}{l}\text { diesel } \\
\left(\mathrm{MJ} .^{-1}\right)\end{array}$ \\
\hline & 2,2 & 45 & 45 & 62,7 & 45 & 61,9 & 46,4 & 41,1 & 38 \\
\hline \multicolumn{10}{|c|}{ Matriz consumo } \\
\hline Mão de obra & 0,0283 & 0,0234 & 0,0116 & 0,0127 & 0,0227 & 0,0175 & 0,1449 & $\left(h \cdot m^{-3}\right)$ & \\
\hline Harvester & 0,0283 & 0 & 0 & 0 & 0 & $\mathbf{0}$ & 0 & $\left(h \cdot m^{-3}\right)$ & \\
\hline Forwarder & 0 & 0,0234 & 0 & 0 & 0 & $\mathbf{0}$ & 0 & $\left(h \cdot m^{-3}\right)$ & \\
\hline Feller buncher & 0 & 0 & 0,0116 & 0 & 0 & 0 & 0 & $\left(h \cdot m^{-3}\right)$ & \\
\hline Clambunk & 0 & 0 & 0 & 0,0127 & 0 & 0 & 0 & $\left(h \cdot m^{-3}\right)$ & \\
\hline Garra & 0 & 0 & 0 & 0 & 0,0227 & 0 & 0 & $\left(h \cdot m^{-3}\right)$ & \\
\hline Carregador & 0 & 0 & 0 & 0 & 0 & 0,0175 & 0 & $\left(h \cdot m^{-3}\right)$ & \\
\hline Caminhão & $\mathbf{0}$ & 0 & 0 & 0 & 0 & 0 & 0,1449 & $\left(h \cdot m^{-3}\right)$ & \\
\hline \multirow[t]{2}{*}{ Óleo diesel } & 0,5048 & 0,3999 & 0,3802 & 0,3113 & 0,3300 & 0,3234 & 0,9404 & $\left(1 . \mathrm{m}^{-3}\right)$ & \\
\hline & harvester & forwarder & feller & clambunk & traçador & carga & transporte & & \\
\hline $\begin{array}{l}\text { Vetor resposta } \\
\qquad\left(\mathrm{MJ} \cdot \mathrm{m}^{-3}\right)\end{array}$ & 20,52 & 16,30 & 15,20 & 12,43 & 14,00 & 13,14 & 42,01 & & \\
\hline
\end{tabular}

Figura 7 - Cálculo matricial do dispêndio energético nas atividades de colheita e transporte

Pela soma dos valores no vetor resposta (Figura 7) obteve-se os seguintes dispêndios de energia em cada sistema estudado como mostra a Tabela 18. 
Tabela 18. Dispêndio energético final das operações em cada sistema de colheita

\begin{tabular}{ccccc}
\hline Sistema & $\begin{array}{c}\text { Colheita } \\
\left.\mathbf{( M J . m}^{-3}\right)\end{array}$ & $\begin{array}{c}\text { Carga } \\
\left(\mathbf{M J . m}^{-3}\right)\end{array}$ & $\begin{array}{c}\text { Transporte } \\
\left(\mathbf{M J . m}^{-3}\right)\end{array}$ & $\begin{array}{c}\text { Total } \\
\left(\mathbf{M J . m}^{-3}\right)\end{array}$ \\
\hline Toras curtas & 36,82 & 13,14 & 42,01 & 91,97 \\
Toras longas & 41,63 & 13,14 & 42,01 & 96,78 \\
\hline
\end{tabular}

Considerando-se o poder calorífico da madeira seca de $19.110 \mathrm{MJ} . \mathrm{t}^{-1}$, os $300 \mathrm{~m}^{3} \cdot \mathrm{ha}^{-1}$ representam uma produção energética de 2.873.250MJ.ha ${ }^{-1}$.

A demanda total de energia das atividades, para os dois sistemas neste estudo, são apresentadas na Tabela 19 a seguir conforme as operações e métodos de cálculo efetuados.

Nota-se a maior demanda de energia na operação de transporte quando comparada às demais e ambas as formass de cálculo.

Tabela 19. Súmula dos dispêndios energéticos $\left(\mathrm{MJ}^{-\mathrm{m}^{-3}}\right)$ das operações conforme o método de cálculo

\begin{tabular}{lcccc}
\hline \multicolumn{1}{c}{ Operações } & \multicolumn{2}{c}{ Toras curtas } & \multicolumn{2}{c}{ Toras longas } \\
& Matricial & Analítico & Matricial & Analítico \\
\hline Preparo do solo & 21,18 & 20,05 & 21,18 & 20,05 \\
Transplante & 22,20 & 22,17 & 22,20 & 22,17 \\
Manejo e condução & 17,76 & 17,77 & 17,76 & 17,77 \\
Colheita & 36,82 & 36,73 & 41,63 & 41,53 \\
Carga & 13,14 & 13,11 & 13,14 & 13,11 \\
Transporte rodoviário & 42,01 & 41,92 & 42,01 & 41,92 \\
\multicolumn{1}{c}{ Total } & 152,11 & 151,75 & 156,92 & 156,55 \\
\hline
\end{tabular}




\section{DISCUSSÃO}

No caso das atividades florestais, os dois métodos de cálculo utilizados apresentaram algumas diferenças. Pelo cálculo matricial ambos os sistemas de colheita apresentaram valores $0,22 \%$ maiores se comparados ao analítico, no entanto essa diferença pode ser atribuída aos arredondamentos em cada operação de cálculo e não implicam em distorções na caracterização de qualquer um dos sistemas de colheita analisados. O método analítico permitiu melhor caracterização de cada sistema ao se considerar os fluxos das entradas de energia (direta e indireta) para cada operação e também melhor detalhamento da demanda energética em função do número de máquinas utilizadas. Embora a sugestão de Sartori \& Basta (1999) tenha sido a utilização do método matricial para efetuar esse tipo de análise, neste estudo o método de equações foi considerado vantajoso, sendo recomendado por explicitar nos resultados a participação de cada fonte podendo-se contabilizar a energia direta pelo uso do combustível, pela atividade humana, pelo uso de mudas e da energia indireta devido à energia agregada nas edificações e nas máquinas utilizadas.

As entradas conforme o fluxo externo de energia, em todas as atividades estudadas, desde a silvicultura até a colheita e transporte foram maiores para a energia direta proveniente de origem fóssil e menores para a atividade humana. Os resultados são similares ao contabilizado por diversos autores (Borjesson, 1996; Serra et al., 1979; Suiter Filho et al., 1982 e Ulbanere, 1988).

As entradas de energia direta devido ao trabalho humano foram da ordem de 0,6\% em todas as atividades, indicando não ser fator de grande influência nos sistemas mecanizados. Macedônio \& Picchioni (1985) e Ulbanere (1998) consideraram que a 
mão de obra tem sua maior limitação nas negociações salariais do que na energia investida. Desta forma sugere-se que em trabalhos cujo enfoque seja contabilizar a influência econômica e energética da mão de obra, deve ser considerada a demanda energética em função do padrão de vida das pessoas, classificadas por classe ou hierarquia do trabalhador como citado por Pimentel \& Pimentel (1996).

Ponderando-se a demanda de energia nas atividades conforme a fonte, ficou claro que a energia direta proveniente da matriz fóssil seja devido ao uso de combustível, de fertilizante ou de agroquímico têm a maior participação na maioria das operações analisadas. Nas atividades de silvicultura o investimento energético foi maior devido ao uso de insumos (fertilizantes, corretivos, formicidas e herbicidas) em função da alta intensidade energética destes. $O$ combustível nessa atividade representou a segunda fonte de maior investimento. Na atividade de colheita e transporte a demanda energética está em grande parte em função apenas do consumo de combustível, não havendo uso de outros insumos.

Neste aspecto, o principal item a ser monitorado ao se buscar subsídios para a redução da intensidade energética no sistema mecanizado será diferenciado para cada atividade. Para a silvicultura deve ser dada maior atenção ao uso de fertilizantes e agroquímicos enquanto que o consumo de combustível é o segundo item a ser monitorado.

$\mathrm{Na}$ atividade de colheita e transporte o componente de maior peso é o óleo diesel, assim como verificado por Athanassiadis et al. (2002), os quais consideraram que aumento do consumo de combustível é inerente ao incremento da mecanização. Em seus estudos a demanda energética das operações de colheita foram $20 \%$ menores do que o verificado na década de 80 para as condições da Suécia. Essa redução foi atribuída à troca do módulo mecanizado composto por três máquinas (feller - buncher, processador e forwarder) pelo módulo composto por duas (harvester e forwarder), auxiliada também pela evolução dos motores diesel quanto à eficiência de combustão.

O fluxo indireto de energia dada pela depreciação energética de máquinas e da infra-estrutura teve, de modo geral, pequena participação na maioria das atividades. No entanto, a atividade de produção de mudas no viveiro apresentou valores semelhantes na 
demanda de energias direta e indireta devido a alta intensidade energética do adubo nitrogenado usado nas mudas e do aço utilizado nas mesas de suporte das bandejas. A energia agregada pela atividade de produção das mudas foi 17,7 vezes maior do que o verificado por Suiter Filho et al. (1982) que contabilizaram apenas o combustível gasto pelas máquinas e 5,1 vezes maior do que o valor considerado por Damen (2001) o qual utilizou a referência de culturas agrícolas da Europa.

Nas atividades de silvicultura, de colheita e de transporte a energia indireta agregada na fabricação, montagem, reparo e manutenção das máquinas e equipamentos não representaram grandes dispêndios do ponto de vista energético. Contudo, segundo Fluck (1985) existe o fluxo de energia devido ao componente assistência técnica cujo valor é difícil de ser mensurado pela análise energética.

Especificamente na colheita a depreciação energética teve uma participação média de $6,4 \%$ da demanda total, não representou ser fator relevante e também não está associado à potência, mas sim em função da massa das máquinas utilizadas devido ao método utilizado de depreciação energética conforme proposto por Doering (1980).

No aspecto tamanho e potência da maquinaria verificou-se que não houve influência na demanda de energia da operação assim como verificado por Bridges \& Smith (1979). A produtividade da máquina foi fator de maior influência na demanda de energia da operação, sendo o volume individual por árvore na colheita florestal o principal fator verificado por Seixas \& Oliveira Junior (2004), ou seja, o padrão da floresta.

Quando considerada as operações de colheita, o sistema de "toras curtas" requereu $55,7 \%$ da demanda energética para o corte e processo enquanto que a operação de extração 44,3\%. No sistema de "toras longas" essa demanda representou 70,1\% para o corte e processo e $29,9 \%$ para a extração. Houve uma melhor distribuição da demanda de energia no primeiro sistema enquanto que no segundo houve uma concentração maior nas operações de corte e processo. Se por um lado o sistema de "toras longas" é mais produtivo, por outro pode representar limitações de ordem ambiental tais como, arrasto de matéria orgânica e danos ao solo. 
Sugere-se estudar a influência do aumento da capacidade de carga do "forwarder" no sistema de "toras curtas" como forma de aumentar sua eficiência energética. Já no sistema de "toras longas" deve-se ponderar a vantagem da maior capacidade operacional versus maior demanda energética e impactos ambientais.

Quando considerada a participação de cada operação nos sistemas de colheita dentro da cadeia produtiva as diferenças são minimizadas, não sendo relevante a diferença entre o sistema de "toras curtas" e o de "toras longas" mostrando haver proporcionalidade entre o investimento energético das operações e produtividade das máquinas, conforme citado por Montheith (1980).

Do ponto de vista tecnológico e de gerenciamento do sistema mecanizado, a energia investida nas operações é proporcional nos dois sistemas quanto à produção de madeira, mas em termos de produtividade e eficiência energética em relação às entradas e saídas existem algumas diferenças sendo, no sistema de "toras curtas" o investimento da energia equivale a $1,59 \%$ da produção energética e no sistema de "toras longas" essa relação é de 1,64\%. Na Finlândia esse investimento varia de 2,5 a 3,0\% da produção energética da floresta conforme relatado por Hakkila (2003).

A atividade de transporte rodoviário neste trabalho foi a de maior demanda de energia, considerando-se que essa atividade também teve a maior participação relativa nas emissões de $\mathrm{CO}_{2}$ como verificado por Karjalainen \& Asikainen (1996) há possibilidade de haver uma relação entre demanda de energia e emissão de gases do efeito estufa.

As diferenças nas emissões de gases pelas máquinas segundo Berg \& Lindholm (2005) variam em função da operação, tecnologia dos motores, da qualidade dos combustíveis e da adequação do projeto das máquinas às operações. Sendo assim, a metodologia da análise energética permitirá a coleta e tratamento dos dados para análise necessária e investigações neste sentido, utilizando-se o ciclo de vida das máquinas e equipamentos conforme a atividade a que são submetidas. Uma inferência que pode ser 
testada de modo prático é a utilização do biodiesel como forma de minimizar as emissões na atividade de colheita e transporte de eucalipto, no entanto deve-se considerar a energia agregada na fabricação do biocombustível, seja óleo vegetal trans esterificado ou óleo residual reciclado.

Nos dois sistemas estudados a demanda total de energia nas operações desde a produção de mudas até o transporte foi semelhante ao encontrado por Berg \& Lindholm (2004) nas condições suecas de 1996 e 1997, ou seja, entre 150 e 200MJ.m³, demonstrando haver similaridade da otimização efetiva da tecnologia utilizada no caso brasileiro com o verificado nos países de maior tradição florestal.

Se considerada apenas a atividade de colheita a demanda de energia nas condições brasileiras foram em média metade daquela calculada para as condições suecas estuda por Athanassiadis et al (2002). A diferença verificada pode indicar uma vantagem comparativa no que se refere ao investimento energético necessário na fase silvicultural da realidade brasileira para a sueca.

Dos trabalhos feitos sobre balanço energético e análise energética no setor florestal, este permitiu utilizar a mesma metodologia para caracterizar diferentes sistemas, independente do módulo mecanizado utilizado no processo.

A colheita e transporte têm grande participação no investimento energético análogo ao investimento econômico. Assim, no controle das operações deve-se levar em conta a produtividade da máquina e o consumo de diesel para que haja a otimização dos recursos energéticos empregados na colheita para qualquer um dos sistemas mecanizados.

A caracterização dos dispêndios de energia foi o primeiro passo da análise a qual possibilitará em estudos posteriores a possível comparação entre sistemas de colheita numa mesma condição conforme o interesse a ser estabelecido, seja na colheita com casca ou sem casca, seja variando-se o número de operações ou de máquinas. 


\section{CONCLUSÕES}

O maior consumo de energia nos sistemas de colheita mecanizada, seja pelo sistema de "toras longas" ou de "toras curtas" foi devido ao fluxo de energia direta proveniente do consumo de combustível, cerca de 93,3\%.

O maior consumo de energia, em todo o processo de produção de madeira de eucalipto, está na operação de transporte rodoviário $41,92 \mathrm{MJ} \cdot \mathrm{m}^{-3}$ seguido pela colheita, $41,53 \mathrm{MJ} . \mathrm{m}^{-3}$ no sistema de toras longas e $36,73 \mathrm{MJ} \cdot \mathrm{m}^{-3}$ no sistema de toras curtas.

Do investimento energético para formar e colher um hectare de eucalipto, a atividade de colheita e transporte consumiu cerca de $60 \%$ do total, em ambos os sistemas de colheita estudados.

A produção energética da madeira de eucalipto considerada neste estudo foi cerca de 62 vezes maior que a energia investida em todo o ciclo produtivo. 
ANEXOS 
Anexo A - Custo de produção de eucalipto (R\$.ha $\left.{ }^{-1}\right)$ ano base 2002

cingस:

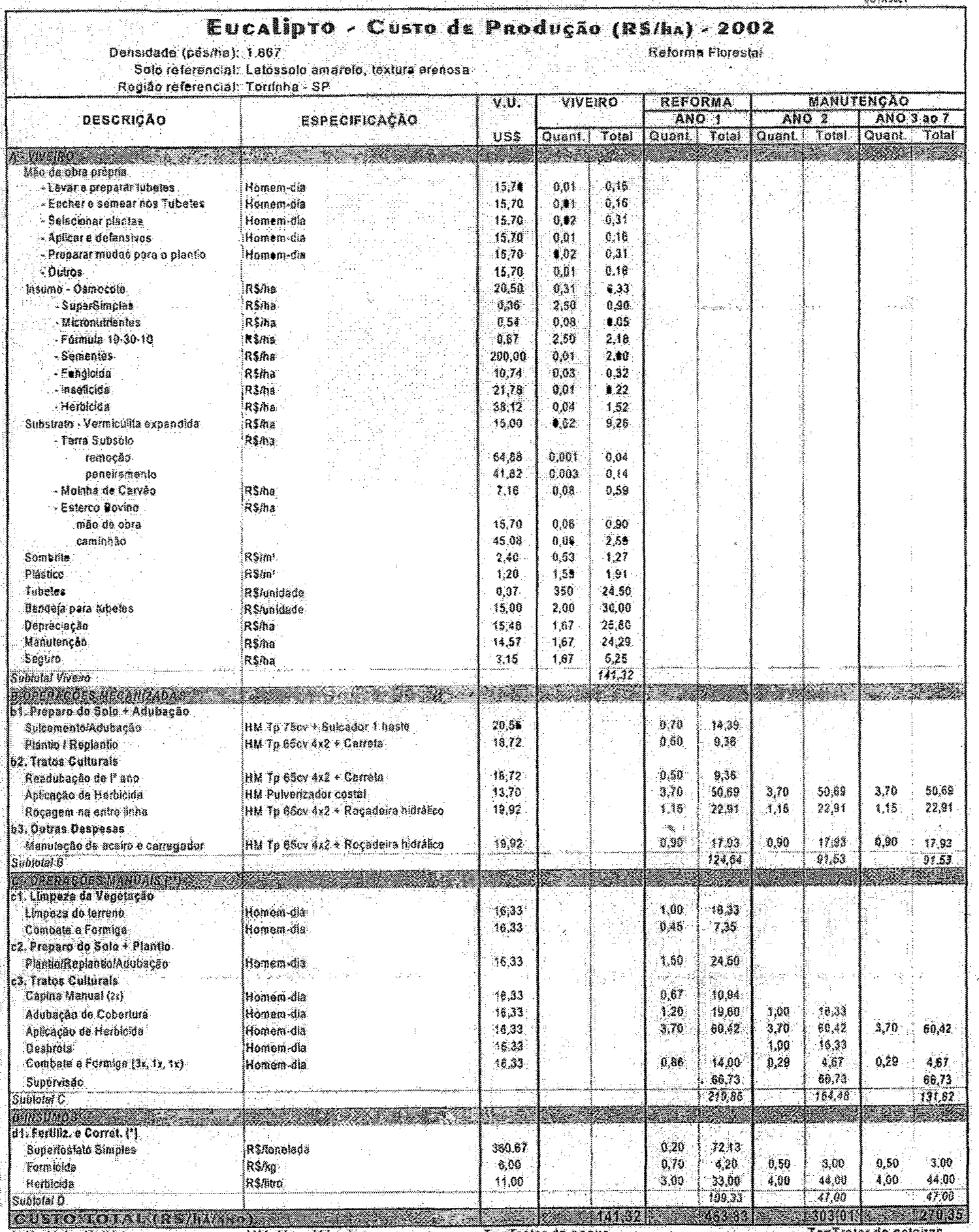

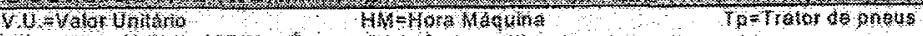

(*) inemos Vatotes Metios te recessato tazer analiss de solo.

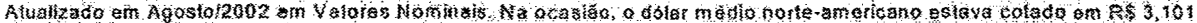

Fonta ENe Consultoria 


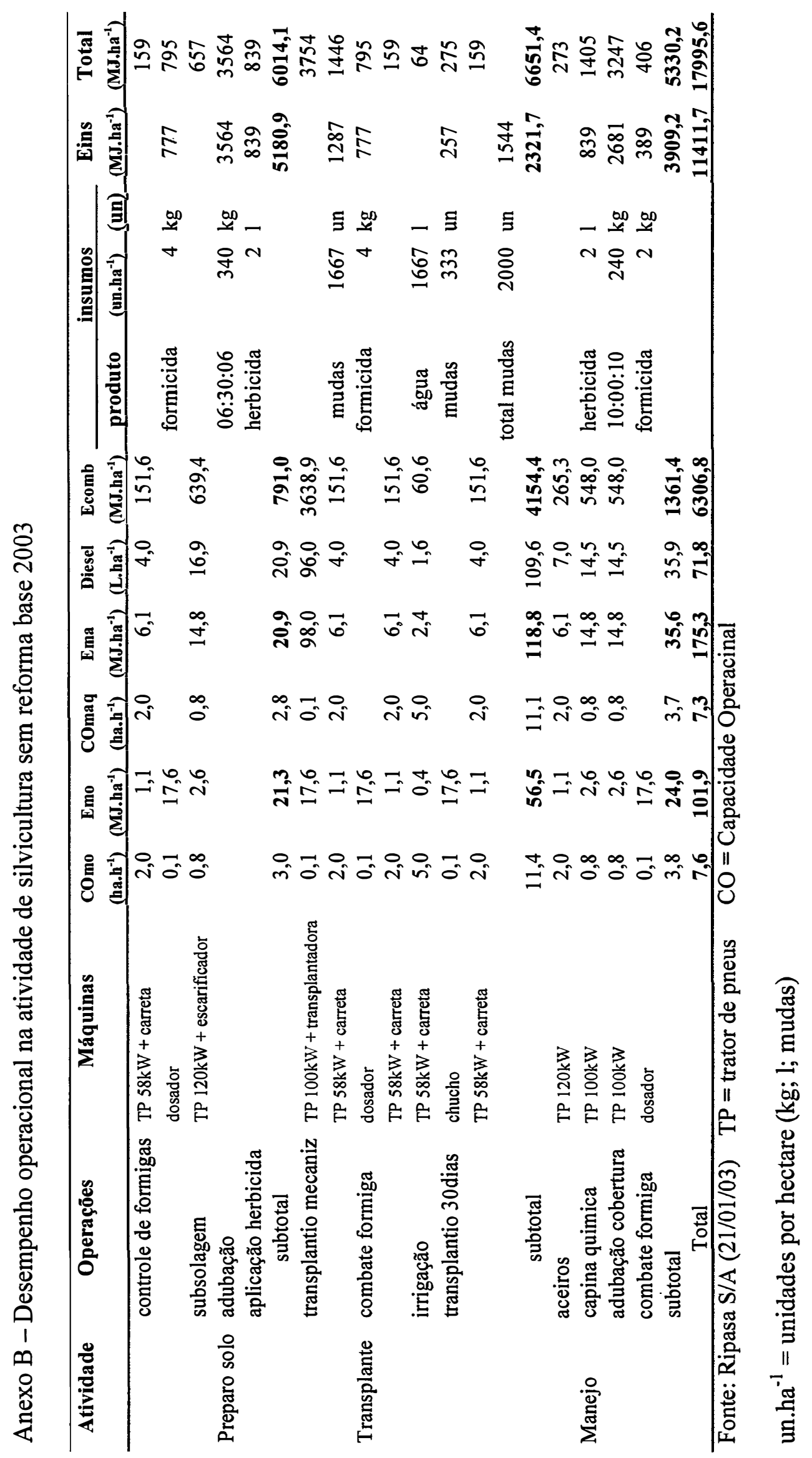


Anexo C - Indicadores de produtividade total da máquina base "harvester" Volvo equipamento 933 (TPM)

\begin{tabular}{|c|c|c|c|c|c|c|c|c|}
\hline Contas & unidade & $\mathrm{P} / \mathrm{R}$ & Jan. & Fev. & Mar. & Abr. & Mai. & Média \\
\hline Árvore média & $\mathrm{m}^{3} \cdot \mathrm{mês}^{-1}$ & Previsto & 0,24 & 0,25 & 0,25 & 0,23 & 0,25 & 0,24 \\
\hline $\begin{array}{c}\text { Dias trabalhados } \\
\text { Operação }\end{array}$ & Dias & Previsto & 23,00 & 24,00 & 26,00 & 24,00 & 26,00 & 24,25 \\
\hline \multirow[t]{2}{*}{ Horas rabalhadas } & h.mês ${ }^{-1}$ & Previsto & 236,60 & 326,40 & 352,59 & 382,86 & 323,00 & 382,22 \\
\hline & & Real & 364,25 & 417,83 & 251,42 & 272,25 & & 326,44 \\
\hline \multirow[t]{2}{*}{ Produtividade } & $\mathrm{m}_{\mathrm{cc}}^{3} \cdot \mathrm{h}^{-1}$ & Previsto & 31,25 & 33,75 & 35,00 & 33,75 & 33,75 & 33,51 \\
\hline & & Real & 39,09 & 34,89 & 33,17 & 33,09 & & 35,36 \\
\hline \multirow[t]{2}{*}{ Óleo Diesel } & $1 . m^{-3}$ & Previsto & 0,50 & 0,50 & 0,50 & 0,50 & 0,50 & 0,50 \\
\hline & & Real & 0,65 & 0,49 & 0,43 & 0,55 & & 0,53 \\
\hline \multirow[t]{2}{*}{$\mathrm{N}^{\mathrm{o}}$ de quebras } & $\mathrm{n}^{0} \cdot \mathrm{mês}^{-1}$ & Previsto & 46,00 & 48,00 & 52,00 & 48,00 & 52,00 & 48,50 \\
\hline & & Real & 51,00 & 36,00 & 31,00 & 41,00 & & 39,75 \\
\hline \multirow[t]{2}{*}{ Duração } & $\mathrm{h}$ & Previsto & 1,05 & 1,05 & 1,05 & 1,05 & 1,05 & 1,05 \\
\hline & & Real & 1,56 & 1,69 & 2,86 & 3,20 & & 2,26 \\
\hline
\end{tabular}

Fonte: Duratex (abr.2003)

Anexo D - Indicadores de produtividade total da máquina base "forwarder" Timberjack 1210 equipamento 333 (TPM)

\begin{tabular}{|c|c|c|c|c|c|c|c|c|}
\hline Contas & Unidade & $\mathrm{P} / \mathrm{R}$ & Jan. & Fev. & Mar. & Abr. & Mai. & Média \\
\hline Árvore média & $\mathrm{m}^{3} \cdot \mathrm{mês}{ }^{-1}$ & Previsto & & & & & & \\
\hline $\begin{array}{c}\text { Dias trabalhados } \\
\text { Operação }\end{array}$ & Dias & Previsto & 25,00 & 24,00 & 26,00 & 24,00 & 26,00 & 24,75 \\
\hline \multirow[t]{2}{*}{ Horas trabalhadas } & h.mês ${ }^{-1}$ & Previsto & 376,74 & 373,81 & 357,14 & 333,00 & 242,86 & 360,17 \\
\hline & & Real & 458,13 & 32,92 & 319,99 & 392,27 & & 300,83 \\
\hline \multirow[t]{2}{*}{ Produtividade } & $\mathrm{m}^{3}{ }_{\mathrm{cc}} \cdot \mathrm{h}^{-1}$ & Previsto & 43,00 & 42,00 & 42,00 & 42,04 & 42,00 & 42,27 \\
\hline & & Real & 43,50 & 45,79 & 42,87 & 41,57 & & 42,76 \\
\hline \multirow[t]{2}{*}{ Óleo Diesel } & $1 . h^{-1}$ & Previsto & 0,25 & 0,25 & 0,25 & 0,25 & 0,25 & 0,25 \\
\hline & & Real & 0,20 & 0,46 & 0,95 & 0,19 & & 0,40 \\
\hline \multirow[t]{2}{*}{$\mathrm{N}^{\mathrm{o}}$ de quebras } & $\mathrm{n}^{0} \cdot$ mês $^{-1}$ & Previsto & 25,00 & 24,00 & 26,00 & 24,00 & 26,00 & 24,75 \\
\hline & & Real & 26,00 & 12,00 & 22,00 & 43,00 & & 25,75 \\
\hline \multirow[t]{2}{*}{ Duração } & $\mathrm{h}$ & Previsto & 3,68 & 1,58 & 1,58 & 1,58 & 1,58 & 2,11 \\
\hline & & Real & 1,58 & 3,81 & 2,84 & 1,18 & & 1,94 \\
\hline
\end{tabular}

Fonte: Duratex (abr.2003) 
Anexo E - Produtividade média das máquinas no sistema de toras longas

Máquina Produtividade Consumo Tempo Padrão Consumo Diesel

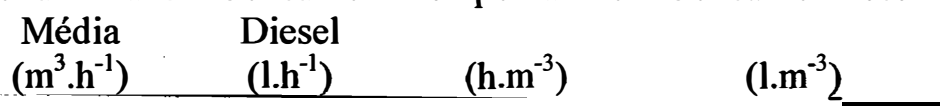

Feller buncher

$\begin{array}{llll}73,8 & 28,78 & 0,0135 & 0,39\end{array}$

Clambunk

Timberjack 1710

Garra traçadora

Timberjack 608B

Fonte: Cenibra (set./2003)

$\begin{array}{llll}68,6 & 26,02 & 0,015 & 0,38\end{array}$

Anexo F - Produtividade média das máquinas no sistema de toras longas

\begin{tabular}{lcccc}
\multicolumn{1}{c}{ Máquina } & $\begin{array}{c}\text { Produtividade } \\
\text { Média } \\
\left(\mathrm{m}^{3} \cdot \mathrm{h}^{-1}\right)\end{array}$ & $\begin{array}{c}\text { Consumo } \\
\text { Diesel } \\
\left(1 . \mathrm{h}^{-1}\right)\end{array}$ & $\begin{array}{c}\text { Tempo Padrão } \\
\left(\mathrm{h} \cdot \mathrm{m}^{-3}\right)\end{array}$ & $\begin{array}{c}\text { Consumo Diesel } \\
\left(1 . \mathrm{m}^{-3}\right)\end{array}$ \\
\hline $\begin{array}{l}\text { Feller buncher } \\
\text { Timberjack 608L }\end{array}$ & 98,65 & 36,77 & 0,0101 & 0,37 \\
$\begin{array}{l}\text { Clambunk } \\
\text { Timberjack 1710 }\end{array}$ & 102,69 & 22,81 & 0,0097 & 0,22 \\
$\begin{array}{l}\text { Garra traçadora } \\
\text { Timberjack 608B }\end{array}$ & 44,0 & 14,52 & 0,0227 & 0,33 \\
\hline
\end{tabular}

Fonte: Votorantin (dez./2004)

Anexo G - Depreciação energética de algumas máquinas, equipamentos e ferramentas

\begin{tabular}{|c|c|c|c|c|c|c|c|c|c|}
\hline Descrição & $\begin{array}{c}\text { massa } \\
(\mathrm{kg})\end{array}$ & $\begin{array}{c}\text { potência } \\
(\mathrm{kW})\end{array}$ & $\begin{array}{l}\text { V.útil } \\
\text { (anos) }\end{array}$ & $\begin{array}{c}\text { uso } \\
\left(\text { h. }^{2} \text { ano }^{-1}\right) \\
\end{array}$ & $\begin{array}{l}\text { contida } \\
\left(\mathrm{MJ} \cdot \mathrm{h}^{-1}\right)\end{array}$ & $\begin{array}{c}\text { fabric } \\
\left(M J \cdot h^{-1}\right)\end{array}$ & $\begin{array}{c}\mathrm{RM} \\
\left(\mathrm{MJ} \cdot \mathrm{h}^{-1}\right)\end{array}$ & $\begin{array}{c}\text { Ajuste } \\
\left(\mathrm{MJ} \cdot \mathrm{h}^{-1}\right)\end{array}$ & $\begin{array}{c}\text { Total } \\
\left(\mathrm{MJ}^{-\mathrm{h}^{-1}}\right)\end{array}$ \\
\hline aplicador de adubo & 2300 & & 5 & 2000 & 14,4 & 2,0 & 5,0 & 13,5 & 18,5 \\
\hline aplicador de herbicida & 2300 & & 5 & 2000 & 14,4 & 2,0 & 5,0 & 13,5 & 18,5 \\
\hline auto carregável & 7200 & 70 & 10 & 4000 & 8,9 & 0,8 & 2,4 & 8,0 & 10,4 \\
\hline automóvel medio & 1800 & 53 & 3 & 1000 & 37,7 & 11,2 & 7,5 & 40,1 & 47,6 \\
\hline caminhão 6x2 & 18000 & 255 & 8 & 4000 & 27,8 & 6,9 & 5,3 & 28,4 & 33,7 \\
\hline caminhão $6 \times 4$ & 22000 & 255 & 8 & 4000 & 34,0 & 8,2 & 6,5 & 34,6 & 41,1 \\
\hline carregador & 27166 & 180 & 10 & 4000 & 33,6 & 9,9 & 10,8 & 35,7 & 46,4 \\
\hline carreta & 1800 & & 10 & 2000 & 5,7 & 16,3 & 5,6 & 18,0 & 23,6 \\
\hline harvester & 19500 & 160 & 5 & 6000 & 32,7 & 9,5 & 10,4 & 34,6 & 45,0 \\
\hline forwarder & 19500 & 160 & 5 & 6000 & 32,7 & 9,5 & 10,4 & 34,6 & 45,0 \\
\hline feller - buncher & 27166 & 180 & 5 & 6000 & 45,5 & 13,2 & 14,5 & 48,2 & 62,7 \\
\hline skidder & 19500 & 160 & 5 & 6000 & 32,7 & 9,5 & 10,4 & 34,6 & 45,0 \\
\hline garra traçadora & 27166 & 180 & 5 & 6000 & 44,8 & 13,2 & 14,3 & 47,6 & 61,9 \\
\hline subsolador & 500 & & 5 & 2000 & 3,1 & 39,7 & 13,2 & 35,2 & 48,4 \\
\hline trator $4 \times 2$ tda & 7200 & 95 & 10 & 3500 & 10,3 & 1,1 & 2,8 & 9,4 & 12,2 \\
\hline trator de esteira & 10000 & 100 & 10 & 2000 & 25,1 & 5,3 & 7,5 & 24,9 & 32,5 \\
\hline trator florestal arraste & 17000 & 120 & 10 & 4000 & 21,4 & 3,7 & 6,2 & 20,5 & 26,7 \\
\hline motosserra & 2 & 3 & 2 & 2000 & 0,03 & 62,2 & 15,4 & 51,0 & 66,4 \\
\hline
\end{tabular}

fonte: adaptado de Doering, 1980. 


\section{REFERÊNCIAS BIBLIOGRÁFICAS}

AGÊNCIA NACIONAL DE ENERGIA ELÉTRICA. Atlas de energia elétrica do Brasil. 2003. www.aneel.gov.br (21 mar. 04).

AMERICAN SOCIETY OF AGRICULTURAL ENGINEERS. Standards, engineering practices and data. St Joseph: 1999.1017p.

ANUÁRIO ESTATÍSTICO ANP, 2000. www.mme.gov.br/estat_anuario00.htm (21 mar. 2004).

ATHANASSIADIS, D.; LIDESTAV, G.; NORDFJELL, T. Energy use and emissions due to the manufacture of a forwarder. Resource, Conservation and Recycling, v.34, p.149-160, 2002.

BENTIVENHA, S.R.P. Mobilização do solo e crescimento inicial do eucalipto em função do tipo de haste subsoladora, profundidade de trabalho e características do solo. Piracicaba, 2001. 60p. Dissertação (Mestrado) - Escola Superior de Agricultura Luiz de Queiroz, Universidade de São Paulo.

BERG, S.; LINDHOLM, E.L. Energy use and environmental impacts of Forest operations in Sweden. Journal of Cleaner Production, v.13, n.1, p.33 - 42, 2004.

BIEWINGA, E.E. Sustainability of energy crops in Europe. Ultrecht: Centre for Agriculture \& Environment, 1996. 26p.

BORJESSON, P. Energy analysis of biomass produtcion and transpotation. Biomass and Bioenergy, v.11, n.4, p.305-318, 1996. 
BRASIL. Ministério de Minas e Energia. Balanço energético nacional. Brasília, 2000. 154p. http://www.mme.gov.br/sen/ben/ben.html (21 mar. 2004).

BRASIL. Ministério de Minas e Energia. Balanço energético nacional. Brasília, 2003. 154p. http://www.mme.gov.br/sen/ben/ben.html (21 mar. 2004).

BRASIL. Ministério de Minas e Energia. Balanço energético nacional. Brasília, 2004. 154p. http://www.mme.gov.br/sen/ben/ben.html (21 mar. 2004).

BRIDGES, T.C.; SMITH, E.M. A method for determining the total energy input for agricultural practices. Transactions of the ASAE, v.22. p.781 - 784, 1979.

BRITO, J.O. Produtividade energética das populações de Eucalyptus aos 2,5 anos de idade implantadas em Jupiá / MS In: SIMPÓSIO SOBRE ENERGIA DA BIOMASSA FLORESTAL, CONVÊNIO CESP / IPEF, São Paulo, 1983. São Paulo: CESP, 1983. p.94 100.

BRITO, J.O. Fuelwood utilization in Brazil. Biomass and Bioenergy, v.12, n.1, p.69-74, 1997.

BRITO, J.O. Um novo contexto para o papel das florestas plantadas. Preços Agrícolas, v.14, n.155, p.4, set.1999.

BRITO, J.O.; BARRICHELO,L.E.G. Aspectos técnicos da utilização da madeira e carvão vegetal como combustíveis. In: SEMINARIO DE ABASTECIMENTO ENERGETICO INDUSTRIAL COM RECURSOS FLORESTAIS, São Paulo, 1982. São Paulo: Coordenadoria da Industria e Comercio, 1982. p.101 - 137.

BRITO, J.O.; BARRICHELO,L.E.G.; COUTO,H.T.Z.; FAZZIO,E.C.M.; CORRADINI,L.; CARRARA,M.A.; MIGLIORINI,A.J. Avaliação das características dos resíduos de exploração florestal do eucalipto para fins energéticos. Circular Técnica IPEF, n.62, p.1-8, ago.1979. 
BRUNO, M.A.C. Conservação de energia na indústria de fertilizantes. São Paulo: IPT, 1985. $487 \mathrm{p}$.

CAMPOS, A.T.; FERREIRA, W.A.; YAMAGUCHI, L.C.T.; RESENDE, H.; ALMEIDA, F.M. Balanço econômico e energético na produção de silagem de milho em sistema intensivo de produção de leite. Engenharia Rural, v.9, n.1, p.1 - 70, jul. 1998.

CARDOSO, M.N.M. Terceirização da colheita com responsabilidade sócio ambiental. In: SEMINÁRIO DE ATUALIZAÇÃO EM SISTEMAS DE COLHEITA DE MADEIRA E TRANSPORTE FLORESTAL, Curitiba, 2004. Anais. Curitiba: UFPR, 2004. p.1 - 26.

CENTRO NACIONAL DE REFERENCIA DA BIOMASSA. A lenha no Brasil. http://infoener.iee.usp.br/scripts/biomassa/br_lenha.asp (21 abr. 2003).

COMPANHIA HIDRO ELÉTRICA DE SÃO FRANCISCO. Geração de energia: fontes alternativas. http://www.chesf.gov.br/ctudo-geracao-fontes.html (13 out. 2003).

DAMEN, K. Future prospects for biofuel production in Brazil. A chain analysis comparison of ethanol from sugarcane and methanol from eucalyptus in São Paulo State. Utrecht: Utrecht University, Department of Science Technology and Society, Copernicus Institute for Sustainable Development and Innovation, 2001. 68p.

DOERING, O.C. Accounting for energy in farm machinery and buildings. In: PIMENTEL, David. (Ed.). Handbook of energy utilization in agriculture. Boca Raton: CRC Press, 1980. $475 \mathrm{p}$.

ENGELSTAD, O.P. Fertilizer technology and use. 3.ed. Madison: Soil Science Society of America, 1985. 107p.

FERREIRA, O.C. Análise exergética da agricultura. Economia \& Energia, v.3, n.12, jan. / fev. 1999. http://www.ecen.com/content/eee12/eeel2p.htm (22 abr. 2003) 
FERREIRA, O.C. Emissões de gases de efeito estufa na produção e no uso do carvão vegetal. Economia \& Energia, v.4, n.20, maio / junho 2000. http://www.ecen.com/eee20/emiscarv.htm (22 abr. 2003).

FNP CONSULTORIA \& COMÉRCIO. Agrianual 2003: anuário de agricultura brasileira. São Paulo, 2003. 360p.

FLUCK, R.C. Energy sequestered in repairs and maintenance of agricultural machinery. Transactions of the ASAE, v.28, n.3, p.738 - 744, May / June, 1985.

GOLDEMBERG, J. Biomassa e energia. In: SIMPÓSIO ENERGIA E BIOMASSA FLORESTAL, Piracicaba, 1979. Anais Piracicaba: Cesp; IPEF, 1979. p.2.

GONÇALVES, J.L.M.; STAPE, J.L.; WICHERT, M.C.P.; GAVA, J.L. Manejo de resíduos vegetais e preparo de solo. In: GONÇALVES, J.L.M. STAPE, J.L. (Ed.) Conservação e cultivo de solos para plantações florestais. Piracicaba: IPEF. 2002. 498p.

GONÇALVES, J.L.M. Perspectivas tecnológicas em áreas florestais manejadas no sistema de cultivo mínimo. IPEF Notícias, p.10 - 11. jul. / ago. 2004.

HAKKILA, P. Developing technology for large: scale production of forest chips; interim report. Tekes, Helsinki: Nacional Technology Agency, 2003. 54p.

HELSEL, Z.R. Energy and alternatives for fertilizer and pesticide use. 1993. http://www.sarep.ucdavis.edu/NEWSLTR/v5n5/sa-12.htm (21 out. 2003).

HERENDEEN, R. Net energy and true subsidies to new energy tecnology. In: MITSCH, W.J.; BOSSERMAN, R.W. Energy and ecological modeling. Amesterdan: Elsevier Scientific, 1981. 839p.

HETZ, E. J. Energy utilization in chilean agriculture. Agricultural Mechanization in Asia, Africa and Latin America, v.23, n.2, p. 52 - 56, 1992. 
INSTITUTO NACIONAL DE METROLOGIA. Sistema internacional de medidas - SI. 8. ed. Rio de Janeiro, 2003. 116p.

KAMIMURA, A. Consumo de lenha no setor residencial: proposta metodológica. NOTA TÉCNICA DNPE/SEM/MME: BEN2002 ANO BASE 2001. PROJETO: PNUD 01/039. http://www.mme.gov.br/sen/ben/BenTab/NovoBen/textos/lenhaBen02.pdf(17 out. 2003).

KARJALAINEN, T.; ASIKAINEN, A. Greenhouse gas emissions from the use of primary energy in Forest operations and long - distance transportation of timber in Finland. Forestry, v.69, n.3, p.215-228. 1996.

KRONKA, F.J.N.; NALON, M.A.; BAITELLO, J.B. Mapeamento e quantificação do reflorestamento no Estado de São Paulo. Florestar Estatístico, v.6, n.14, p.19-27, jan. 2003.

LANÇAS, K.P. Instrumentos para avaliação do desempenho operacional de tratores e variabilidade espacial dos solos. In: GONÇALVES, J.L.M. STAPE, J.L. (Ed.) Conservação e cultivo de solos para plantações florestais. Piracicaba: IPEF, 2002. 498p.

LIMA, W.P. Impacto ambiental do eucalipto. 2.ed. São Paulo: EDUSP, 1993. 302p.

LOFTNESS, R. L. Energy handbook. 2.ed. New York: Van Nostrand Reinhod, 1984. 763p.

LOPES, J.L.W. Produção de mudas de eucalipto em diferentes substratos e lâminas de irrigação. Botucatu, 2004. 100p. Dissertação (Mestrado) - Faculdade de Ciências Agrárias, Universidade Estadual Paulista "Júlio de Mesquita Filho".

MACEDÔNIO, A.C.; PICCHIONI, S.A. Metodologia para o cálculo do consumo de energia fóssil no processo de produção agropecuário. Curitiba: Secretaria da Agricultura, 1985. $45 \mathrm{p}$.

MACHADO, C.C. Colheita florestal. Viçosa: UFV, 2002. 468p. 
MACIEL, A.J.S. Projeto e otimização do sistema de transmissão para um trator agrícola: notas de aula. Campinas: UNICAMP, FEAGRI, 2000.

MAKKONEN, I. Choosing a wheeled shortwood forwarder. FERIC Technical Note, n.136, p.1 $-12,1989$.

MATTSSON, J.E. Energy of Forest machines and in Swedish forestry as a whole. In: SEMINAR ON ENERGY ASPECTS OF THE FOREST INDUSTRIES, Udine, 1979. Proceedings. Oxford: Pergamon Press, 1979. p.321 - 300.

MELLO, R. Rumo a sustentabilidade da produção de cana-de-açúcar em São Paulo: as contas ambientais. Revista de Administração de Empresas, v.40, n.3, p.74 - 82, jul. / set. 2000.

MILAN, M.; MOLIN, J. P. Trator-implemento: dimensionamento, capacidade operacional e custo. In: GONÇALVES, J.L.M. STAPE, J.L. (Ed.) Conservação e cultivo de solos para plantações florestais. Piracicaba: IPEF, 2002, 498p.

MONTEITH, O. Accounting for energy in farm machinery and buildings. In: PIMENTEL, D. (Ed.) Handbook of energy utilization in agriculture. Boca Raton: CRC Press, 1980. 475p.

NOGUEIRA, L.A.H. Produção e processamento de petróleo e gás natural no Brasil: perspectivas e sustentabilidade nos próximos 20 anos. Agência Nacional do Petróleo. In: SUSTENTABILIDADE NA GERAÇÃO E USO DE ENERGIA NO BRASIL, Campinas, 2002. Campinas: UNICAMP, 2002.

PIMENTEL, D. (Ed.) Handbook of energy utilization in agriculture. Boca Raton: CRC Press, 1980. 475p.

PIMENTEL, D.; PIMENTEL, M. Food, energy and society. Colorado: University Press of Colorado, 1996. 297p. 
REDDY, A.K.N., WILLIAMS, R.H., JOHANSSON, T.B. Energy after Rio: prospects and challenges. New York: United Nations Development Program, 1997. 188p.

RIBEIRO, F.A.; RAMOS,G. Desenvolvimento de equipamentos para a utilização em áreas de cultivo mínimo na Ripasa S.A. Celulose e Papel. In: SEMINARIO SOBRE CULTIVO MINIMO NO SOLO EM FLORESTAS, 1, Curitiba, 1995. Anais. Piracicaba: CNPF; IPEF; UNESP; SIF; FUPEF, 1995. p.110 - 116.

SAAB - SCANIA DO BRASIL LTDA. Desempenho. Curitiba, 1998. 62p.

SÃO PAULO (ESTADO). Secretaria de energia, recursos hídricos e saneamento. Balanço energético do Estado de São Paulo 2003: ano base 2002. São Paulo: Cesp, 2003. 206p.

SARTORI, M.M.P.; BASTA, C. Métodos matemáticos para o cálculo energético da produção de cana de açúcar. Energia na Agricultura, v.14, n.1, p.52-68, 1999.

SASAKI,C.M. Força de tração e desempenho operacional de hastes subsoladoras em solos com diferentes texturas e umidade. Piracicaba, 2000. 53p. Dissertação (Mestrado) - Escola Superior de Agricultura "Luiz de Queiroz", Universidade de São Paulo.

SCHOLZ, V.; BERG, W.; KAULFU $\beta$, P. Energy balance of solid biofuels. Journal of Agricultural Engineering Research, v.71, p.263 - 272, 1998.

SEIXAS, F. Avaliação do esforço físico em operadores de motosserra. Série Técnica do IPEF, v.7, n.22, p.1 - 16. jun. 1991.

SEIXAS, F. Potencial de danos dos sistemas de colheita de madeira no solo e nas cepas. Série Técnica do IPEF, n.30, p.63 - 78, abr. 1997.

SEIXAS, F. Compactação da madeira devido à colheita. Piracicaba, 2000. 75p. Tese (Livre Docência) - Escola Superior de Agricultura "Luiz de Queiroz". Universidade de São Paulo. 
SEIXAS, F. Forest engineering conference. Växjö: 2003. (Relatório de Participação no Evento).

SEIXAS, F.; OLIVEIRA JUNIOR, E.D. Compactação do solo devido ao tráfego de máquinas de colheita de madeira. Scentia Florestalis, n.60, p.73 - 87, dez. 2001.

SEIXAS, F.; OLIVEIRA JUNIOR, E.D. Comparativo do custo de composições rodoviárias no transporte de madeira. Piracicaba: IPEF, 2004. 12p. (Relatório Cenibra, 2004).

SERRA, G.E.; GOLDEMBERG, J.; MOREIRA, J.R.; CARVALHO, M.C. Estudo energético de alternativas brasileiras para produção de energia renovável. In: CONVENSION UPADI, Santiago, 1978. p.378- 417 .

SERRA, G.E.; HEEZEN, A.M.; MOREIRA, J.R.; GOLDEMBERG, J. Avaliação da energia investida na fase agrícola de algumas culturas. São Paulo: Ministério da Indústria e Comércio. Secretaria de tecnologia industrial. 1979. 86p. (Relatório final).

SOCIEDADE BRASILEIRA DE SILVICULTURA.2004. http://www.sbs.org.br/estatisticas.htm (26 fev. 2003).

STAPE, J.L. Pesquisa busca maior retorno das áreas de reflorestamento. http://www.ipef.br/servicos/clipping/007-2003.hml (26 fev. 2003).

SUITER FILHO, W.; REZENDE, G.C.; TONINELLO, S.L.; DABÉS, A.D. Considerações sobre o balanço energético de florestas de eucalipto. Silvicultura, v.8, n.28, p.887 - 890, 1982.

ULBANERE, R.C. Análise dos balanços energético e econômico relativa à produção de grãos de milho no Estado de São Paulo. Botucatu, 1988. 127p. Tese (Doutorado) - Faculdade de Ciências Agrárias, Universidade Estadual Paulista “Júlio de Mesquita Filho". 
VOJCIECHOVSKI, G.C.; SCHUCHOVSKI, M.S.; FOLETTO, V.D.F. Interface da colheita com novos plantios. In: SEMINÁRIO DE ATUALIZAÇÃO EM SISTEMAS DE COLHEITA DE MADEIRA E TRANSPORTE FLORESTAL, Curitiba, 2004. Anais. Curitiba: UFPR, 2004. p.395 - 409.

ZANI FILHO, J., BALLONI, E.A., STAPE, J.L. Viveiro de mudas florestais: análise de um sistema operacional atual e perspectivas futuras. IPEF. Circular Técnica, 168. jun. 1989. http://www.ipef.br/publicacoes/ctecnica/nr168.pdf (17 nov. 2004). 
APÊNDICES 
APÊNDICE 1. Fatores de conversão de energia para insumos

\begin{tabular}{|c|c|c|c|c|c|}
\hline insumo & un & GJ kg-1 & insumo & {$[\mathbf{N}]$} & MJ kg ${ }^{-1}$ \\
\hline carvão equivalente & tCE & 29,3 & Nitrogenados & & \\
\hline óleo equivalente & tOE & 45 & $\mathrm{~N}$ & 1,00 & 105 \\
\hline óleo cru & $\mathrm{m}^{3}$ & 36 & uréia & 0,45 & 78 \\
\hline óleo combustível ou diesel & $\mathbf{m}^{3}$ & 37 & Nitrato de amônio & 0,34 & 77 \\
\hline querosene & $\mathrm{m}^{3}$ & 35 & Nitrato de Cálcio & 0,16 & 17 \\
\hline gasolina & $\mathrm{m}^{3}$ & 33 & Amônia anidra & 0,82 & 68 \\
\hline metanol & $\mathrm{m}^{3}$ & 16 & Sulfato de amônio & 0,21 & 22 \\
\hline etanol & $\mathrm{m}^{3}$ & 21 & Nitrato de Potássio & 0,14 & 15 \\
\hline GLP & $\mathbf{t}$ & 45,5 & Fosfatados & {$\left[\mathrm{P}_{2} \mathrm{O}_{5}\right]$} & \\
\hline GNV & $\mathrm{m}^{3}$ & 37 & $\mathrm{P}_{2} \mathrm{O}_{5}$ & 1,00 & 13 \\
\hline lenha $30 \%$ & $\mathbf{t}$ & 7 & super simples & 0,21 & 10 \\
\hline resíduo biomassa seca & $\mathrm{t}$ & 22 & super triplo & 0,48 & 22 \\
\hline cavacos $35 \%$ & $\mathrm{t}$ & 12 & termofosfato & 0,30 & 4 \\
\hline resíduo urbano & $\mathrm{t}$ & 11 & fosfato de rocha & 0,05 & 1 \\
\hline energia elétrica & MWh & 4 & $\mathrm{P}$ & 1,14 & 14 \\
\hline óleo equivalente & $\mathrm{tEP}$ & $5,5 \mathrm{~m}^{3}$ madeira & Potássicos & {$\left[\mathrm{K}_{2} \mathrm{O}\right]$} & \\
\hline \multirow[t]{2}{*}{ madeira } & $\mathrm{m}^{-3}$ & 2,27MWh & $\mathrm{K}_{2} \mathrm{O}$ & 1,00 & 6,7 \\
\hline & & & sulfato de potássio & 0,50 & 3,4 \\
\hline insumo & un & $\mathrm{MJ} \mathrm{um}^{-1}$ & $\mathrm{KCl}$ & 0,60 & 7,2 \\
\hline gasolina & 1 & 42 & sulfato de $\mathrm{K}$ e $\mathrm{Mg}$ & 0,25 & 1,7 \\
\hline diesel & 1 & 48 & Calcário & $\mathrm{PRNT}=70$ & 1,7 \\
\hline madeira dura & $\mathrm{kg}$ & 21 & micronutrientes & & 42,6 \\
\hline eletricidade & $\mathrm{kWh}$ & 13 & inseticida & & 365 \\
\hline aço & $\mathrm{kg}$ & 42 & formicida & & 194 \\
\hline aluminio & $\mathrm{kg}$ & 261 & fungicida & & 308 \\
\hline cimento & $\mathrm{kg}$ & 8,7 & herbicida & & 420 \\
\hline plástico & $\mathrm{kg}$ & 9,5 & mudas & & 0,037 \\
\hline \multirow{2}{*}{ madeira serrada } & $\mathrm{kg}$ & 2,3 & óleo diesel & $\mathrm{MJ}^{-1}$ & 38 \\
\hline & & & óleo hidráulico & $\mathrm{MJ}^{-1}$ & 38 \\
\hline intensidade energética & GJ $R \mathbb{\$}^{-1}$ & 7,72 & gasolina & 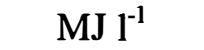 & 34 \\
\hline \multirow[t]{3}{*}{ intensidade energética } & GJ US $\$^{-1}$ & 2,70 & eletricidade & $M J ~ k W \cdot h^{-1}$ & 13 \\
\hline & & & trabalho humano & $\mathrm{MJ} \mathrm{h}^{-1}$ & 2,2 \\
\hline & & & semente & $\mathrm{MJ} \mathrm{kg}^{-1}$ & 2,37 \\
\hline
\end{tabular}


APÊNDICE 2. Depreciação energética das máquinas, equipamentos e ferramentas

$$
\text { Energia contida }\left(\mathbf{E}_{\text {contida }}\right)
$$

MJ.kg-1

Pneus 86

Aço

Trator

Colhedora

50

Tratores

\section{Energia fabricação $\left(\mathbf{E}_{\text {fabric }}\right)$}

MJ.kg-1

14,6

Colhedora cereais

13,0

Implemento de preparo inicial

8,6

Semeadora e cultivadores

8,6

Implemento de preparo periódico

8,4

Pulverizadores

7,4

Enfardadoras

6,3

Coeficiente reparo e manutenção $\left(\mathrm{E}_{\mathrm{RM}}\right)$

$\% \mathrm{Vi}$

Classe 1 ( $4 \times 4$ e esteira)

0,74

Classe 2 ( $4 \times 2$ e motor estacionário)

0,89

Classe 3 (caminhão e patrol)

0,46

Classe 4 (picadores silagem)

0,61

Classe 5 (carretas, equip. montados)

0,76

Classe 6 (aplicador calcário e fertilizante.)

0,91

Classe 7 (grades, enxadas rotativas)

0,93

Residências

Energia de construção

MJ.m ${ }^{-2}$

Oficinas e galpões

Fonte: Doering (1980) 